NOTE TO USERS

This reproduction is the best copy available.

(B)

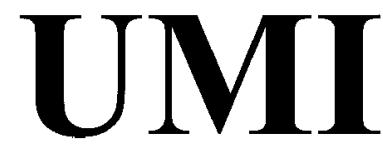




\title{
VOLUMETRIC PROPERTIES OF STONE MASTIC ASPHALT MIXTURES CONTAINING TEAR OFF SHINGLES
}

By

M. Nawaz Panhwer, B.E. (Civil)

\author{
A project \\ Presented to Ryerson University \\ In partial fulfillment of the \\ requirement for the degree of \\ Master of Engineering \\ In the Program of \\ Civil Engineering
}

Toronto, Ontario, Canada, 2004

(C) M.Nawaz Panhwer 2004 
UMI Number: EC52943

\section{INFORMATION TO USERS}

The quality of this reproduction is dependent upon the quality of the copy submitted. Broken or indistinct print, colored or poor quality illustrations and photographs, print bleed-through, substandard margins, and improper alignment can adversely affect reproduction.

In the unlikely event that the author did not send a complete manuscript and there are missing pages, these will be noted. Also, if unauthorized copyright material had to be removed, a note will indicate the deletion.

(®)

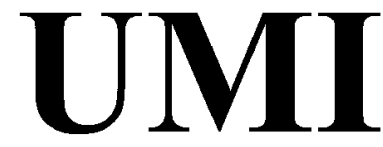

UMI Microform EC52943

Copyright 2008 by ProQuest LLC.

All rights reserved. This microform edition is protected against unauthorized copying under Title 17, United States Code.

ProQuest LLC

789 E. Eisenhower Parkway PO Box 1346

Ann Arbor, MI 48106-1346 


\section{AUTHOR'S DECLARATION}

I hereby declare that I am the sole author of this project.

I authorize Ryerson University to lend this project to other institutions or individuals for the purpose of scholarly research.

M. Nawaz Panhwer

Department of Civil Engineering

Ryerson University

I further authorize Ryerson University to reproduce this project by photocopying or by other means, in total or in part, at the request of other institutions or individuals for the purpose of scholarly research.

M. Nawaz Panhwer

Department of Civil Engineering

Ryerson University 


\section{Borrowers}

Borrowers undertake to give proper credit for any use made of the thesis. Ryerson

University requires the signatures of all persons using or photocopying this project.

Please sign below and give address and date.

\begin{tabular}{|c|c|c|c|}
\hline Name & Signature of Borrower & Address & Date \\
\hline & & & \\
\hline & & & \\
\hline & & & \\
\hline & & & \\
\hline & & & \\
\hline & & & \\
\hline & & & \\
\hline & & & \\
\hline & & & \\
\hline & & & \\
\hline & & & \\
\hline & & & \\
\hline & & & \\
\hline & & & \\
\hline & & & \\
\hline & & & \\
\hline & & & \\
\hline & & & \\
\hline & & & \\
\hline & & & \\
\hline & & & \\
\hline & & & \\
\hline & & & \\
\hline & & & \\
\hline & & & \\
\hline & & & \\
\hline & & & \\
\hline & & & \\
\hline & & & \\
\hline & & & \\
\hline
\end{tabular}




\section{Ryerson University}

\section{School of Graduate studies}

The undersigned certify that they have read, and recommend to the School of Graduate Studies for acceptance, a project entitled "Volumetric Properties of Stone Mastic Asphalt Mixtures Containing Tear-off Shingles"

Submitted in partial fulfillment of the requirements for the degree of Master of Engineering.

\begin{tabular}{|l|r|}
\hline & $\begin{array}{r}\text { Supervisor, } \\
\text { Department of Civil Engineering }\end{array}$ \\
\hline & Department of Civil Engineering \\
\hline & Date \\
\hline
\end{tabular}




\title{
Volumetric Properties of Stone Mastic Asphalt Mixtures Containing Tear Off Shingles
}

\author{
M. Nawaz Panhwer \\ Master of Engineering, 2004 \\ Department of Civil Engineering \\ Ryerson University
}

\begin{abstract}
Stone Mastic Asphalt (SMA) is a tough, stable, rut-resistant mixture that relies on stoneto-stone contact to provide strength and a rich mortar binder to provide durability. The design of an SMA is critical in providing an aggregate grading that will be compatible with the high bitumen content that provides durability without binder drainage. This project investigates the use of tear-off shingles in SMA to produce economic mixtures. The mixture containing shingles were compared to control mixes (without shingles), but with fibers at the same level as those mixtures containing shingles. As per Superpave method of mix design all mixes met the air void ratio at $\mathrm{N}_{\text {(design) }}$ and $\mathrm{N}_{\text {(max). }}$ SMA Mixtures were tested using Marshall Method for stability and flow. Mix design results showed that all required volumetric properties can be achieved with lower binder content if shingles can be added to SMA mixes. The critical property in SMA (the draindown) was controlled and the tensile strength ratio was improved by using tear-off shingles.
\end{abstract}




\section{ACKNOWLEDGMENTS}

I would like to thank my project supervisor Dr. Medhat H. Shehata for his outstanding supervision and guidance. His support, advice and constructive criticism through my graduating have been invaluable.

I would like to thank my Program Director Dr. Mohamed Lachemi and Chair of Civil Department Dr. Said M. Easa for their kind support and cooperation all the time during my stay at Ryerson University.

I am also grateful to my dear wife Rukhsana Panhwer, Brother M. Fayyaz Panhwer and my loving daughter Benazeer and Moomal and dear son Khaleeq Nawaz for their continued support pray and love, I am also grateful to my all colleagues specially Bijal Shah at Ryerson University for their moral and technical support.

Deepest gratitude to my wife and kids, who had to sacrifice their needs and time and supported me to finish my studies.

Finally, I am grateful to the Grace of God for the countless blessings I have received. 


\section{Dedicated \\ To \\ My loving parents}

vii

Reproduced with permission of the copyright owner. Further reproduction prohibited without permission. 


\section{TABLE OF CONTENTS}

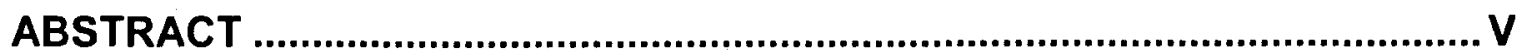

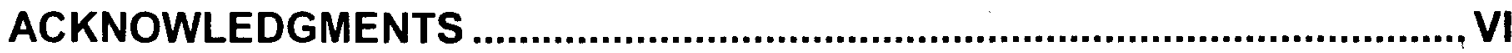

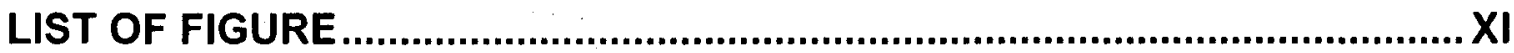

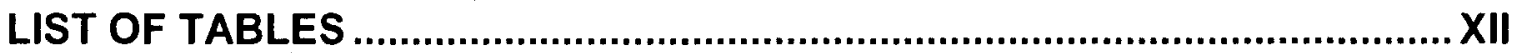

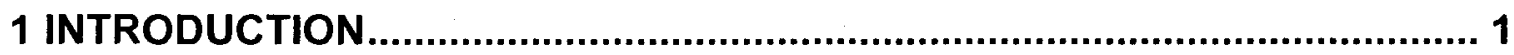

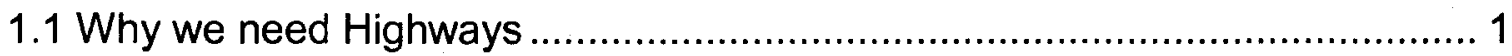

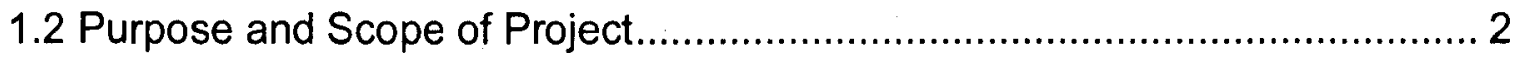

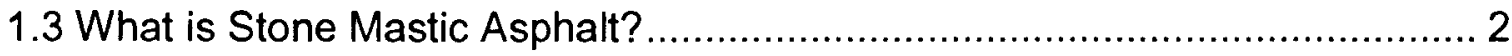

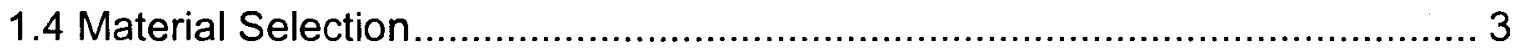

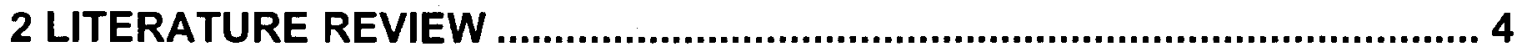

2.1 SMA verses Conventional mixes..................................................................... 4

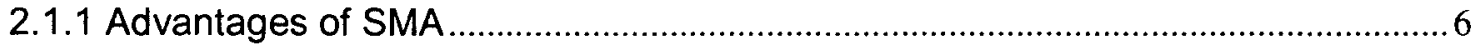

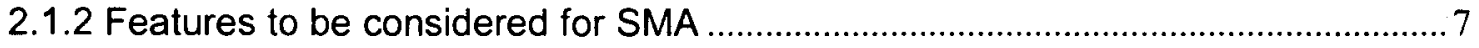

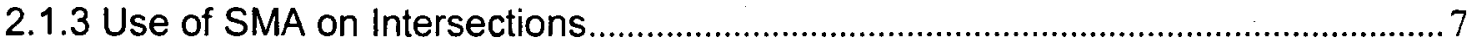

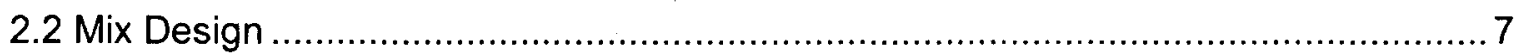

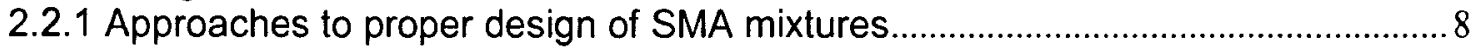

2.2.2 Evaluation of Stone-on-Stone contact in SMA Mix ................................................ 9

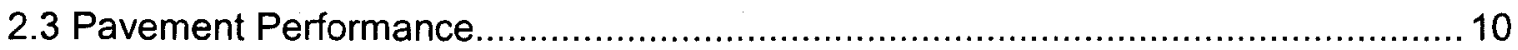

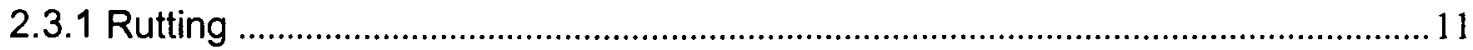

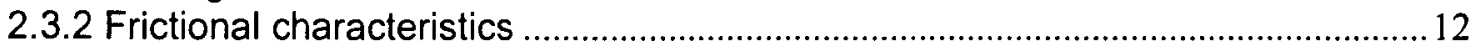

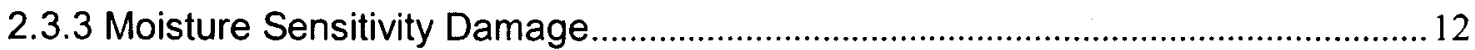

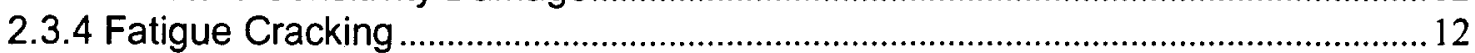

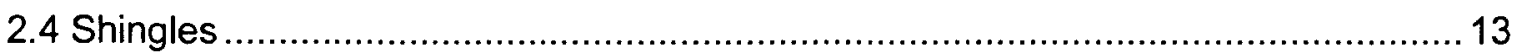

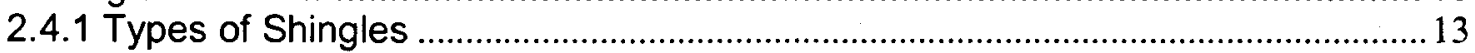

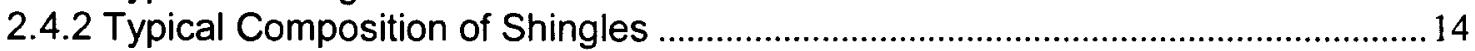

2.4.3 Use of Shingles in Hot mix Asphalt ......................................................................... 14

2.4.4 Use of Reclaimed Asphalt Pavement (RAP) in Hot mix Asphalt ............................. 15

2.4.5 Performance of pavement containing shingles ................................................... 16

viii 


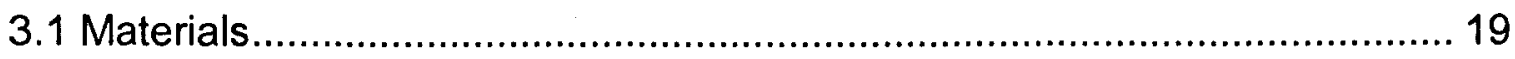

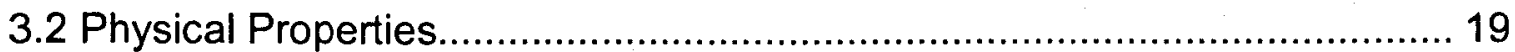

3.2.1 Coarse aggregate angularity (crushed) ............................................... 19

3.2.2 Fine aggregate angularity ....................................................................... 20

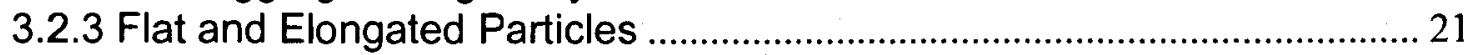

3.2.4 Clay Content (Sand Equivalent) ................................................................ 23

3.2.5 Specific Gravity and Absorption (Coarse Aggregate) …............................. 24

3.2.6 Specific Gravity and Absorption (Fine Aggregate)..................................... 25

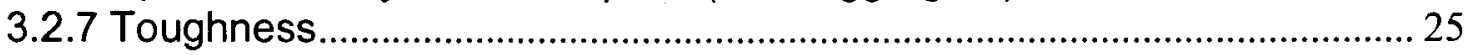

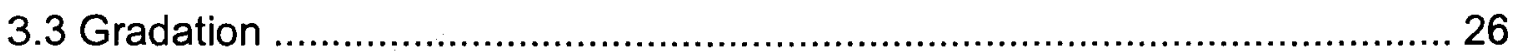

3.3.1 Gradation of Coarse Aggregate ............................................................... 27

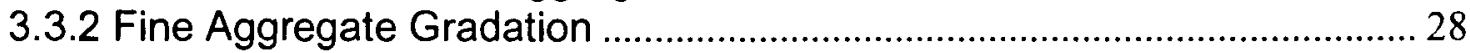

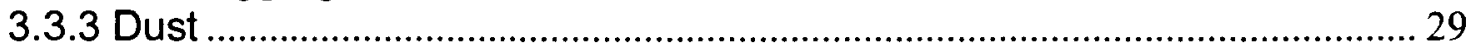

3.3.4 Cement Kiln Dust (CKD) ...................................................................... 30

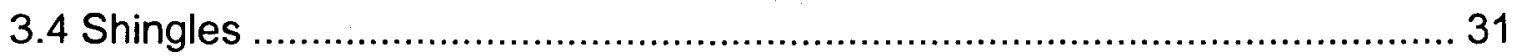

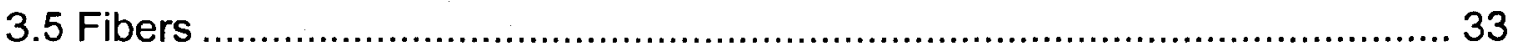

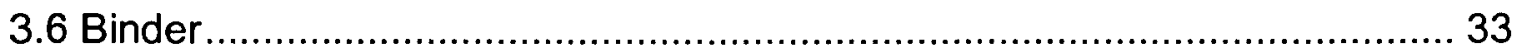

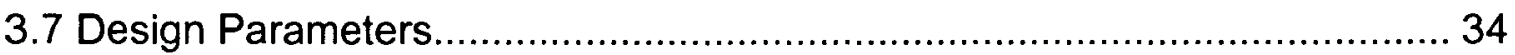

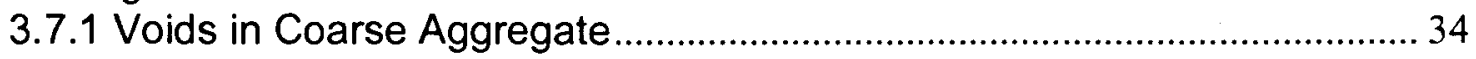

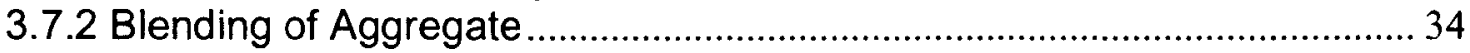

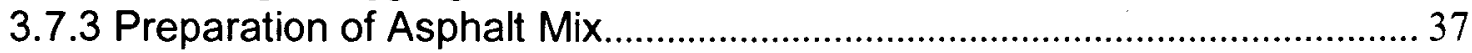

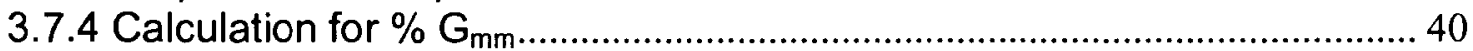

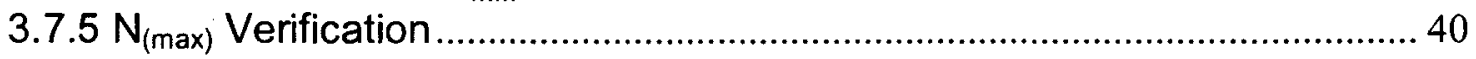

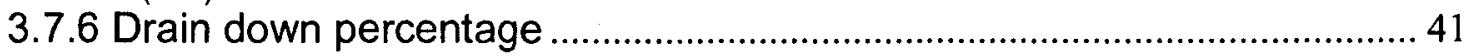

3.7.7 Moisture Sensitivity .................................................................................... 42

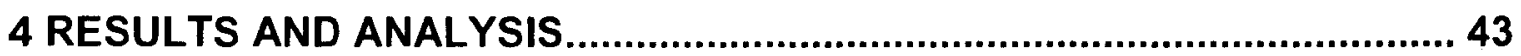

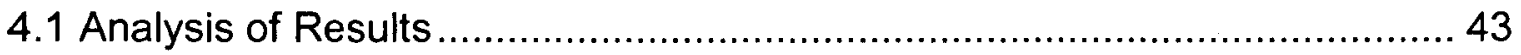

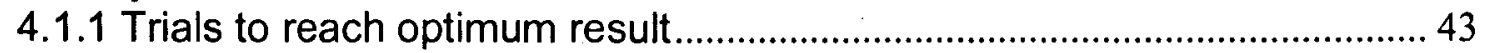

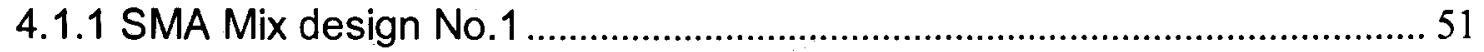

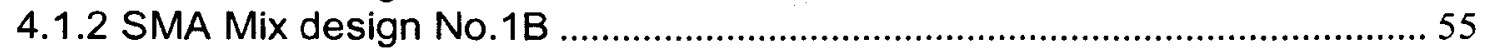

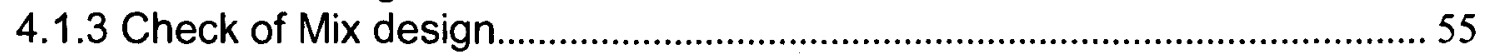

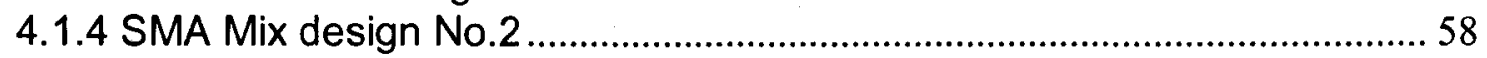

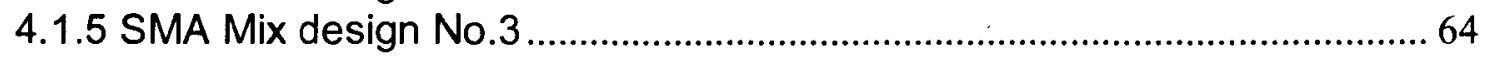

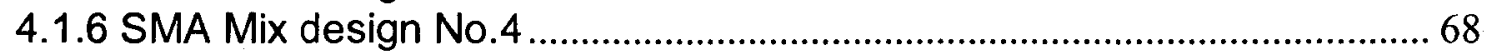

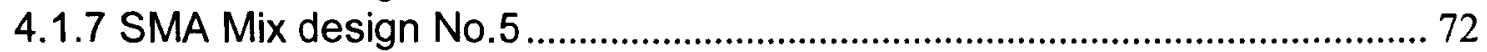

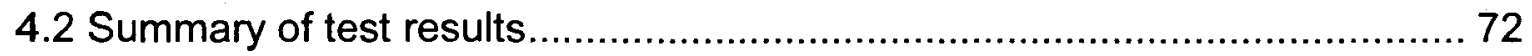

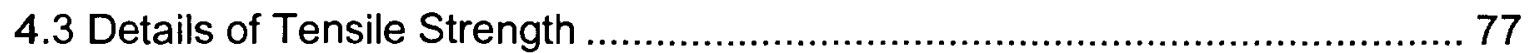


4.4 Discussion of Results

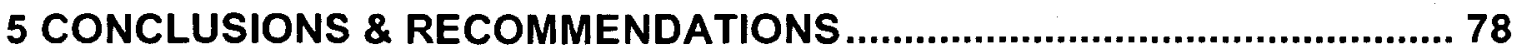

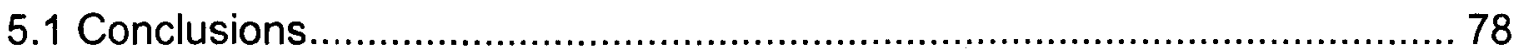

5.2 Recommendations ................................................................... 79

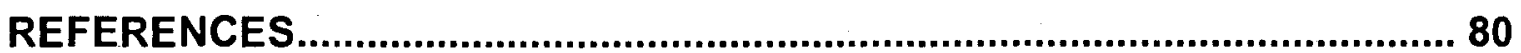

APPENDIX A VOLUMETRIC PROPERTIES OF MIX DESIGNS ................... 82

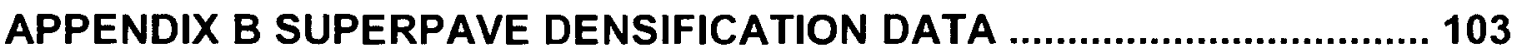

APPENDIX C TENSILE STRENGTH RATIO \& DRAINDOWN .................... 128 


\section{LIST OF FIGURE}

Figure 2.1 Difference between SMA Mix and conventional mix 5

Figure 2.2 Flow Chart of SMA mix design process $\quad 8$

Figure 2.3 Stone-on-stone concept in SMA Mix 10

Figure 2.4 Stability of Aggregates in stone mastic asphalt $\quad 11$

Figure 3.1 Aggregate Angularity test procedure $\quad 21$

Figure 3.2 Flat and elongation measuring caliper 22

Figure 3.3 Sand equivalent cylinder showing clay and sand 23

Figure 3.4 Coarse aggregate's gradation chart 28

Figure 3.5 Fine aggregate's gradation chart 29

Figure 3.6 Dust's gradation chart 30

Figure 3.7 CKD gradation chart 31

Figure 3.8 Tear of Shingle's Gradation Chart 32

Figure 3.9 Aggregate Blending curve for trial blend A 36

Figure 3.10 Superpave Gyratory Compactor

Figure 3.11 Ram pressure and angle during compaction 39

Figure 3.12 Draindown basket assemble $\quad 41$

Figure 4.1 Aggregate blending curves for Trial Blend A $\quad 46$

Figure 4.2 Aggregate blending curves for Trial Blend B 48

Figure 4.3 Aggregate blending curves for Trial Blend C 50

Figure 4.4 Aggregate blending curves for Trial Blend C 53

Figure 4.5 Property curves for SMA mix design No.1 54

Figure 4.6 Extracted materials gradation of SMA mix 1

Figure 4.7 Aggregate blending curves for Trial Blend 1B 60

Figure 4.8 Aggregate blending curves for SMA mix design No.2 62

Figure 4.9 Property curves for SMA mix design No.2 63

Figure 4.10 Aggregate blending curves for SMA mix design No.3 66

Figure 4.11 Property curves for SMA mix design No.3 67

Figure 4.12 Aggregate blending curves for SMA mix design No.4 70

Figure 4.13 Property curves for SMA mix design No.4 71

Figure 4.14 Aggregate blending curves for SMA mix design No.5

Figure 4.15 Property curves for SMA mix design No.5 75 


\section{LIST OF TABLES}

Table 2.1 Typical composition of Shingles 14

Table 3.1 Percentage of Crushed Particles 20

$\begin{array}{ll}\text { Table 3.2 Fine aggregate angularity test result } & 21\end{array}$

Table 3.3 Flat \& Elongation of aggregates $\quad 22$

Table 3.4 Sand Equivalent Result 23

Table 3.5 Specific Gravity of Coarse Aggregate 24

Table 3.6 Specific Gravity of Fine Aggregate 25

Table 3.8 Micro Deval of Coarse Aggregates 26

Table 3.9 Micro Deval of Fine Aggregates 26

Table 3.10 Gradation of Coarse Aggregate $\quad 27$

Table 3.11 Gradation of Fine aggregate $\quad 28$

Table 3.12 Gradation of Dust 29

Table 3.13 Gradation of CKD 30

Table 3.14 Gradation of extracted Shingles $\quad 32$

Table 3.14 Details about fibers 33

Table 3.15 Blending of aggregate For trial blend A 35

Table 3.16 Gyration and traffic details $\quad 39$

Table 4.1 Mix design descriptions $\quad 43$

Table 4.2 Result of different trials of SMA mixture 44

Table 4.3 Aggregate blending for trial blend A 45

$\begin{array}{ll}\text { Table 4.4 Aggregate blending for trial blend B } & 47\end{array}$

Table 4.5 Aggregate blending for trial blend C 49

Table 4.6 Result of SMA mix design No.1 51

Table 4.7 Aggregate blending for SMA mix design No.1 52

Table 4.8 Result of SMA mix design No.1B 55

Table 4.9 Gradation of extracted mixture of SMA Mix No.1 56

Table 4.10 Stability and flow result of SMA Mix No.1 56

Table 4.11 Result of SMA mix design No.2 58

Table 4.12 Aggregate blending for SMA mix design No.1B 59

Table 4.13 Aggregate blending for SMA mix design No.2 61 
Table 4.14 Result of SMA mix design No.3 64

Table 4.15 Aggregate blending for SMA mix design No.3 65

$\begin{array}{ll}\text { Table 4.16Result of SMA mix design No.4 } & 68\end{array}$

Table 4.17 Aggregate blending for SMA mix design No.4 69

Table 4.18 Result of SMA mix design No.5 72

Table 4.19 Aggregate blending for SMA mix design No.5 73

Table 4.20 Summary of test result $\quad 76$

Table 4.21 Details of Tensile strength for SMA mixtures $\quad 77$

Table A.1 Volumetric Properties for trial blend A 83

Table A.2 Volumetric Properties for trial Blend B 84

Table A.3 Volumetric Properties for trial Blend C 85

Table A.4 Volumetric Properties for SMA mix design No.1 86

Table A.5 Volumetric Properties for SMA mix design No.1 87

Table A.6 Volumetric Properties for SMA mix design No.1 88

Table A.7 Marshall Properties for SMA mix design No.1 89

Table A.8 Volumetric Properties for SMA mix design No.1b 90

Table A.9 Volumetric Properties for SMA mix design No.2 91

Table A.10 Volumetric Properties for SMA mix design No.2 92

Table A.11 Volumetric Properties for SMA mix design No.2 93

Table A.12 Volumetric Properties for SMA mix design No.3 94

Table A.13 Volumetric Properties for SMA mix design No.3 95

Table A.14 Volumetric Properties for SMA mix design No.3 96

Table A.15 Volumetric Properties for SMA mix design No.4 97

Table A.16 Volumetric Properties for SMA mix design No.4 98

Table A.17 Volumetric Properties for SMA mix design No.4 , $\quad 99$

Table A.18 Volumetric Properties for SMA mix design No.5 100

Table A.19 Volumetric Properties for SMA mix design No.5 101

Table A.20 Volumetric Properties for SMA mix design No.5 102

Table B.1 Superpave data result for trial Blend A 104

Table B.2 Superpave data result for trial Blend B 105

$\begin{array}{ll}\text { Table B.3 Superpave data result for trial Blend C } & 106\end{array}$

Table B.4 Superpave data result for SMA mix design No.1 107 
Table B.5 Superpave data result for SMA mix design No.1

Table B.6 Superpave data result for SMA mix design No.1

Table B.7 Superpave data Result for Nmax of SMA mix design No.1

Table B.8 Superpave data result for SMA mix design No.1B

Table B.9 Superpave data result for SMA mix design No.2

Table B.10 Superpave data result for SMA mix design No.2

Table B.11 Superpave data result for SMA mix design No.2

Table B.12 Superpave data Result for Nmax of SMA mix design No.2

Table B.13 Superpave data result for SMA mix design No.3

Table B.14 Superpave data result for SMA mix design No.3

Table B.15 Superpave data result for SMA mix design No.3

Table B.16 Superpave data Result for Nmax of SMA mix design No.3

Table B.17 Superpave data result for SMA mix design No.4

Table B.18 Superpave data result for SMA mix design No.4

Table B.19 Superpave data result for SMA mix design No.4

Table B.20 Superpave data Result for Nmax of SMA mix design No.4

Table B.21 Superpave data result for SMA mix design No.5

Table B.22 Superpave data result for SMA mix design No.5

Table B.23 Superpave data result for SMA mix design No.5

Table B.24 Superpave data Result for Nmax of SMA mix design No.5

Table C.1 TSR result for SMA mix design No.1

Table C.2 Drain down result for SMA mix design No.1

Table C.3 TSR result for SMA mix design No.2

Table C. 4 Drain down result for SMA mix design No.2

Table C.5 TSR result for SMA mix design No.3

Table C.6 Drain down result for SMA mix design No.3

Table C.7 TSR result for SMA mix design No.4

Table C. 8 Drain down result for SMA mix design No.4 


\section{Chapter 1}

\section{Introduction}

This project focuses on developing Stone Mastic Asphalt (SMA) Mix designs that comply with the requirements of Ontario Provincial Standards Specifications. The developed mixes intended to reduce the cost of construction and be more durable and stable in terms of rutting and fatigue resistance. At the beginning, it is important to introduce the importance of highways for the development of our society.

\subsection{Why we need Highways}

The need for basic transportation is common to all nations, cultures and times. When ancient Rome ruled the western world, its broad highways crossed the empire, carrying Roman law and civilization to its territories, and local commerce to its markets. Economic growth depends upon roads to connect people and resources, but development of the automobile in the last 100 years has greatly accelerated the worldwide need for good roads. Most modern highways are now built of asphalt concrete and cement concrete, rather than stone and packed earth, and today's paving equipment is powerful, efficient and modern. Good engineering have always been important in building roads. A design engineer considers alignment, gradient, and drainage as well as materials and workmanship in a roadway project. The highways construction depends upon materials and their percentage of mixing. The asphalt concrete mix design is the combination of:

a) Aggregates

b) Asphalt Cement (Binder)

The economical blend of aggregates and asphalt that meet the requirements is called as mix design, in other words the object of mix design is to optimize the properties of mixture with respect to the strength, durability, flexibility, fatigue resistance, skid resistance, permeability and workability.

The importance of formulating a mix design cannot be overstated. Design specifications generally do not name materials, proportions or methods. Rather, a specified road must meet predetermined criteria for the finished pavement; these may include strength, flow, air voids, and most recently, rut-value requirements. The formula is usually worked out 
and tested before hand in an engineering laboratory, so that the completed road will meet the specified criteria when it is constructed. Each criterion of the design is measured with standardized, accepted procedures.

There were two methods of mix design initially but at the present time there are three methods of mix design. There are Hveem method of mix design, Marshall Method of mix design and Superpave method of mix design. The main differences in these three methods are the way of compaction.

Battered by weather and increasing traffic loads, asphalt concrete pavements throughout the world are wearing out much sooner than expected. The result of rough pavements can cause higher maintenance and rehabilitation expenses and more temporary work zones that slow traffic and endanger workers and motorists.

The solution is to build asphalt pavements to hold up better under the weather and traffic conditions found at each project site. That's where the Superpave system comes in.

\subsection{Purpose and Scope of Project}

This project focuses on investigating the potential use of tear off shingles in stone mastic asphalt mixtures. Mix design will be performed according to Superpave method of mix design and to meet the requirements of Ontario Provincial Standard specifications Special Provision No. 313S45M May 2002

\subsection{What is Stone Mastic Asphalt?}

Stone Mastic Asphalt (SMA) is a tough, stable, rut-resistant mixture that relies on stoneto-stone contact to provide strength and a rich mortar binder to provide durability.

Stone Mastic Asphalt technology was developed in Germany and has been used for over 20 years in Europe and Japan. [19] It produces higher quality pavements, which are less susceptible to deterioration and rutting. The technology entails the mixing of aggregate material (sand and stone) with asphalt cement in a form, proportion and manner different from conventional pavement mixes. The major differences are that the asphalt cement content is higher and all aggregates are crushed and graded according to sizes before the mixing operation. Stone mastic asphalt mixes have a higher proportion of coarse 
aggregates (stones) as opposed to fine aggregates (sandy material) than do conventional mixes. Although it is a relatively new mix type in North America over 3 million tons have been placed since 1991. The estimated 20-25 percent increase in cost is more than offset by the increase in life expectancy of the mix, primarily through the decreased rutting and increased durability. SMA is considered to be a premium mix by several state Departments of Transportation for use in areas where high-volume traffic conditions exist and frequent maintenance is costly.

The design of an SMA is critical in providing an aggregate grading that will accept the high bitumen content that provides durability without binder drainage. Conversely an aggregate design that requires a lower binder content to prevent binder drainage will result in a bituminous mixture that will be less durable and have a reduced life. Miller Group constructed the first application of Stone Mastic asphalt in Ontario in 1990 at Miller Avenue Markham Ontario.

\subsection{Material Selection}

Material selection in Superpave method of mix design is more important than other methods. All properties depend on materials selection. The aggregate properties played the integral role in overcoming permanent deformation (rutting). Fatigue cracking and low temperature cracking were less affected by aggregates characteristics. The Marshall and Hveem methods of mix design do not incorporate aggregate criteria into their procedures. In Superpave method of mix design it identifies the two categories of aggregate properties that needed to be used in the Superpave system: physical properties and source properties. Selection of high quality materials for SMA is essential to attain high quality performance and durability.

For binder selection in Superpave method the Performance grade specifications are intended to predict pavement performance. . Determine asphalt properties that will affect the performance of Stone mastic asphalt. Performance should be related to the general pavement behavior, such as rutting, stripping, fatigue cracking, and thermal cracking. 


\section{Chapter 2 \\ Literature Review}

\subsection{SMA verses Conventional mixes}

Stone mastic asphalt (SMA) is gap-graded hot mix asphalt that is designed to increase deformation (rutting) resistance and durability by using of stone-on-stone contact of aggregates. Therefore rut resistance depends on aggregate properties than asphalt binder properties. Since aggregates do not retain as much as asphalt binder under load, this stone-on-stone contact greatly reduces rutting. SMA is generally more expensive than a typical dense-graded HMA (conventional) because it requires more durable aggregates, higher asphalt content and, typically, a modified asphalt binder with fibers. In proper way it should be cost-effective because of its increased rut resistance and improved durability

Contrary to SMA, dense-graded mix is a graded HMA mixture intended for general use. When properly designed and constructed, a dense-graded mix is relatively impermeable. Dense-graded mixes are generally referred to by their nominal maximum aggregate size. They can further be classified as either fine-graded or coarse-graded. Fine-graded mixes have more fine and sand sized particles than coarse-graded mixes.

Figure 1.1 provides the difference between Stone Mastic Asphalt and dense-graded conventional mixtures.

An open-graded HMA mixture is designed to be water permeable (dense-graded and SMA mixes usually are not permeable). Open-graded mixes use only crushed stone (or gravel) and a small percentage of manufactured sands. 
Figure 2.1 Difference between SMA Mix and conventional mix
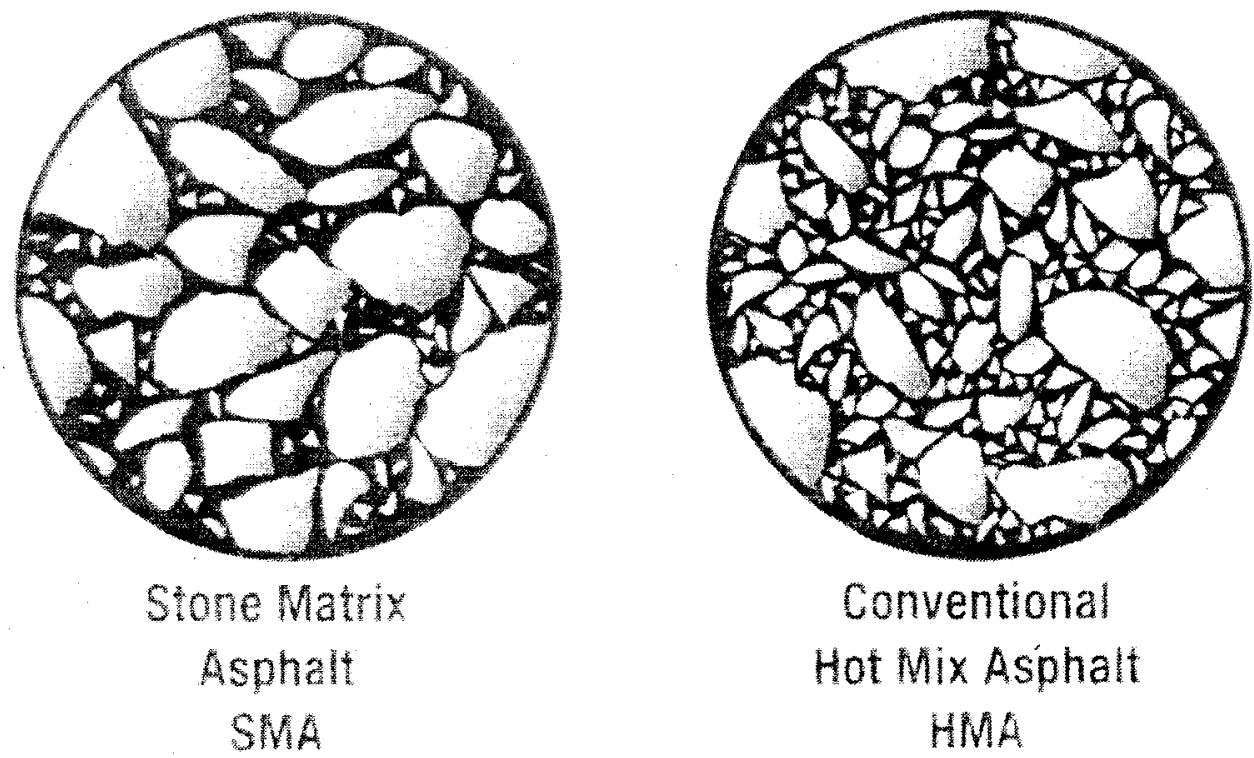

Reference: Designing and Constructing SMA Mixtures, State-of-the-Practice By National Asphalt Pavement Association

An indication of the relative performance of SMA in comparison to conventional surface course hot mix asphalt has been provided by Nordic Asphalt Technologists are given below: [25]

\section{Property of feature}

Shear Resistance

Abrasion resistance

Durability

Load distribution

Cracking resistance

Skid resistance

Water spray

Light reflection

Noise reduction

\section{Ranking of SMA compared to}

\section{Conventional mixes}

Much better

Much better

Much better

Some what less

Better/much better

Better

Equal/better

Better

Equal/better 


\subsubsection{Advantages of SMA}

Mostly SMA benefits include wet weather friction and lower tire noise (due to a coarser surface texture) and less reflective cracking. Mineral fillers and additives are usually added to reduce asphalt binder drain-down during construction. [14] In general SMA have the following advantages:

1. SMA can be considered a standard, high quality, improved performance surface course mix in Ontario.

2. A successful SMA technology has been already developed and used in Ontario.

3. Field performance in Ontario to date shows superior frictional resistance, rutting resistance, fatigue resistance, and noise reduction for SMA surface courses.

4. Life-cycle cost analysis indicates that, despite the higher initial costs for asphalt pavements with SMA surface course, the reduction in deformation and cracking is such that the SMA pavement alternative is very cost effective for major routes with high performance requirements.[25]

5. SMA mixes can be produced and placed using available high quality materials and conventional equipment.

6. Both SMA and Superpave mixtures have been shown to be rut-resistant even when placed on high traffic volume facilities.

7. Much of the observed cracking, especially load-related cracking, appeared to be more related to problems other than mix design or material properties (such as underestimating traffic volumes, or using less than the normal 20-year pavement design life) of the surface courses.

8. SMA mixtures can be expected to last longer than Superpave mixtures before reaching the same condition level.

9. Several of the Superpave and SMA projects are still in excellent condition after being in service for 5 and 9 years, respectively.

10. SMA mixes may significantly reduce the propagation rate of reflective cracking. 


\subsubsection{Features to be considered for SMA}

Following points to be considered for SMA mixtures:

1. Stone mastic asphalt mixes are more expensive in term of cost

2. Adding fibers are very critical in asphalt plants

3. SMA is binder rich, if the use of vibrating roller results in bitumen "flushing up" then operates without vibration. Compaction without vibration means using a larger dead-weight roller to achieve acceptable compaction

4. To allow effective placement and compaction, it is most important that temperature loss is minimized during transport and storage. The high bitumen content of mixtures means that, provided material temperatures remain high enough, compaction is relatively easy

5. Fat spots are one of the most objectionable occurrences in SMA mixtures

6. Because SMA mixes have a high asphalt binder content (on the order of 6 percent), as the mix sits in the HMA storage silos, transport trucks, and after it is placed, the asphalt binder has a tendency to drain off the aggregate and down to the bottom - a phenomenon known as "mix draindown". Adding cellulose or mineral fibers to keep the asphalt binder in place usually combats Mix draindown. Cellulose fibers are typically shredded newspapers and magazines, while mineral fibers are spun from molten rock. A laboratory test is run during mix design to ensure the mix is not subject to excessive draindown. [10]

\subsubsection{Use of SMA on Intersections}

Stone Mastic asphalt has an improved rut resistance and durability. Therefore, SMA is almost exclusively used for surface courses on high volume intersections.

\subsection{Mix Design}

The object of mix design is to optimize the properties of mixture with respect to the strength, durability, flexibility, fatigue resistance, skid resistance, permeability and workability. 
Figure 2.2 Flow Chart for mix

Design of SMA

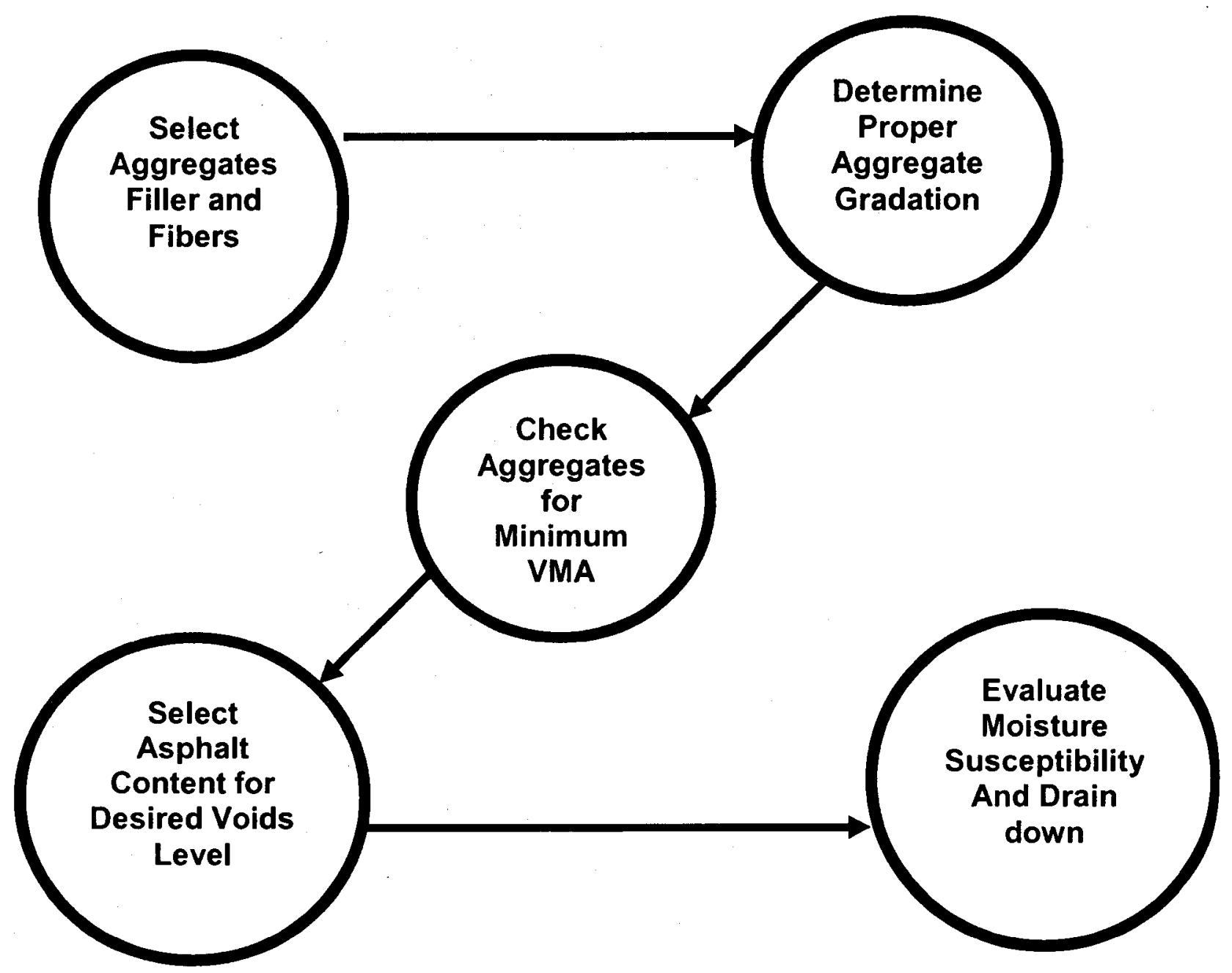

\subsubsection{Approaches to proper design of SMA mixtures}

Proper material selection and mix design to be considered the key factors to succeed with SMA. In the mix design of Stone Mastic Asphalt before 1991, all the agencies were using the Marshall method of mix designing but after that every agency tried to get their mix design with Superpave mix design criteria. [23]

This review covers the Superpave method of mix design. The design process for Stone Mastic Asphalt involves adjusting the grading to accommodate the required binder 
content and voids content rather than the traditional design process for other asphalt mixes, of adjusting the binder content to suit an aggregate gradation. Only crushed aggregates are specified for the Stone Mastic Asphalt to ensure suitable aggregate interlock. The use of natural aggregates containing polished or rounded particles, such as sand, is not permitted. As Stone Mastic Asphalt relies on stone-to-stone contact to provide its strength and a mastic mortar rich in binder, stabilizing additives are needed in the mastic in order to prevent the binder from draining down into the mix. [9]

\subsubsection{Evaluation of Stone-on-Stone contact in SMA Mix}

To obtain optimum resistance to rutting it is believed that stone-on-stone contact in the coarse aggregate portion of the SMA mixture is desired. In the past stone-on-stone contact has been very subjective and has only been evaluated by visual observation from cored samples. Voids in mineral aggregates (VMA) and voids in coarse aggregates (VCA) should be calculated for the compacted samples. Voids in coarse aggregates to be calculated by replacing percent of aggregates in mix (used in VMA calculations) by percent of coarse aggregates in the calculations. To measure the VCA with no fine aggregates, the coarse aggregate was placed in a container and dry rodded to maximum. The aggregates were rodded when the container was filled to one-third, two-thirds and full. The VCA in the dry rodded condition 15 represents the condition at which stone-onstone contact exists. The VMA and VCA at the optimum asphalt content can be then plotted against the percent fines and compared to the VCA for a mix without any fine aggregates. The point at which the VCA in the mixture is equal to the VCA in the dry rodded condition is the point at which it is assumed that stone-on-stone contact exists. [6] In mix design a test for voids in the coarse aggregate (AASHTO T 19) is used to ensure there is stone-on-stone contact. This test method covers the determination of bulk density (unit weight) of aggregate in a compacted or loose condition, and calculated voids between particles in fine, coarse, or mixed aggregates based on same determination. 
Figure2.3 Stone-on-Stone Contact

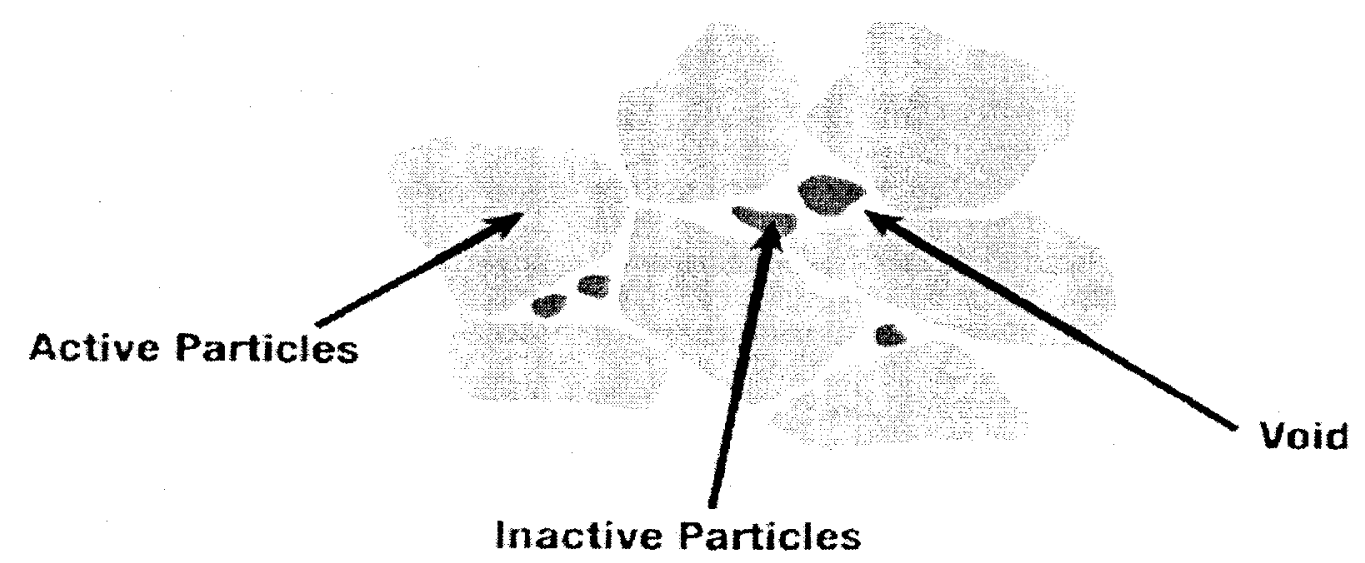

Reference: Designing and Constructing SMA Mixtures, State-of-the-Practice by National Asphalt Pavement Association

\subsection{Pavement Performance}

In mechanistic pavement design the two main criteria of pavement failure are fatigue cracking and permanent deformation (rutting). For permanent deformation the vertical strain at the bottom of the sub base is responsible whereas the horizontal strain between the bituminous and granular layers cause fatigue cracking.

The research showed that the generation of vertical strain between the granular and bituminous layer of samples subjected to wheel-tracking tests. It examines the performance of traditional hot rolled asphalt in comparison to stone mastic asphalt. The process of measuring horizontal longitudinal strain in bituminous mixtures is outlined and results include graphs of strain measurement and rut depths. The improved rutting behavior of SMA compared to conventional mix can be confirmed as well as a correlation of peak strain and rut depth. Stone mastic asphalt shows excellent rutting behavior with wheel tracking rates only $20 \%$ that of conventional mix. [14]

Peak strain values for conventional mixes increase during the test period where as SMA values decrease for considerable amount of time.

Field performance that confirmed the findings of the laboratory comparative characterization completed on representative 1994 SMA, 1995 SMA, HL 1 (PG 64-28) and HL 1 asphalt cores using the Nottingham Asphalt Tester (NAT). The basic 
mechanistic properties of resilient modulus, resistance to rutting and fatigue endurance were tested. On balance, the SMA mixes exhibited the best overall performance and in particular, excellent resistance to fatigue. [25]

Figure 2.4 Stability of aggregates in SMA Mix

\section{Stability in a SMA-Mix}

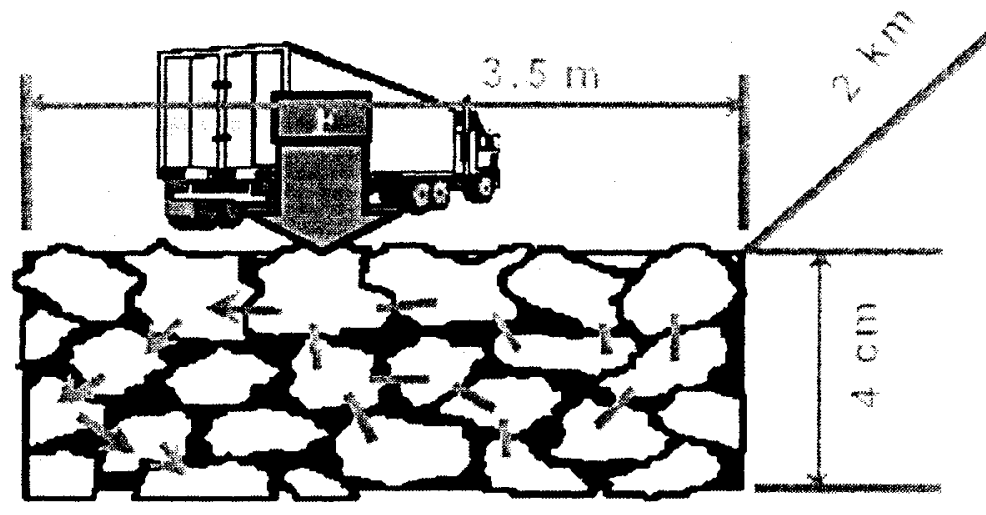

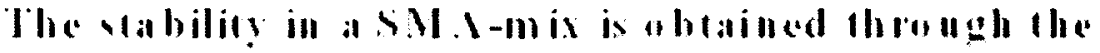
internal firiction in the self-suppurting sune seletun

Reference: SMA Pavements Technology for New Millennium

By Bernd Schneider

\subsubsection{Rutting}

The SMA application on Highway 401 was constructed in 1996, a part of a pavement rehabilitation contract between Highway 25 and Trafalgar Road near Milton. The SMA project was designed to compare the performance of SMA surface mix in the three eastbound lanes with dense friction coarse (DFC) mix placed in the westbound lanes. The project, which is about $11 \mathrm{~km}$ in length (approximately 22,000 tones of mix) and carries about the same level of traffic in both directions, provided an excellent opportunity to collect performance data for the assessment of service life and overall cost effectiveness. Ministry of Transportation Ontario (MTO) conducted ARAN profile measurements in the summer of 1998 and 1999 . The average rut depth is essentially less than $5 \mathrm{~mm}$ with the 
exception of the flushed area at the start of the eastbound driving lane. The amount of rutting is within the expected and normally acceptable range. [8]

\subsubsection{Frictional characteristics}

The pavement frictional characteristics were determined using the ASTM E274 skid trailer for the SMA application on Highway 401 and was part of a pavement rehabilitation contract between Highway 25 and Trafalgar Road near Milton. The data shows an improvement in frictional characteristics for both the SMA and DFC surfaces. Measured SN100 (at a speed of $100 \mathrm{~km} / \mathrm{hr}$ ) values below 30 for Lane 3 reflect the intermittent flushing in the SMA at the start of the eastbound driving lane. The overall 1999 data is significantly lower than the 1997 survey data partly as a result of the corresponding temperature differences at the time of testing. The average temperature at the time of testing was $0^{\circ} \mathrm{C}$, while in 1999 the temperature at the time of testing varied from $14^{\circ} \mathrm{C}$ to $18^{\circ} \mathrm{C}$. Differences in temperature of this magnitude have a significant impact on frictional properties. [8]

\subsubsection{Moisture Sensitivity Damage}

The research found that the increase in asphalt stiffness, related to the application of certain additives or aging, is associated to an increase in mechanical strength (indirect tensile and compressive) and retained strength (moisture damage resistance). There is no evidence of aggregate - asphalt binder adhesion being diminished as asphalt becomes stiffer (expected since stiffer binders are supposed to be easier to detach by water); on the contrary, the fact of retained compressive strength growing faster than retained indirect tensile strength, as the asphalt becomes stiffer, suggests the possibility of an improved aggregate - asphalt binder adhesion through aging. [20]

\subsubsection{Fatigue Cracking}

Stone Mastic Asphalt mixes have performed very well in resisting rutting. Not enough research was performed on fatigue resistance of SMA. The use of cellulose fibers in asphalt mixes has generally been limited to gap graded mixtures such as Stone Mastic 
Asphalt and Open Graded Friction Courses and they are used only to minimize the draindown of asphalt. In the enhancement of resistance to fatigue cracking, $150 \mathrm{~mm}$ by $50 \mathrm{~mm}$ thick cylindrical specimens were prepared and tested at $20^{\circ} \mathrm{C}$ with various proportions of cellulose oil palm fibers. The specimens were loaded at a constant deformation rate of 5 mm per minute of vertical ram movement until failure. The load, deformations, crack initiation and propagation were measured and analyzed. The research showed remarkable enhancement in the fatigue resistance, for a fiber range of 0.6 percent by weight of total $\operatorname{mix} .[22]$

\subsection{Shingles}

Roofing shingles are unlike other by-product or secondary materials in that they contain fine aggregate, mineral filler and asphalt cement

\subsubsection{Types of Shingles}

There are two types of roofing shingle. They are referred as tear-off roofing shingles, and manufactured shingle, also called prompt roofing shingle scrap. Tear-off roofing shingles are generated during the demolition or replacement of existing roofs. Roofing shingle tabs are generated when new asphalt shingles are trimmed during production to the required physical dimensions. The quality of tear-off roofing shingles can be quite variable.[1]

Roofing shingles are produced by collecting either organic felt produced from cellulose fibers, or glass felt produced from glass fibers, with a hot saturant asphalt, which is subsequently coated on both sides with more asphalt and finally surfaced with mineral granules. Most roofing shingles are products of the organic felt type.Both saturant and coating asphalts are produced by "blowing", a process in which air is bubbled through molten asphalt flux. The heat and oxygen act to change the characteristics of the asphalt (makes it stiffer)

The largest component of roofing shingles (60 to 70 percent by mass) is the mineral material. There are several different types in each shingle. They can include ceramic 
granules (comprising crushed rock particles, typically trap rock, coated with colored, ceramic oxides), lap granules (coal slag ground to roughly the same size as the ceramic granules), backsurfacer sand (washed, natural sand used in small quantities to keep packaged shingles from sticking together), and asphalt stabilizer (powdered limestone that is mixed into the asphalt).[1]

\subsubsection{Typical Composition of Shingles}

Table 2.1 shows the typical composition of shingles[1]

\begin{tabular}{|c|c|c|}
\hline Component & Organic Shingles & Fiberglass shingles \\
\hline Asphalt & $30-35 \%$ & $15-20 \%$ \\
\hline Cellulose Fibers & $12-15 \%$ & $12-15 \%$ \\
\hline Felt & $5-15 \%$ & $5-15 \%$ \\
\hline Mineral Filler & $10-20 \%$ & $15-20 \%$ \\
\hline Minerals Granules & $30-50 \%$ & $30-50 \%$ \\
\hline
\end{tabular}

\subsubsection{Use of Shingles in Hot mix Asphalt}

Laboratory studies undertaken during the 1980's suggest that asphalt mixtures containing roofing shingle scrap could show mix design properties similar to that of conventional asphalt mixtures. By using of roofing shingle scrap in hot mix asphalt pavements began in 1990 with trial sections placed in Minnesota. Since then, interest in the use of asphalt paving mixtures containing roofing shingle scrap has increased, with additional studies and trials in Minnesota, Indiana, Illinois, Missouri, New Jersey, and Ontario, Canada. [16]

Typical addition rates for roofing shingle scrap in hot mix asphalt have ranged from 3 to 6 percent (by mass). Evaluations of a New Jersey trial pavement section after a few years of service have indicated that performance similar to conventional hot mix asphalt pavements can be expected, with no significant differences in rut depth, cracking, or skid resistance. [4] 


\subsubsection{Use of Reclaimed Asphalt Pavement (RAP) in Hot mix Asphalt}

RAP is essentially old pavement that is reclaimed for use. In its most common form, it is collected in loose granular form as a byproduct of pavement rehabilitation or reconstruction. RAP can be used in a variety of ways such as:

- As an addition to regular HMA.

- As an aggregate in cold-mix asphalt.

- As a granular base course when pulverized.

- As a fill or embankment material.

RAP is viable replacement for virgin aggregate. With depleting natural resources municipalities should consider RAP as an alternative product. Aggregates in older pavements contain some of the best materials available today.

Research carried out by Little et al 1981, Meyers et al 1983, and Kandhal et al 1994 has indicated that the structural performance of recycled mixes is equal and in some instances better than that of the conventional mixes.

The properties of the recycled mixture are believed to be mainly influenced by the aged reclaimed asphalt pavement (RAP) binder properties and the amount of RAP in the mixture. Some mixtures prepared from the recycled binder blends generally age at a slower rate than virgin mixtures. This may be due to the fact that the RAP binder has already undergone oxidation which tends to retard the rate of hardening, have indicated that the recycled mixtures withstood the action of water better than the virgin mixtures.

It is also shown that the durability of recycled asphalt concrete mixtures is greater than that of the conventional mixtures. [3]

According to Georgia Department of Transportation specification the RAP binder, when blended with virgin asphalt cement, should give a viscosity between 6,000 poises to 16,000 poises after the thin film oven test. [21]

The mix design requirements for Superpave mixtures containing RAP are given below: 
1. General Mix design requirements remain unchanged for Superpave mixtures containing RAP. Requirements for aggregate properties, gradation and volumetric properties should be met by the blend of virgin and reclaimed materials.

2. The gradation of aggregate in the RAP should be used in calculation of the mix gradation. RAP is treated like a stockpile of aggregate during this analysis. Aggregate consensus properties may be run on the individual RAP aggregate stockpile at the agency's discretion. While fine aggregate angularity, sand equivalency, and flat and elongated particles might not be measured on the individual RAP aggregate stockpile, some amount of RAP aggregate will need to be extracted, combined with the total aggregate blend and tested for compliance with aggregate consensus properties.

3. The percentage of asphalt binder in the RAP should be considered when determining the trial asphalt content. Asphalt binder content of the total mixture for mix batching includes virgin and reclaimed asphalt binder. [11]

\subsubsection{Performance of pavement containing shingles}

A number of demonstration projects have been completed using manufactured shingle modifier hot- mix asphalt, covering a broad range of asphalt concrete types and traffic (loading) conditions. The most significant of these are Highway 86 in Waterloo (1995, Ontario Ministry of Transportation) and Sheppard Avenue (1996, Toronto Transportation). These asphalt pavements are being monitored for surface condition (durability), thermal cracking and rutting performance. The performance of these pavements has been most favorable, confirming the laboratory evaluations of manufactured shingle modifier and control section asphalt cores in the Nottingham Asphalt Tester. No problems were encountered during shingles production, placement and compaction. [26]

It was shown that up to $5 \%$, by weight of mixture, of manufacturing waste roofing shingles could be used in asphalt concrete with a minimum impact on the properties of 
the mixture. At a level of $7.5 \%$, a noticeable hardening of the mixture occurs, and this might be detrimental to pavement performance. [4]

Manufactured roofing shingle waste can be incorporated successfully into hot-mix asphalt (HMA), and that roofing shingle modified mixes show less temperature susceptibility than mixes without shingles. Significant savings in the use of asphalt binder can be made since shingles are made of $40-50 \%$ asphalt binder. The properties of HMA are affected mainly because of the presence of asphalt and fiber in the shingles.

Mallick and Mogawen in 2000 recommended that tensile properties of shingle-modified mixes must be determined for evaluation of use of waste shingle in HMA. The authors also showed that the effect on the properties of HMA is dependent on the amount of shingles used, and the effect on tensile strength can get reversed at higher percentage of shingles. [15]

The results from Minnesota Department of Transportation's report show that the use of manufactured waste shingles in HMA does not cause a significant difference in the quality of the HMA. Actually, the rutting resistance is improved by using manufactured waste shingles. Standard deviations of test results for mixes with shingles are low, indicating consistency in the quality of the shingles. Since the mixes with shingles were prepared with less asphalt binder than the control mixes, the results also show that the shingles contribute a significant amount of asphalt binder to the mix, and hence, using 5 $\%$ shingles, the amount of asphalt can be reduced significantly. The author recommended for conducting a field evaluation of use of shingles in HMA. As $3 \%$ shingles does not result in significant savings, it is recommended that test sections with $5 \%$ shingles and control mix be constructed and evaluated for performance. [13]

Waste roofing shingles can be used in HMA in the same way as recycled asphalt pavement (RAP) material, and that significant savings in amount of asphalt binder can be made. Experimental results showed that high temperature rutting resistance can be improved by the addition of shingles in HMA. [12]

It has been concluded from field projects that the use of shingles in HMA can provide excellent performance and result in significant savings by reducing the amount of virgin 
asphalt binder required in HMA. They also concluded that shingle modified mixes are as resistant to moisture as are unmodified mixes, and that a slight increase in hardness of binder of the mix, resulting from the binder in the shingles did not have any adverse effect on low temperature properties of the HMA. Based on the results of laboratory and field study, the authors recommended the use of waste shingles in HMA in the state of Minnesota. [18]

Creep compliance analyses led the researchers to conclude that deformation was reduced when shingles were added to a mix prepared with softer (120/150 penetration) asphalt, but that the opposite was true when shingles were added to mixtures using the harder (85/100 penetration) asphalt. The performance of the shingle-containing SMA was equivalent to the control SMA. [16]

Use of manufactured shingle waste resulted in a less temperature susceptible asphalt mixture. The mixture stiffness was increased when the shingle content exceeded five percent by weight of the aggregate. The roofing waste mixtures for the SMA experiment had similar stiffness to that found for the cellulose fiber control mixture. [9] In general previous work concluded that:

- Use of manufactured shingle waste did not significantly change the moisture susceptibility of the conventional dense-graded mixtures.

- Samples containing tear off material had increased susceptibility to moisture damage.

- Manufactured roofing waste seemed to actually improve the resistance to water damage in the SMA mixtures.

- Tensile strengths at low temperatures decreased with increasing roofing waste content.

- Mixtures made with the tear off material showed a decrease in strain capacity with increased shingle content, implying that this material will be more brittle at cold temperatures. [24] 


\section{Chapter 3 \\ Materials \& Experimental Details}

\subsection{Materials}

Coarse aggregates were selected from MRT quarry located at Havelock, Ontario, and washed screening as fine aggregates from same quarry. The dust is used to accommodate as filler from dust collector of any asphalt plant, which was collected from Miller Group's Asphalt plant in Whitby Ontario. The Superpave mix design system integrates material selection and depends upon the projects climate and design traffic. The selection of aggregates materials depends upon the following items:

\subsection{Physical Properties}

The physical properties of the aggregates used in this study are determined in accordance with Superpave design guidelines. Those properties which achieve high performance and must qualify various levels of depending on the traffic volume and position within the pavement, high traffic levels and surface mixtures require more strict values for physical properties. These properties identified in Superpave are:

\subsubsection{Coarse aggregate angularity (crushed)}

This property ensures a high degree of aggregate internal friction and rutting resistance. It is defined as the percentage (by mass) of aggregates larger than $4.75 \mathrm{~mm}$ with one or more fractured faces. It gives the required minimum values for coarse aggregate angularity as a function of traffic volume and position within the pavement. The percent crushed particles details are given in Table 3.1 According to OPSS \# LS-607 60-80\% particles should be crushed. 
Table 3.1 Crushed Aggregate

\begin{tabular}{|c|c|c|c|}
\hline Fraction & $\begin{array}{c}\text { Total } \\
\text { Mass of } \\
\text { Particles }\end{array}$ & $\begin{array}{c}\text { Mass of } \\
\text { Uncrushed } \\
\text { Particles }\end{array}$ & $\begin{array}{c}\text { Mass of } \\
\text { Crushed }\end{array}$ \\
\hline $13.2-9.5 \mathrm{~mm}$ & 1029 & 22 & 1007 \\
\hline $9.5-6.7 \mathrm{~mm}$ & 609 & 12 & 597 \\
\hline $6.7-4.75 \mathrm{~mm}$ & 428 & 9 & 419 \\
\hline $\begin{array}{c}\text { Total Particles } \\
\text { \% of Each } \\
\text { fraction }\end{array}$ & 2066 & 43 & 2023 \\
\hline
\end{tabular}

\subsubsection{Fine aggregate angularity}

The angularity of fine aggregates is determined by measuring the amount of voids in a certain volume of aggregates in a loose condition. This void content provides an indication of the aggregate angularity, the higher the voids, the high angularity of sand.

For testing take a sample of fine, washed and dried aggregate poured into a small calibrated cylinder through a standard funnel, the mass of fine aggregate $(W)$ in the filled cylinder of known volume (V), the void content can be calculated as the difference between the cylinder volume and fine aggregate volume collected in cylinder.

The bulk specific gravity $\left(\mathbf{G}_{\mathbf{s b}}\right)$ is used to determine the fine aggregate volume. See figure 3.1[23] 
Figure 3.1 Fine Aggregate angularity testing system

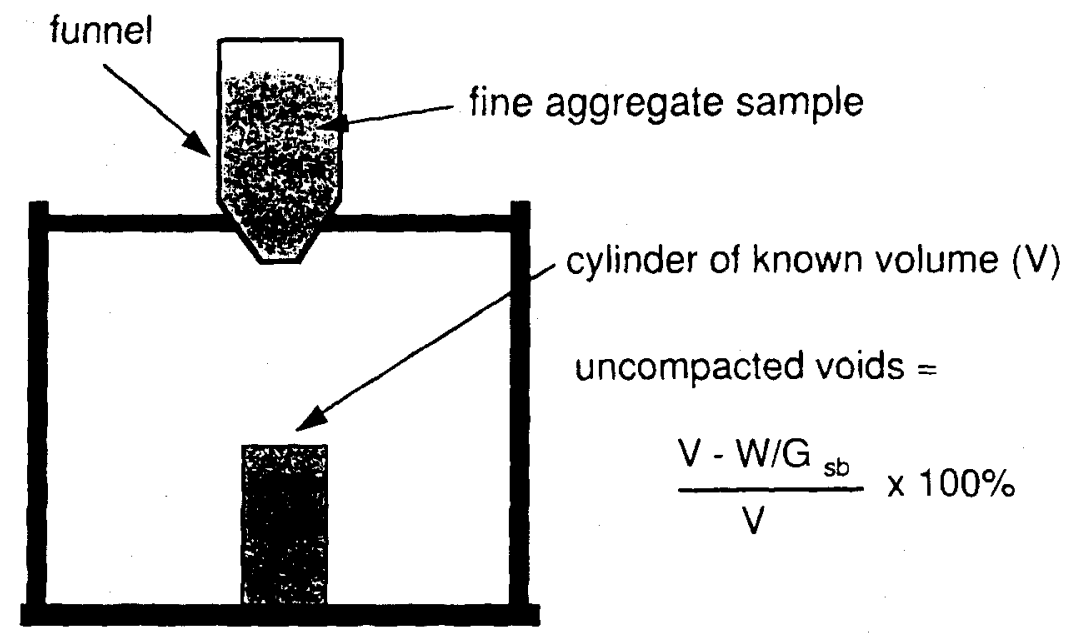

Reference: Superpave Mix Design Method for Asphalt Concrete, MS -2, Asphalt Institute, Lexington, Kentucky.

Table 3.2 fine aggregate angularity test result

\begin{tabular}{|l|c|}
\hline \multicolumn{1}{|c|}{ Description } & Data \\
\hline Volume of Cylindrical measure & $99.7 \mathrm{ml}$ \\
\hline Tare weight of cylindrical measure & $187.4 \mathrm{~g}$ \\
\hline Weight of sample + Cylindrical measure & $329.7 \mathrm{~g}$ \\
\hline Weight of sample & $142.3 \mathrm{~g}$ \\
\hline Bulk Specific gravity of fine aggregate & 2.843 \\
\hline Uncompacted voids & 49.8 \\
\hline
\end{tabular}

\subsubsection{Flat and Elongated Particles}

This characteristic is the percentage by mass of coarse aggregates that have maximum to minimum dimension ratio greater than five. Flat and elongated particles are undesirable because they have a tendency to break during construction and under traffic. The maximum limit for surface course should be $20 \%$ as per OPSS \# LS-608

The proportional caliper device as shown in Figure 3.1 measures the dimensional ratio of a representative sample of aggregate particles. 
Figure 3.2 Flat \& Elongation testing Caliper

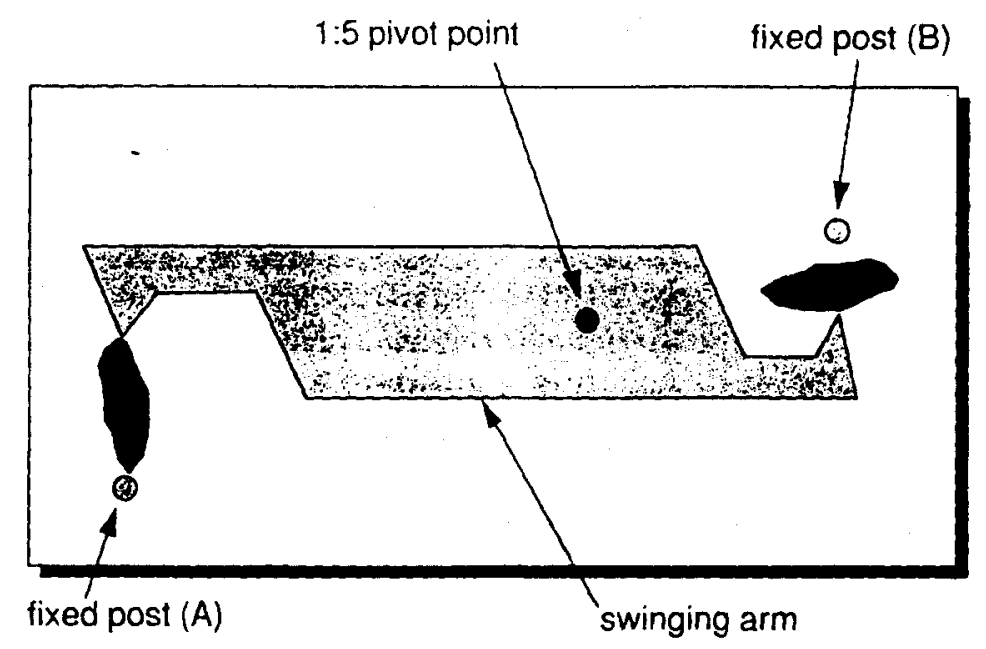

Reference: Superpave Mix Design Method for Asphalt Concrete, MS-2, Asphalt Institute, Lexington, Kentucky.

Table No.3.3 Flat \& Elongation of aggregates

\begin{tabular}{|c|c|c|c|c|c|}
\hline Fraction & $\begin{array}{c}\text { Mass of } \\
\text { original } \\
\text { Fraction }\end{array}$ & $\begin{array}{c}\text { Percent of } \\
\text { original } \\
\text { Fraction }\end{array}$ & $\begin{array}{c}\text { Flat \& } \\
\text { Elongated } \\
\text { Particles } \\
\text { Mass }\end{array}$ & $\begin{array}{c}\text { Flat \& } \\
\text { Cuss of } \\
\text { Elongated } \\
\%\end{array}$ & $\begin{array}{c}\text { Cubal } \\
\mathrm{mm}\end{array}$ \\
\hline $\begin{array}{c}26.5-13.2 \\
13.2-9.5 \mathrm{~mm}\end{array}$ & 500.9 & 28.5 & 9.1 & 491.8 & 1.82 \\
\hline \begin{tabular}{c}
$9.5-6.7 \mathrm{~mm}$ \\
\hline $6.7-4.75 \mathrm{~mm}$
\end{tabular} & 201.1 & 39.3 & 7.9 & 193.2 & 3.93 \\
\hline $\begin{array}{c}\text { Flat \& } \\
\text { Elongation } \\
\text { percentage } \\
\text { in Average }\end{array}$ & 75.8 & 19.3 & 4.1 & 71.7 & 5.41 \\
\hline
\end{tabular}




\subsubsection{Clay Content (Sand Equivalent)}

It is the percentage of clay material contained in the aggregate fraction that is finer than a $4.75 \mathrm{~mm}$ sieve. The sand equivalent value is computed as the ratio of the sand to clay height readings, expressed as a percentage. According to AASHTO T176 minimum should be $50 \%$. In figure 3.3 shows details about sand and clay reading.

Figure 3.3 Sand Equivalent beaker

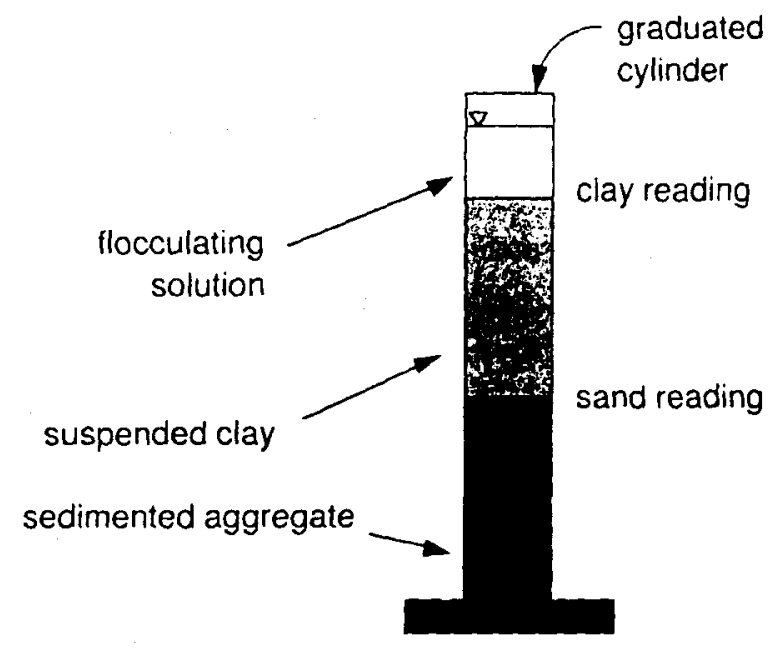

Reference: Superpave Mix Design Method for Asphalt Concrete, MS-2, Asphalt Institute, Lexington, Kentucky.

Table 3.4 Sand Equivalent Results

\begin{tabular}{|c|c|c|}
\hline \multirow{2}{*}{ Parameter } & \multicolumn{2}{|c|}{ Mechanical Shaker } \\
\cline { 2 - 3 } & Sample No. 1 & Sample No.2 \\
\hline Sand Reading & 5.4 & 4.1 \\
\hline Clay Reading & 7.6 & 6.1 \\
\hline Sand Equivalent & $71 \%$ & $73 \%$ \\
\hline
\end{tabular}




\subsubsection{Specific Gravity and Absorption (Coarse Aggregate)}

It measures the relative density (apparent, bulk and saturated, surface dry) and absorption of a sample of coarse aggregates. Aggregates are porous, not solid particles, water is absorbed by the particle in the pore spaces, which may be relatively shallow or may extend well into the aggregate particle. The specific Gravity and percent absorption for coarse aggregate comes out to be 2.859 and 0.652 respectively.

Table 3.5 Specific Gravity and Absorption of coarse aggregate

\begin{tabular}{|c|c|c|c|}
\hline & Sample Number & 1 & 2 \\
\hline \multicolumn{2}{|c|}{ Weight of oven dry specimen in Air \& Tare } & 3404.6 & 3223.6 \\
\hline \multicolumn{2}{|r|}{ Tare Weight } & 673 & 522.7 \\
\hline A & Weight of oven Dry specimen in Air & 2731.6 & 2700.9 \\
\hline $\mathrm{B}$ & $\begin{array}{l}\text { Weight of Saturated surface dry } \\
\text { specimen in Air }\end{array}$ & 2749.5 & 2718.4 \\
\hline $\mathrm{C}$ & Weight of saturated specimen in Water & 1795.5 & 1772.3 \\
\hline \multicolumn{4}{|c|}{ Bulk Specific Gravity (Dry Basis) } \\
\hline & $\begin{array}{c}\text { Bulk Specific Gravity } \\
=\mathrm{A} /(\mathrm{B}-\mathrm{C})\end{array}$ & 2.863 & 2.855 \\
\hline \multicolumn{4}{|c|}{ Absorption } \\
\hline & $\begin{array}{l}\text { Absorption \% }= \\
\text { (B-A) X 100/A }\end{array}$ & 0.655 & 0.648 \\
\hline & Average Bulk Specific Gravity & \multicolumn{2}{|c|}{2.859} \\
\hline & Average Absorption & \multicolumn{2}{|c|}{0.652} \\
\hline
\end{tabular}




\subsubsection{Specific Gravity and Absorption (Fine Aggregate)}

Table 3.6 Specific Gravity and Absorption fine Aggregate

\begin{tabular}{|c|c|c|c|}
\hline \multicolumn{2}{|c|}{ Sample Number } & 1 & 2 \\
\hline \multicolumn{2}{|c|}{ Weight of oven dry specimen in Air \& Tare } & 1192.1 & 1175.9 \\
\hline \multicolumn{2}{|c|}{ Tare Weight } & 690.1 & 673.2 \\
\hline A & Weight of oven Dry specimen in Air & 502 & 502.7 \\
\hline $\mathrm{B}$ & Weight of Pycnometer filled with water & 645.3 & 641 \\
\hline $\mathrm{C}$ & $\begin{array}{l}\text { Weight of Pycnometer, specimen \& } \\
\text { Water }\end{array}$ & 974.1 & 969.9 \\
\hline $\mathrm{D}$ & $\begin{array}{l}\text { Weight of Specimen if over than } 500 \\
\text { gms }\end{array}$ & 505.7 & 505.5 \\
\hline & Pycnometer Number & $\mathrm{B}$ & $\mathrm{C}$ \\
\hline \multicolumn{4}{|c|}{ Bulk Specific Gravity } \\
\hline \multicolumn{2}{|c|}{$\begin{array}{l}\text { Bulk Specific Gravity } \\
=\mathrm{A} /(\mathrm{B}+\mathrm{D}-\mathrm{C})\end{array}$} & 2.838 & 2.847 \\
\hline \multicolumn{4}{|c|}{ Absorption } \\
\hline \multicolumn{2}{|c|}{$\begin{array}{l}\text { Absorption \% } \% \\
(D-A) \times 100 / A\end{array}$} & 0.737 & 0.557 \\
\hline \multicolumn{2}{|c|}{ Average Absorption } & \multicolumn{2}{|c|}{0.647} \\
\hline \multicolumn{2}{|c|}{ Average Specific Gravity } & \multicolumn{2}{|c|}{2.843} \\
\hline
\end{tabular}

\subsubsection{Toughness}

Source properties are those, which are to be used to qualify local source of aggregate while these properties are very important and these are identified in Superpave, It is the present loss of material from an aggregate blend during the Los Angeles Abrasion test or through Micro Deval test. It estimates the resistance of coarse aggregate to abrasion and mechanical degradation during handling, construction and in service. Subjecting the coarse aggregate, usually larger than $2.36 \mathrm{~mm}$, to impact and grinding by steel spheres perform it. Maximum loss ranges from 35 to 45 percent as per LS-618 
Table 3.7 Micro-Deval of Course Aggregate

\begin{tabular}{|c|l|c|}
\hline \multirow{2}{*}{ PARAMETER } & Sample No.1 & Sample No.2 \\
\cline { 2 - 3 } & $\begin{array}{l}\text { WEIGHT } \\
(\mathrm{gm})\end{array}$ & $\begin{array}{c}\text { WEIGHT } \\
\text { (gm) }\end{array}$ \\
\hline Weight of Test Sample & 1502.5 & 1705.3 \\
\hline Weight of SS Balls & 5000.1 & 4999.2 \\
\hline $\begin{array}{c}\text { Weight of Sample (after } \\
\text { test) }\end{array}$ & 1381.3 & 1572 \\
\hline Loss(gm) & 121.2 & 133.0 \\
\hline$\%$ Loss & 8.1 & 7.8 \\
\hline
\end{tabular}

Table 3.8 Micro-Deval of Fine Aggregate

\begin{tabular}{|c|c|c|}
\hline \multirow{2}{*}{ PARAMETER } & Sample No.1 & Sample No.2 \\
\cline { 2 - 3 } & $\begin{array}{c}\text { WEIGHT } \\
\text { (gm) }\end{array}$ & $\begin{array}{c}\text { WEIGHT } \\
\text { (gm) }\end{array}$ \\
\hline Weight of Test Sample & 504.2 & 500.7 \\
\hline $\begin{array}{c}\text { Weight of SS Balls } \\
\begin{array}{c}\text { Weight of Sample (after } \\
\text { test) }\end{array}\end{array}$ & 1252.7 & 252.3 \\
\hline Loss(gm) & 469.5 & 458 \\
\hline$\%$ Loss & 34.7 & 42.7 \\
\hline
\end{tabular}

\subsection{Gradation}

Each material should qualify for required gradation for the mix design. In this study three samples were tested for gradation from each size of aggregate. The averages of three gradations were considered in blending. 


\subsubsection{Gradation of Coarse Aggregate}

Once the satisfactory aggregate materials, which meet the physical criteria for, mix design, and then it has to do the gradations to achieve the target limits which will comply with Ontario Provincial Standard Specification for Stone Mastic Asphalt. Table 3.9 shows the three different samples gradations and in figure 3.5 shows the graphical presentation of coarse aggregate.

Table 3.9 Gradation of Course Aggregate

\begin{tabular}{|c|c|c|c|}
\hline \multirow{2}{*}{$\begin{array}{c}\text { SIEVE SIZES } \\
(\mathbf{m m})\end{array}$} & \multicolumn{3}{|c|}{ MATERIALS PERCENT PASSING } \\
\cline { 2 - 4 } & $\begin{array}{c}\text { GRADATION } \\
\text { NO.1 }\end{array}$ & $\begin{array}{c}\text { GRADATION } \\
\text { NO.2 }\end{array}$ & $\begin{array}{c}\text { GRADATION } \\
\text { NO.3 }\end{array}$ \\
\hline 16.0 & 100.00 & 100.00 & 100.00 \\
\hline 13.2 & 99.65 & 99.00 & 99.78 \\
\hline 9.5 & 71.07 & 69.23 & 70.32 \\
\hline 6.7 & 31.85 & 30.21 & 31.97 \\
\hline 4.75 & 12.51 & 13.90 & 13.53 \\
\hline 2.36 & 5.79 & 6.35 & 6.74 \\
\hline 1.18 & 4.50 & 5.01 & 6.62 \\
\hline 0.600 & 3.71 & 2.85 & 4.43 \\
\hline 0.300 & 2.98 & 2.39 & 3.21 \\
\hline 0.150 & 2.32 & 1.84 & 2.1 \\
\hline 0.075 & 1.52 & 0.21 & 0.75 \\
\hline & & & \\
\hline
\end{tabular}


Figure 3.4 Graph for gradation of coarse aggregate

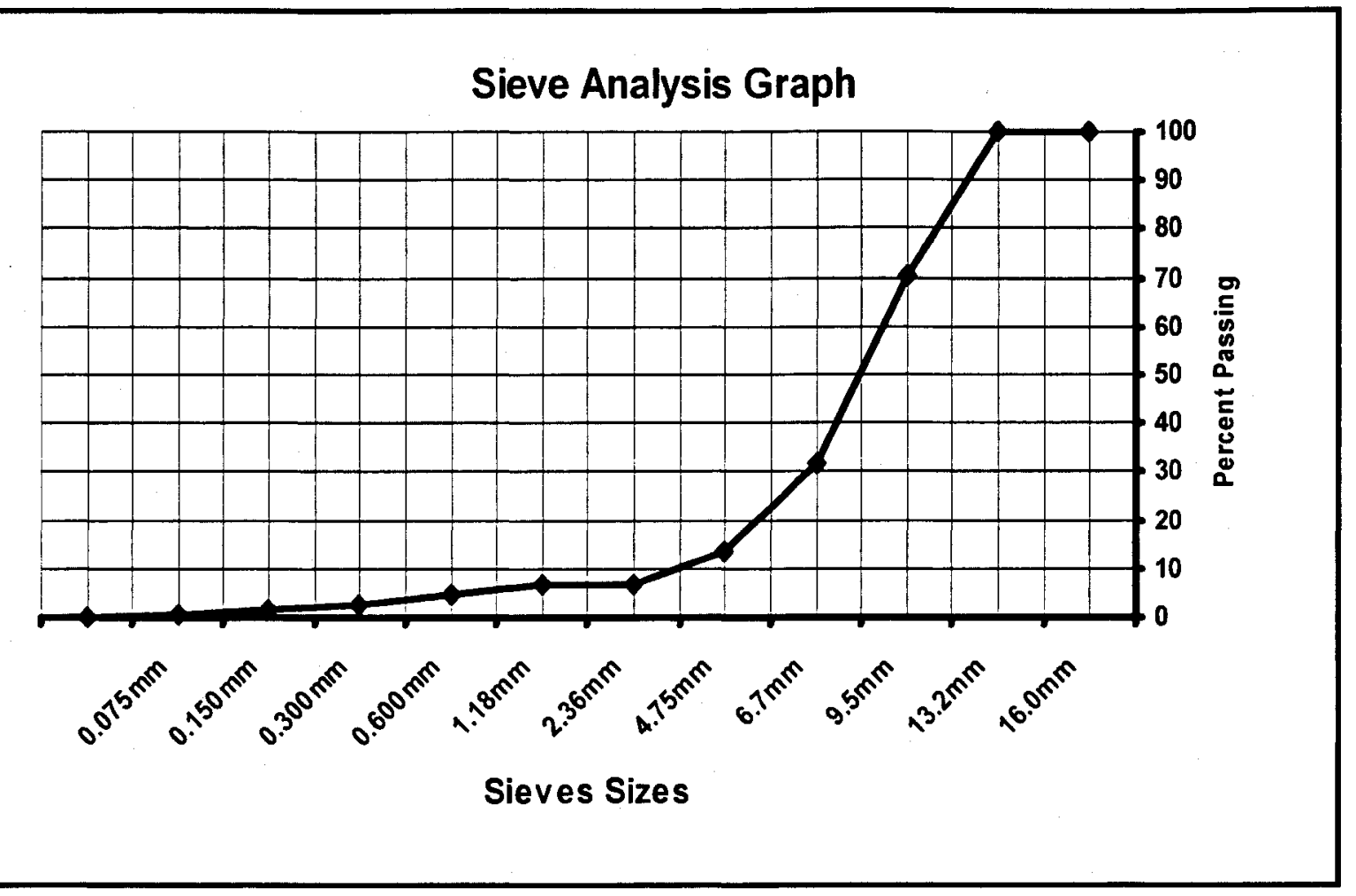

\subsubsection{Fine Aggregate Gradation}

Washed Screening from MRT quarry for the fine aggregates has been used, Table 3.10 shows the gradation of three different samples and figure 3.6. shows the graphical presentation of fine aggregates

Table 3.10 Gradation for fine aggregate

\begin{tabular}{|c|c|c|c|}
\hline \multirow{2}{*}{$\begin{array}{c}\text { SIEVE SIZES } \\
(\mathbf{m m})\end{array}$} & \multicolumn{3}{|c|}{ MATERIALS PERCENT PASSING } \\
\cline { 2 - 4 } & $\begin{array}{c}\text { GRADATION } \\
\text { NO.1 }\end{array}$ & $\begin{array}{c}\text { GRADATION } \\
\text { NO.2 }\end{array}$ & $\begin{array}{c}\text { GRADATION } \\
\text { NO.3 }\end{array}$ \\
\hline 6.7 & 100.00 & 100.00 & 100.00 \\
\hline 4.75 & 95.21 & 97.26 & 96.12 \\
\hline 2.36 & 67.58 & 68.99 & 65.82 \\
\hline 1.18 & 46.44 & 45.85 & 48.55 \\
\hline 0.600 & 33.77 & 35.17 & 35.85 \\
\hline 0.300 & 22.78 & 24.33 & 24.82 \\
\hline 0.150 & 14.84 & 15.86 & 12.82 \\
\hline 0.075 & 5.94 & 5.56 & 4.48 \\
\hline
\end{tabular}


Figure 3.5 Graph showing gradation of fine aggregate

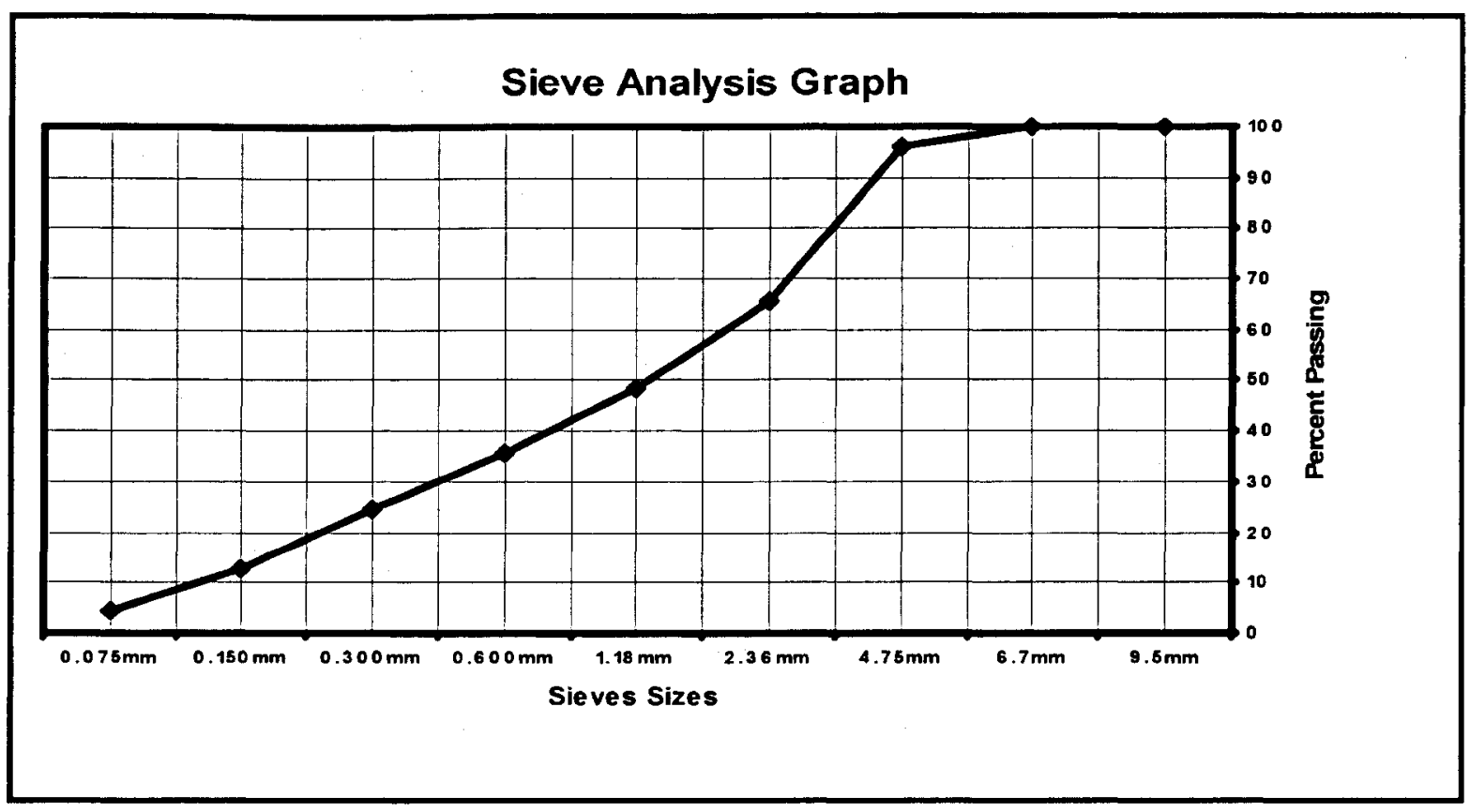

\subsubsection{Dust}

To achieve the filler requirement of Stone Mastic asphalt and to adjust the blending requirements to use the dust which is a waste material available at any asphalt plant in those plant, which has the dust collector system to prevent the environmental effects on weather and atmosphere. Table 3.11 shows the three different gradations of the dust and in figure 3.2 is graphical presentation of dust.

Table 3.11 Gradation for dust

\begin{tabular}{|c|c|c|c|}
\hline $\begin{array}{c}\text { SIEVE SIZES } \\
(\mathrm{mm})\end{array}$ & \multicolumn{3}{|c|}{ MATERIALS PERCENT PASSING } \\
\cline { 2 - 4 } & $\begin{array}{c}\text { GRADATION } \\
\text { NO.1 }\end{array}$ & $\begin{array}{c}\text { GRADATION } \\
\text { NO.2 }\end{array}$ & $\begin{array}{c}\text { GRADATION } \\
\text { NO.3 }\end{array}$ \\
\hline 2.36 & 100 & 100 & 100 \\
\hline 1.18 & 99.58 & 99.24 & 99.00 \\
\hline 0.600 & 99.20 & 98.10 & 98.6 \\
\hline 0.300 & 94.24 & 94.20 & 93.99 \\
\hline 0.150 & 83.50 & 84.10 & 83.00 \\
\hline 0.075 & 82.32 & 83.32 & 81.20 \\
\hline
\end{tabular}


Figure 3.6 Graph of gradation for dust

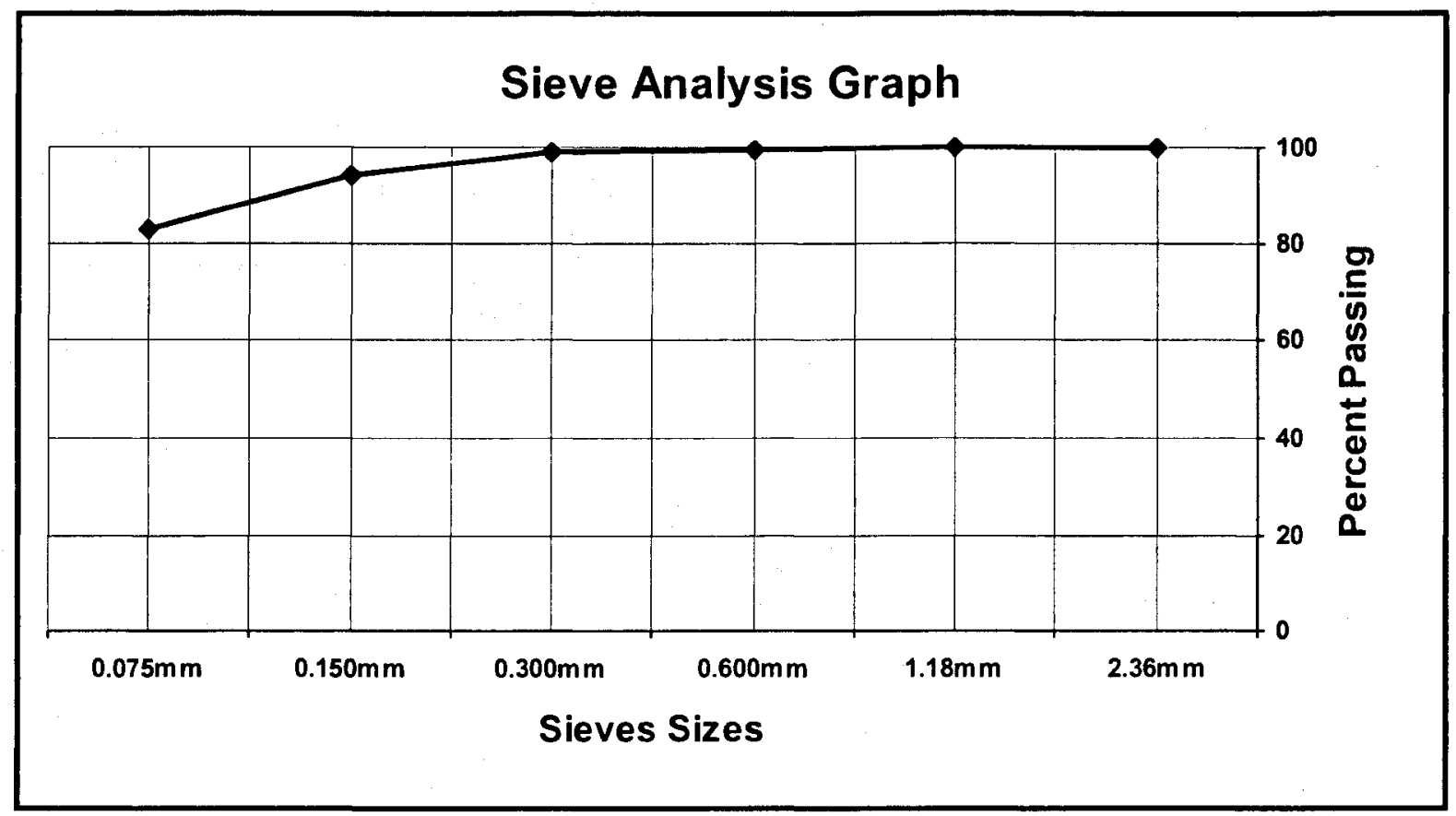

\subsubsection{Cement Kiln Dust (CKD)}

Cement Kiln dust collected from St. Lawrence Cement factory and is used as filler to replace the dust, the gradation is given in table 3.12

Table 3.12 Gradation of CKD

\begin{tabular}{|c|c|c|c|}
\hline \multirow{2}{*}{$\begin{array}{c}\text { SIEVE SIZES } \\
(\mathbf{m m})\end{array}$} & \multicolumn{3}{|c|}{ MATERIALS PERCENT PASSING } \\
\cline { 2 - 4 } & $\begin{array}{c}\text { GRADATION } \\
\text { NO.1 }\end{array}$ & $\begin{array}{c}\text { GRADATION } \\
\text { NO.2 }\end{array}$ & $\begin{array}{c}\text { GRADATION } \\
\text { NO.3 }\end{array}$ \\
\hline 2.36 & 100 & 100 & 100 \\
\hline 1.18 & 100 & 100 & 100 \\
\hline 0.600 & 99.76 & 99.20 & 99.99 \\
\hline 0.300 & 99.46 & 98.90 & 99.20 \\
\hline 0.150 & 99.24 & 98.00 & 98.10 \\
\hline 0.075 & 86.30 & 86.62 & 87.30 \\
\hline
\end{tabular}




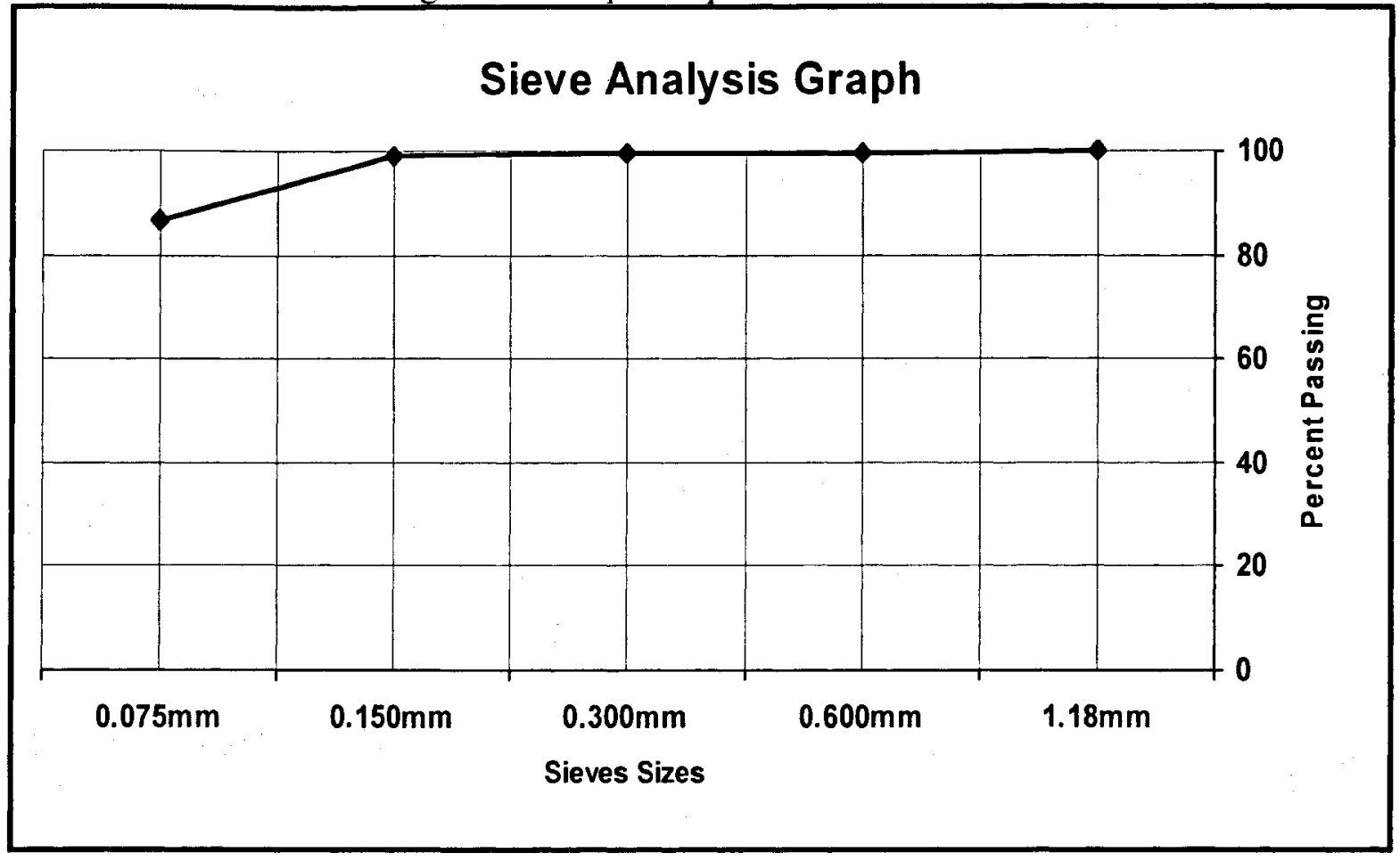

\subsection{Shingles}

In the Stone Mastic Asphalt, overcoming the drain down percentage is a common challenge, different researchers and asphalt concrete producers used fibers to meet the requirement of drain down, as we know that binder content is so high due to coarse aggregates.

In the experimental design tear off shingles were used as a source of fibers and compare the volumetric properties with control mix design.

The tear off shingles has been collected from waste yard near Brampton Ontario, those shingles contain average $30 \%$ binder content and the gradations are given in table 3.13 Figure 3.5 is the graphical presentation of shingle's gradation. 
Table 3.13 Gradation of Extracted Shingles

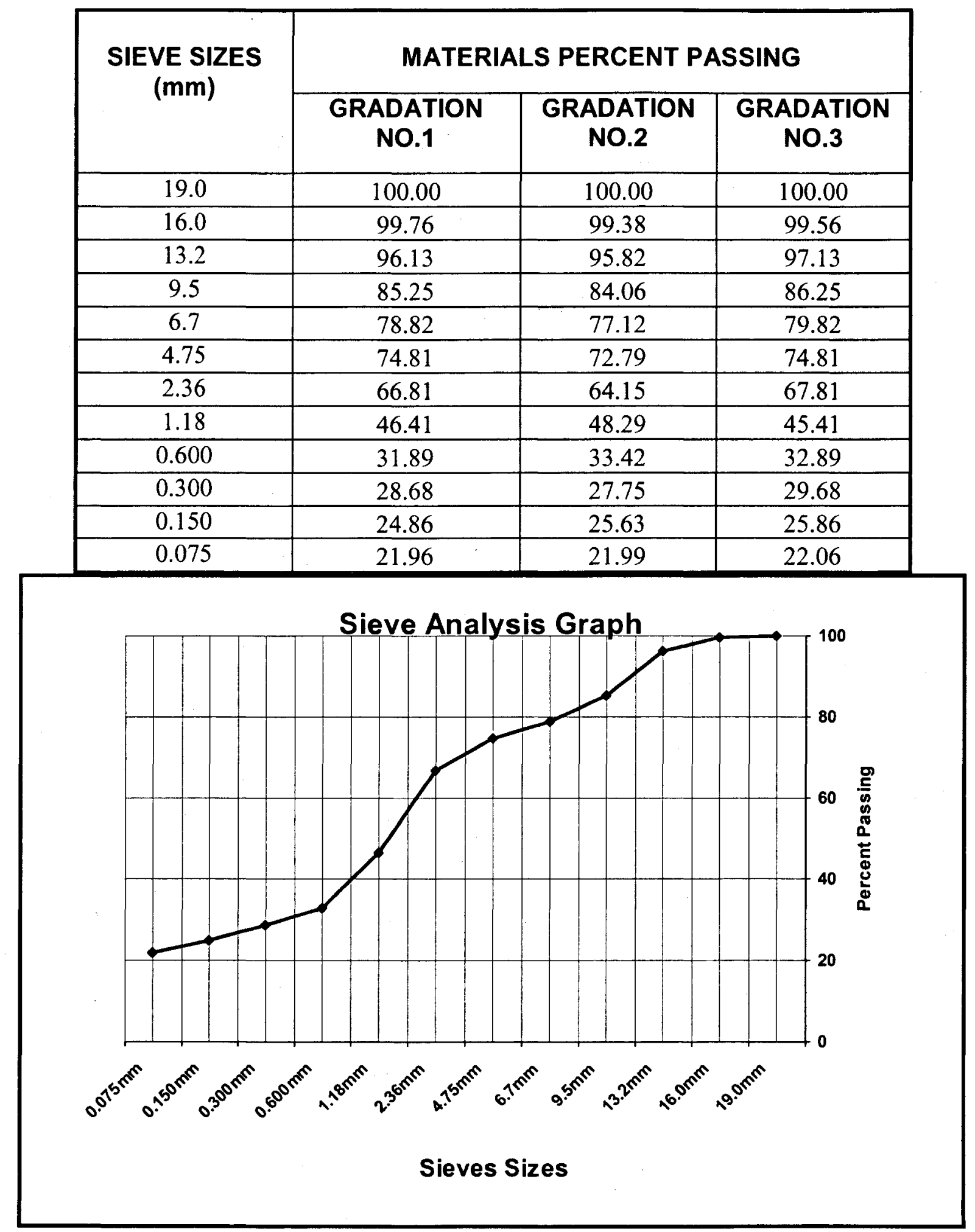

Figure 3.8 Graphical presentation of Extracted shingle's gradation 


\subsection{Fibers}

Fibers for stone mastic asphalt mixture may be either cellulose or mineral fiber and shall comply with requirements specified in Table 3.14.Cellulose fibers were used in this project. The fibers meet the requirements of OPSS No.313S45M May 2002

Table 3:14 Requirements of Fiber as OPSS \#313S45M May 2002

\begin{tabular}{|c|c|}
\hline \multicolumn{2}{|c|}{ Physical Properties } \\
\hline Fiber Length max., in. (mm) & $0.25(6.0)$ \\
\hline Ash Content (\%) & $13.0-23.0$ \\
\hline $\mathrm{PH}$ & $6.5-8.5$ \\
\hline Oil Absorption $\mathrm{x}$ fiber weight (mass) & $4.0-6.0$ \\
\hline Moisture Content max., $\%$ by weight (mass) & 5.0 \\
\hline \multicolumn{2}{|c|}{ Sieve Analysis } \\
\hline Sieve Size & $\%$ Passing by Weight (Mass) \\
\hline No. $100(150 \mathrm{um})$ & $60.0-80.0$ \\
\hline \multicolumn{2}{|c|}{ Mesh Screen Analysis } \\
\hline Sieve Size & \% Passing by Weight (Mass) \\
\hline No. $20(850 \mathrm{um})$ & $75.0-95.0$ \\
\hline No. $40(425 \mathrm{um})$ & $55.0-75.0$ \\
\hline No. 140 (106 um) & $20.0-40.0$ \\
\hline
\end{tabular}

\subsection{Binder}

In this experimental program (PG) Performance Grade 58-28 was selected since it is the type commonly used in GTA (Greater Toronto Area), the binder is supplied by McAsphalt Industries Ltd. 


\subsection{Design Parameters}

Mixtures were designed to meet the requirements of Ontario Provincial Standard Specification OPSS \# 313S45M May 2002, which are described below:

\subsubsection{Voids in Coarse Aggregate}

The integrity of the aggregate skeleton is assured by establishing that the Void in Coarse aggregate (VCA) of the SMA mixture is equal to or less than the VCA of the coarse aggregate fraction as determined by the dry rodded unit weight test. When designing SMA mixtures, it is suggested that at least three trial gradations be initially evaluated.

The percent air voids, voids in mineral aggregate and voids in coarse aggregate of the selected mix design compared with the requirements for air voids, voids in mineral aggregate and voids in coarse aggregate in the dry rodded condition.

With some aggregates, particularly soft ones, it may be difficult to meet the VMA requirements no matter how the aggregates are blended. The inability to meet the VMA requirements may be the result of excessive aggregate breakdown that is an indication the aggregate may be unsuitable for use in stone mastic asphalt mixtures. Thus every effort should be made to meet the VMA requirements.

The dry rodded density of coarse aggregate used in this study is $1689 \mathrm{~kg} / \mathrm{m}^{3}$

\subsubsection{Blending of Aggregate}

In asphalt mix design when all requirements of materials complied with specification, then it is required to prepare a blend with different ratios of selected materials to meet the target gradation of the specified mix. In our study it complies with the requirements for Stone Mastic Asphalt with Ontario Provincial Standard Specification Special Provision No. 313S45M.

In first trial blend the selected coarse aggregate was $68 \%$, fine aggregate was $22 \%$, shingles was $5 \%$ and dust was $5 \%$. As first trial blend did not achieve the required gradation, different blends have to be tried to achieve the target-grading curve, the selected blending of aggregates is given in Table 3.15 and graphical presentation in Figure 3.7. 
Table 3.15 Aggregate Blending for trial blend A with 5\% shingles

\begin{tabular}{|c|c|c|c|c|c|c|c|c|c|c|c|}
\hline \multicolumn{12}{|c|}{ AGGREGATE BLENDING SHEET } \\
\hline Material & \multicolumn{2}{|c|}{$\frac{\text { MRT COARSE }}{70 \%}$} & \multicolumn{2}{|c|}{$\begin{array}{c}\text { MRT Washed } \\
\text { Screening } \\
20 \%\end{array}$} & \multicolumn{2}{|c|}{$\frac{\text { SHINGLES }}{5 \%}$} & \multicolumn{2}{|c|}{$\frac{\text { Dust }}{5 \%}$} & \multirow[b]{2}{*}{$\begin{array}{l}\text { Blend } \\
\% \text { age }\end{array}$} & \multicolumn{2}{|c|}{$\begin{array}{c}\text { Target as per } \\
\text { OPSS\#.313S45M } \\
\text { May } 2002\end{array}$} \\
\hline $\begin{array}{c}\text { Sieves in } \\
\mathrm{mm}\end{array}$ & $\begin{array}{c}\% \\
\text { Passing }\end{array}$ & $\begin{array}{c}\% \\
\text { Batch }\end{array}$ & $\begin{array}{c}\% \\
\text { Passing }\end{array}$ & $\begin{array}{c}\% \\
\text { Batch }\end{array}$ & $\begin{array}{c}\% \\
\text { Passing }\end{array}$ & $\begin{array}{c}\% \\
\text { Batch }\end{array}$ & $\begin{array}{c}\% \\
\text { Passing }\end{array}$ & $\begin{array}{c}\% \\
\text { Batch }\end{array}$ & & $\begin{array}{l}\text { Lower } \\
\text { Limit }\end{array}$ & $\begin{array}{l}\text { Upper } \\
\text { Limit }\end{array}$ \\
\hline 26.5 & 100.00 & 70.00 & 100.00 & 20.00 & 100.00 & 5.00 & 100.00 & 5.00 & 100.00 & 100 & 100 \\
\hline 19.0 & 100.00 & 70.00 & 100.00 & 20.00 & 100.00 & 5.00 & 100.00 & 5.00 & 100.00 & 100 & 100 \\
\hline 16.0 & 100.00 & 70.00 & 100.00 & 20.00 & 100.00 & 5.00 & 100.00 & 5.00 & 100.00 & 100 & 100 \\
\hline 13.2 & 99.60 & 69.72 & 100.00 & 20.00 & 96.13 & 4.81 & 100.00 & 5.00 & 99.53 & 90 & 100 \\
\hline 9.5 & 71.10 & 49.77 & 100.00 & 20.00 & 85.25 & 4.26 & 100.00 & 5.00 & 79.03 & 50 & 85 \\
\hline 6.7 & 31.80 & 22.26 & 100.00 & 20.00 & 78.82 & 3.94 & 100.00 & 5.00 & 51.20 & 35 & 62.5 \\
\hline 4.75 & 12.50 & 8.75 & 95.21 & 19.04 & 74.81 & 3.74 & 100.00 & 5.00 & 36.53 & 20 & 40 \\
\hline 2.36 & 5.80 & 4.06 & 67.60 & 13.52 & 66.81 & 3.34 & 100.00 & 5.00 & 25.92 & 16 & 28 \\
\hline 1.18 & 4.50 & 3.15 & 46.47 & 9.29 & 46.50 & 2.33 & 100.00 & 5.00 & 19.77 & 14 & 25 \\
\hline 0.600 & 3.70 & 2.59 & 33.81 & 6.76 & 32.89 & 1.64 & 100.00 & 5.00 & 16.00 & 12 & 20 \\
\hline 0.300 & 3.00 & 2.10 & 22.83 & 4.57 & 28.68 & 1.43 & 100.00 & 5.00 & 13.10 & 10 & 15 \\
\hline 0.150 & 2.30 & 1.61 & 14.89 & 3.0 & 24.68 & 1.2 & 100.00 & 5.0 & 10.82 & 9 & 12 \\
\hline 0.075 & 1.51 & 1.06 & 5.99 & 1.2 & 21.96 & 1.1 & 96.00 & 4.8 & 8.15 & 8 & 11 \\
\hline
\end{tabular}




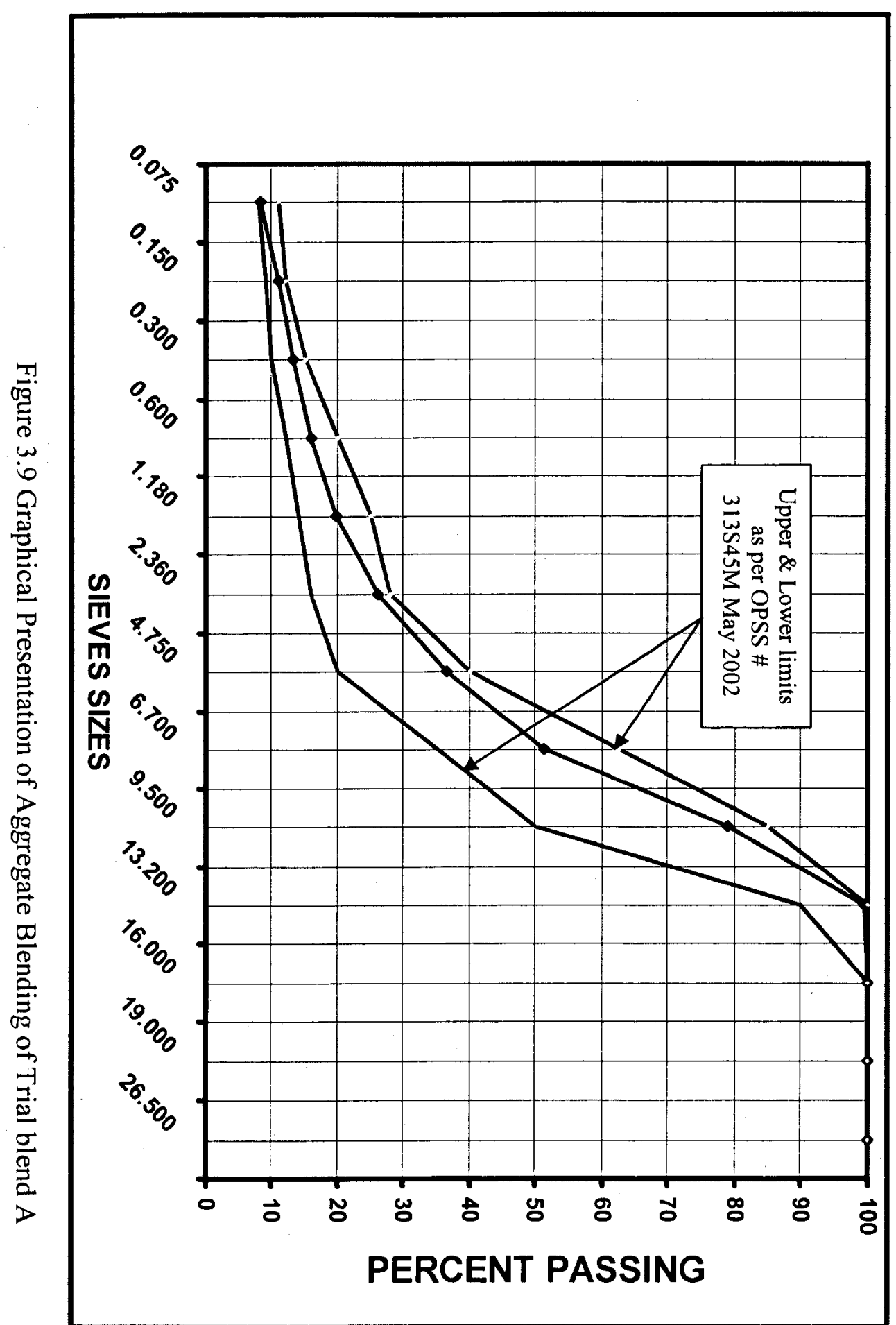




\subsubsection{Preparation of Asphalt Mix}

After blending of aggregates was finalized, three batches of aggregate with different blending ratios were kept in the oven for overnight to dry. On next day asphalt mix with initial percent of binder were prepared. Three batches of mix will be prepared by using mechanical mixer in the laboratory.

Each batch of mix was enough for one specimen of Superpave, two specimens were prepared and one mix was used for Theoretical Maximum Density. The asphalt mixes were placed in conditioned oven for short-term absorption (for two hours) to correlates with the mix prepared at asphalt plant and delivered to paving site.

The Superpave method of mix design was used in this study. Strategic Highway Research Program (SHRP) researchers had several goals in developing a laboratory compaction method, the important point was they want to realistically compact mixture test specimen to densities achieved under actual pavement climate and loading conditions. The compacting equipment was required to be capable of accommodating large size of aggregates and to measure the degree of compaction and height as well.

The basis for the Superpave Gyratory Compactor (SGC) was the Texas gyratory compactor that was modified to use the compaction principles of a French gyratory compactor. The modified Texas gyratory accomplished the goals of realistic specimen densification and it was reasonably portable. Its 6-inch sample diameter that will be $150 \mathrm{~mm}$ on SGC would be effectively reasonable for maximum size of aggregates.

The Superpave gyratory compactor has following parts, which show in figure 3.15 [23]

- Reaction frame, rotating base and motor

- Loading system, loading ram, and pressure gauge

- Height measuring and recording system

- Mold and Base plate Specimen Extruding device 
Figure 3.10 Gyratory Compacting Systems

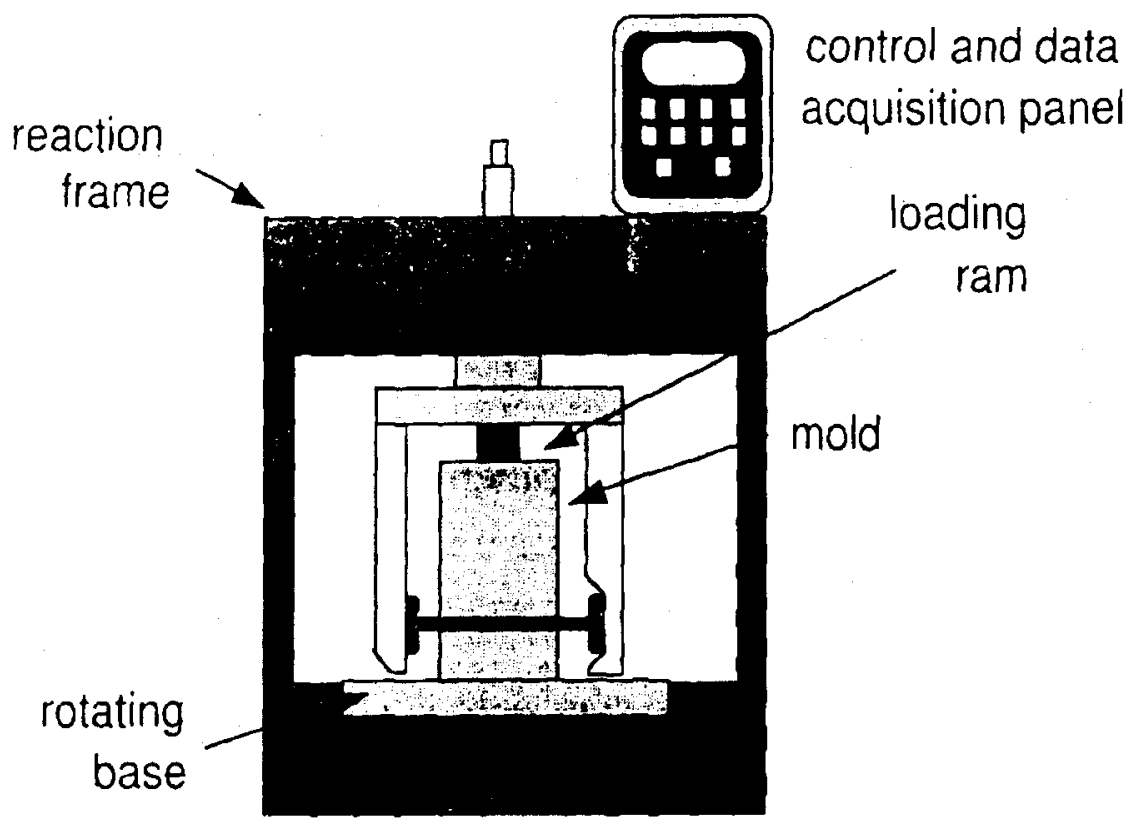

Reference: Superpave Mix Design Method for Asphalt Concrete, MS-2, Asphalt Institute, Lexington, Kentucky.

A loading mechanism presses against the reaction frame and applies a load to the loading ram to produce a 600 -kpa-compaction pressure on the specimen. A pressure gauge measures the ram loading to maintain constant pressure during the compaction. The SGC mold has an internal diameter of $150 \mathrm{~mm}$ and a base plate in the bottom of the mold provides confinement during compaction and the base rotates at a constant rate of 30 gyrations per minute during compaction, with the mold positioned at a compaction angle of 1.25 degrees as shown in Figure 3.12 [23] 
Figure 3.11 Loading Mechanisms in Gyratory Compactor

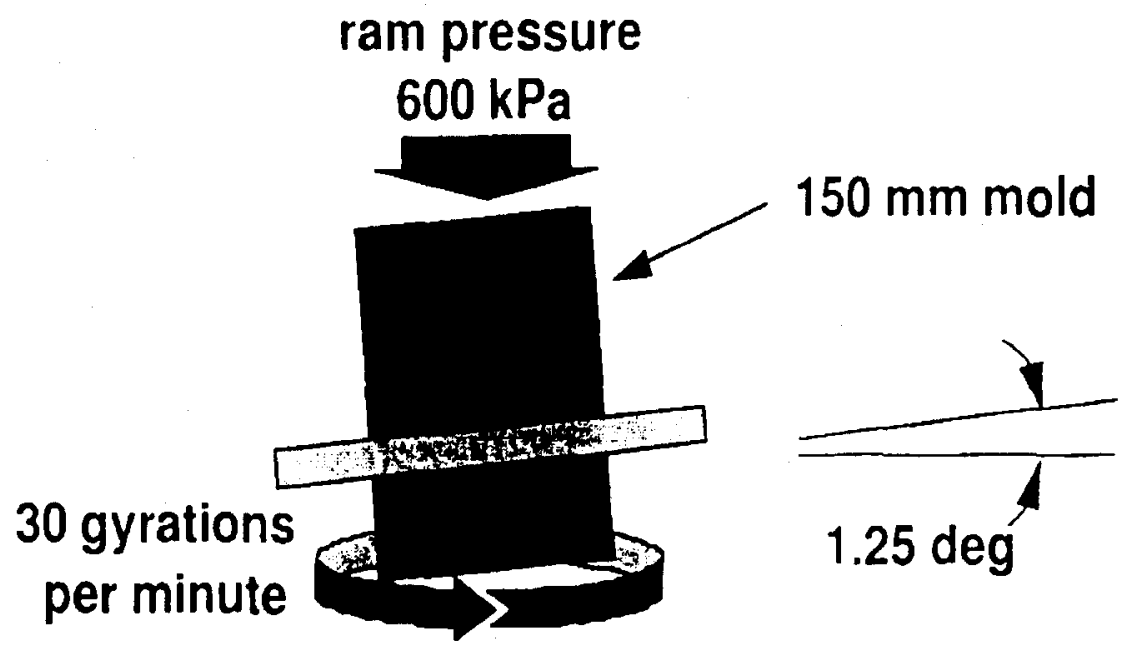

Reference: Superpave Mix Design Method for Asphalt Concrete, MS-2, Asphalt Institute, Lexington, Kentucky.

Next, a minimum of two specimens for each trial blend is compacted using the SGC. Two samples are also prepared for determination of the mixture's maximum theoretical specific gravity $\left(\mathrm{G}_{\mathrm{mm}}\right)$. An average weight of mix for one specimen was $5000 \mathrm{~g}$, which is usually sufficient for the compacted specimens. An aggregate weight of 2000 grams is usually sufficient for the specimens used to determine maximum theoretical specific gravity $\left(\mathrm{G}_{\mathrm{mm}}\right)$. AASHTO T-209 should be consulted to determine the minimum sample size required for various mixtures.

The number of gyrations used for compaction is determined based on the traffic level; it is explained in table No. 3.16 with reference to Superpave method of mix design guide MS-2

Table 3.16 Details about Gyration and traffic

\begin{tabular}{|l|c|c|c|}
\hline \multirow{2}{*}{$\begin{array}{c}\text { Design ESAL } \\
\text { (millions) }\end{array}$} & \multicolumn{3}{|c|}{ Compaction Parameters } \\
\cline { 2 - 4 } & $\mathbf{N}_{\text {(initial) }}$ & $\mathbf{N}_{\text {(design) }}$ & $\mathbf{N}_{\text {(maximum) }}$ \\
\hline Less than 0.3 & 6 & 50 & 75 \\
\hline From 0.3 to 3 & 7 & 75 & 115 \\
\hline From 3 to 30 & 8 & 100 & 160 \\
\hline Greater than 30 & 9 & 125 & 205 \\
\hline
\end{tabular}


In this project Stone Mastic Asphalt is chosen and as per their requirement, the number of gyrations for initial compaction, design compaction and maximum compaction are mentioned in OPSS \#313S45M May 2002

$\mathrm{N}_{\text {(initial) }}=8$ gyrations

$\mathrm{N}_{(\text {design) }}=100$ gyrations

$\mathrm{N}_{\text {(maximum) }}=160$ gyrations

\subsubsection{Calculation for $\% \mathbf{G}_{\mathrm{mm}}$}

Each specimen was compacted to the design number of gyrations, with specimen height data collected during the compaction process.

During compaction, the height of the specimen is continuously monitored. After compaction is complete, the specimen is extruded from the mold and allowed to cool. Next, the bulk specific gravity $\left(\mathrm{G}_{\mathrm{mb}}\right)$ of the specimen is determined using AASHTO T166. The $\mathrm{G}_{\mathrm{mm}}$ of each blend is determined using AASHTO T209. $\mathrm{G}_{\mathrm{mb}}$ is then divided by $\mathrm{G}_{\mathrm{mm}}$ to determine the $\% \mathrm{G}_{\mathrm{mm}} @ \mathrm{~N}_{\text {des. }}$. The $\% \mathrm{G}_{\mathrm{mm}}$ at any number of gyrations $(\mathrm{Nx})$ is then calculated by multiplying $\% \mathrm{G}_{\mathrm{mm}} @ \mathrm{~N}_{\text {des }}$ by the ratio of the heights at $\mathrm{N}_{\text {des }}$ and $\mathrm{Nx}$ Superpave gyratory compaction data is analyzed by computing the estimated bulk specific gravity, corrected bulk specific gravity, and corrected percentage of maximum theoretical specific gravity for each desired gyration. During compaction, the height is measured and recorded after each gyration. $\mathrm{G}_{\mathrm{mb}}$ of compacted specimen and $\mathrm{G}_{\mathrm{mm}}$ of loose mixture are measured. An estimate of $G_{m b}$ at any value of gyration is made by dividing the mass of the mixture by volume of the compaction mold.

\subsection{5 $\mathrm{N}_{(\max )}$ Verification}

Superpave specifies a maximum density of $98 \%$ at $\mathrm{N}_{(\max )}$. Specifying a maximum density at $\mathrm{N}$ prevents design of a mixture that will compact excessively under traffic, 
become plastic, and produce permanent deformation. Since $\mathrm{N}_{(\max )}$ represents a compactive effort that would he equivalent to traffic much greater than the design traffic, excessive compaction will not occur. After selecting the blend and selecting the design asphalt binder content (4.0\%) two additional specimens are compacted to 160 gyrations.

\subsubsection{Drain down percentage}

One of the problems that have been observed with SMA is draindown of the asphalt cement resulting in fat spots. The percentage of drain down in the mix resulting from dripping has to be checked. This is done through measuring the amount of asphalt cement that passes through a standard mesh. See Figure.No.3.6 for draindown basket assembly. The basket with the mix was placed into a preheated oven and maintained at $152^{\circ} \mathrm{C}$ for two hours. Pre-weighed papers were placed underneath the container to collect the asphalt cement drippings. The drippings were collected and weighed after one-hour period. The same procedure was repeated for another sample with the oven temperature at $165^{\circ} \mathrm{C}$. The weights were calculated and expressed as a percentage of the initial weight of the mix and the numbers were reported as percent draindown. The maximum percent of draindown should not exceed $0.3 \%$ as per requirement of OPSS \# 313S45M May 2002

Figure No.3.12 Draindown basket assembly
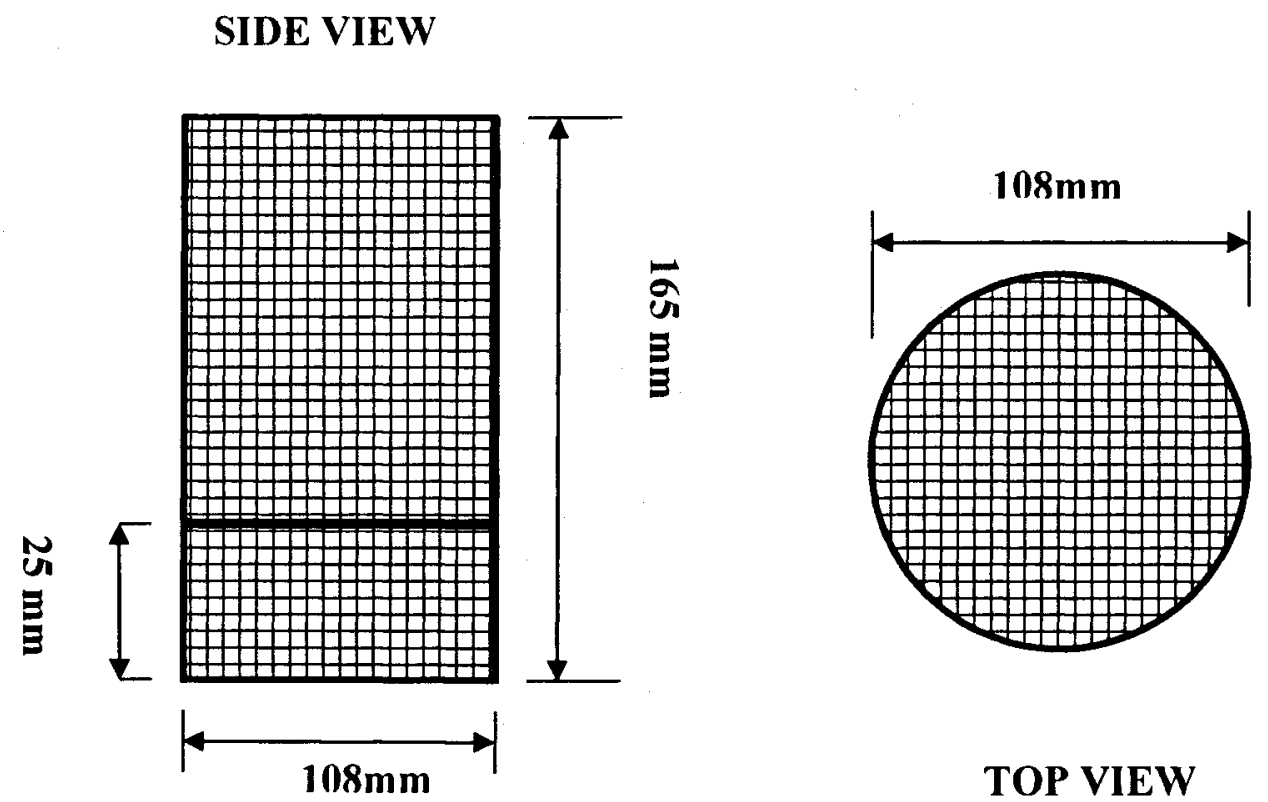

TOP VIEW 


\subsubsection{Moisture Sensitivity}

Moisture susceptibility was determined in accordance with AASHTO T 283. Six briquettes $(95 \mathrm{~mm})$ were prepared and compacted at $6 \%$ to $7 \%$ air voids, three of them will be tested for dry strength and three were vacuum saturated, freezing for 16-24 hours and than kept in water bath for $60^{\circ} \mathrm{C}$ for 24 hours and then tested as wet strength. The average tensile strength ratio should not be less than $70 \%$. For tensile strength ratio, many laboratories use the same load frame, which used to be used for Marshall Stability. The indirect tensile test uses the same specimen orientation but the breaking head has been modified to induce a more theoretically correct application of the load. 


\section{Chapter 4}

\section{Results and Analysis}

\subsection{Analysis of Results}

In this chapter every mix design will be discussed with respect to volumetric properties. Five different SMA Mixes has been designed and investigated. These are given in Table 4.1

Table 4.1 Mix design description

\begin{tabular}{|c|l|}
\hline $\begin{array}{c}\text { Mix } \\
\text { Number }\end{array}$ & \multicolumn{1}{c|}{ Description } \\
\hline $\mathbf{1}$ & $5 \%$ Shingles + Baghouse dust as mineral filler \\
\hline $\mathbf{1 B}$ & $5 \%$ Shingles + CKD as mineral filler \\
\hline $\mathbf{2}$ & $3 \%$ Shingles + Baghouse dust as mineral filler \\
\hline $\mathbf{3}$ & $0.6 \%$ Fibers + Baghouse dust as mineral filler \\
\hline $\mathbf{4}$ & $0.3 \%$ Fibers + Baghouse dust as mineral filler \\
\hline $\mathbf{5}$ & $10 \%$ Shingles + CKD as mineral filler \\
\hline
\end{tabular}

\subsubsection{Trials to reach optimum result}

It is assumed that all binder (asphalt cement) in the shingles is "available" to the mixture. Since the asphalt content of the shingles used in this study is $30 \%$, in this way $5 \%$ shingles will provide $1.5 \%$ asphalt to the mixture.

The first mixture was conducted at $5 \%$ shingles. To adjust the aggregate blending, three blends $\mathrm{A}, \mathrm{B}$ and $\mathrm{C}$ were conducted at different aggregate blending ratios and a total asphalt(binder) content of 5.5\% ( $4 \%$ version binder and $1.5 \%$ from shingles). These are shown in Table 4.2 
The blend of trial $\mathrm{C}$ was chosen since it provides the $4 \%$ air voids and adequate VMA. After that, the same aggregate blending was tried at three binder contents namely $5,5.5$ and $6 \%$ as detailed in section 4.11

Table 4.2 Results of different trials

\begin{tabular}{|c|c|c|c|}
\hline \multirow{2}{*}{ Parameter } & \multicolumn{3}{|c|}{ Results } \\
\cline { 2 - 4 } & $\begin{array}{c}\text { Blend } \\
\text { A }\end{array}$ & $\begin{array}{c}\text { Blend } \\
\text { B }\end{array}$ & $\begin{array}{c}\text { Blend } \\
\text { C }\end{array}$ \\
\hline $\begin{array}{c}\text { Binder Content (\%) } \\
\text { including from Shingles }\end{array}$ & 5.5 & 5.5 & 5.5 \\
\hline $\begin{array}{c}\text { Maximum Relative } \\
\text { Density }\end{array}$ & 2.599 & 2.622 & 2.618 \\
\hline $\begin{array}{c}\text { Bulk Relative Density } \\
\text { \% Gmm @ Nini }\end{array}$ & 2.524 & 2.534 & 2.513 \\
\hline $\begin{array}{c}\text { \% Gmm @ Ndes } \\
\text { Air Voids (\%) Ndes }\end{array}$ & 96.97 & 87.0 & 85.99 \\
\hline VMA (\%) & 16.83 & 96.64 & 95.99 \\
\hline $\begin{array}{c}\text { Voids filled with Asphalt } \\
\text { (VFA) (\%) }\end{array}$ & 86.05 & 86.85 & 86.81 \\
\hline
\end{tabular}


Table 4.3 Aggregate Blending for trial blend A which contain 5\% shingles

\begin{tabular}{|c|c|c|c|c|c|c|c|c|c|c|c|}
\hline \multicolumn{12}{|c|}{ AGGREGATE BLENDING SHEET } \\
\hline$\frac{\text { Material }}{\% \text { Used }}$ & \multicolumn{2}{|c|}{$\begin{array}{c}\text { MRT COARSE } \\
70 \%\end{array}$} & \multicolumn{2}{|c|}{$\begin{array}{c}\begin{array}{c}\text { MRT Washed } \\
\text { Screening }\end{array} \\
20 \% \\
\end{array}$} & \multicolumn{2}{|c|}{$\frac{\text { SHINGLES }}{5 \%}$} & \multicolumn{2}{|c|}{$\frac{\text { Dust }}{5 \%}$} & \multirow[b]{2}{*}{$\begin{array}{l}\text { Blend } \\
\text { \%age }\end{array}$} & \multicolumn{2}{|c|}{$\begin{array}{c}\text { Target as per } \\
\text { OPSS\#.313S45M } \\
\text { May } 2002\end{array}$} \\
\hline $\begin{array}{c}\text { Sieves in } \\
\mathrm{mm}\end{array}$ & $\begin{array}{c}\% \% \\
\text { Passing } \\
\end{array}$ & $\begin{array}{c}\% \\
\text { Batch }\end{array}$ & $\begin{array}{c}\% \\
\text { Passing }\end{array}$ & $\begin{array}{c}\% \\
\text { Batch }\end{array}$ & $\begin{array}{c}\% \\
\text { Passing }\end{array}$ & $\begin{array}{c}\% \\
\text { Batch }\end{array}$ & $\begin{array}{c}\% \\
\text { Passing }\end{array}$ & $\begin{array}{c}\% \\
\text { Batch }\end{array}$ & & $\begin{array}{l}\text { Lower } \\
\text { Limit }\end{array}$ & $\begin{array}{l}\text { Upper } \\
\text { Limit }\end{array}$ \\
\hline 26.5 & 100.00 & 70.00 & 100.00 & 20.00 & 100.00 & 5.00 & 100.00 & 5.00 & 100.00 & 100 & 100 \\
\hline 19.0 & 100.00 & 70.00 & 100.00 & 20.00 & 100.00 & 5.00 & 100.00 & 5.00 & 100.00 & 100 & 100 \\
\hline 16.0 & 100.00 & 70.00 & 100.00 & 20.00 & 100.00 & 5.00 & 100.00 & 5.00 & 100.00 & 100 & 100 \\
\hline 13.2 & 99.60 & 69.72 & 100.00 & 20.00 & 96.13 & 4.81 & 100.00 & 5.00 & 99.53 & 90 & 100 \\
\hline 9.5 & 71.10 & 49.77 & 100.00 & 20.00 & 85.25 & 4.26 & 100.00 & 5.00 & 79.03 & 50 & 85 \\
\hline 6.7 & 31.80 & 22.26 & 100.00 & 20.00 & 78.82 & 3.94 & 100.00 & 5.00 & 51.20 & 35 & 62.5 \\
\hline 4.75 & 12.50 & 8.75 & 95.21 & 19.04 & 74.81 & 3.74 & 100.00 & 5.00 & 36.53 & 20 & 40 \\
\hline 2.36 & 5.80 & 4.06 & 67.60 & 13.52 & 66.81 & 3.34 & 100.00 & 5.00 & 25.92 & 16 & 28 \\
\hline 1.18 & 4.50 & 3.15 & 46.47 & 9.29 & 46.50 & 2.33 & 100.00 & 5.00 & 19.77 & 14 & 25 \\
\hline 0.600 & 3.70 & 2.59 & 33.81 & 6.76 & 32.89 & 1.64 & 100.00 & 5.00 & 16.00 & 12 & 20 \\
\hline 0.300 & 3.00 & 2.10 & 22.83 & 4.57 & 28.68 & 1.43 & 100.00 & 5.00 & 13.10 & 10 & 15 \\
\hline 0.150 & 2.30 & 1.61 & 14.89 & 3.0 & 24.68 & 1.2 & 100.00 & 5.0 & 10.82 & 9 & 12 \\
\hline 0.075 & 1.51 & 1.06 & 5.99 & 1.2 & 21.96 & 1.1 & 96.00 & 4.8 & 8.15 & 8 & 11 \\
\hline
\end{tabular}




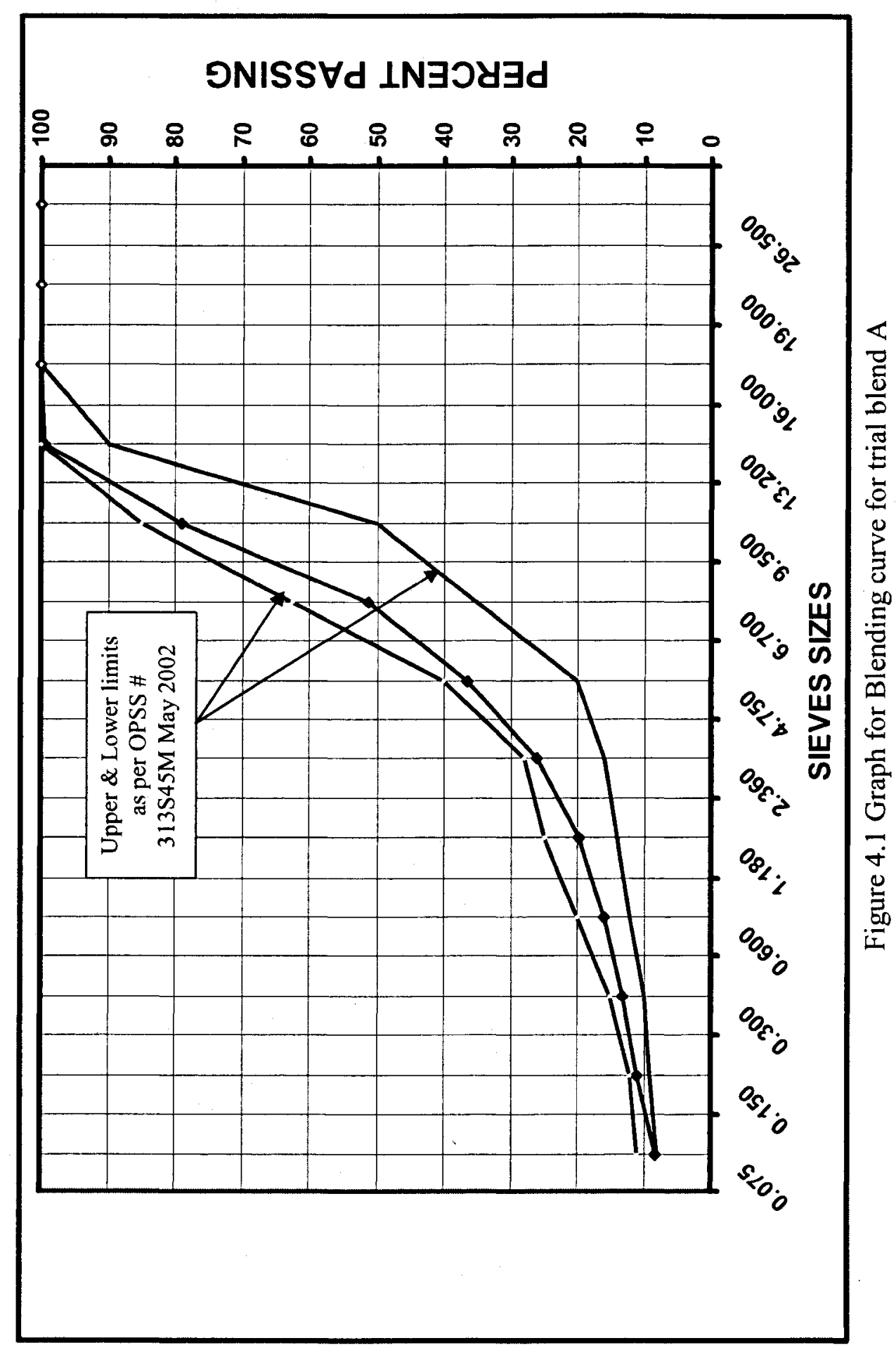


Table 4.4 Aggregate blending for trial Blend B containing 5\% shingles

\begin{tabular}{|c|c|c|c|c|c|c|c|c|c|c|c|}
\hline \multicolumn{12}{|c|}{ AGGREGATE BLENDING SHEET } \\
\hline$\frac{\text { Material }}{\% \text { Used }}$ & \multicolumn{2}{|c|}{$\frac{\text { MRT COARSE }}{75 \%}$} & \multicolumn{2}{|c|}{$\begin{array}{c}\text { MRT Washed } \\
\text { Screening }\end{array}$} & \multicolumn{2}{|c|}{$\frac{\text { SHINGLES }}{5 \%}$} & \multicolumn{2}{|c|}{$\frac{\text { Dust }}{5 \%}$} & \multirow[b]{2}{*}{$\begin{array}{l}\text { Blend } \\
\text { \%age }\end{array}$} & \multicolumn{2}{|c|}{$\begin{array}{c}\text { Target as per } \\
\text { OPSS\#.313S45M May } \\
2002\end{array}$} \\
\hline $\begin{array}{c}\text { Sieves in } \\
\mathrm{mm}\end{array}$ & $\begin{array}{c}\% \\
\text { Passing } \\
\end{array}$ & $\begin{array}{c}\% \\
\text { Batch }\end{array}$ & $\begin{array}{c}\% \\
\text { Passing }\end{array}$ & $\begin{array}{c}\% \\
\text { Batch }\end{array}$ & $\begin{array}{c}\% \\
\text { Passing }\end{array}$ & $\begin{array}{c}\% \\
\text { Batch }\end{array}$ & $\begin{array}{c}\% \\
\text { Passing }\end{array}$ & $\begin{array}{c}\% \\
\text { Batch }\end{array}$ & & $\begin{array}{c}\text { Lower } \\
\text { Limit }\end{array}$ & $\begin{array}{l}\text { Upper } \\
\text { Limit }\end{array}$ \\
\hline 26.5 & 100.00 & 75.00 & 100.00 & 15.00 & 100.00 & 5.00 & 100.00 & 5.00 & 100.00 & 100 & 100 \\
\hline 19.0 & 100.00 & 75.00 & 100.00 & 15.00 & 100.00 & 5.00 & 100.00 & 5.00 & 100.00 & 100 & 100 \\
\hline 16.0 & 100.00 & 75.00 & 100.00 & 15.00 & 100.00 & 5.00 & 100.00 & 5.00 & 100.00 & 100 & 100 \\
\hline 13.2 & 99.60 & 74.70 & 100.00 & 15.00 & 96.13 & 4.81 & 100.00 & 5.00 & 99.51 & 90 & 100 \\
\hline 9.5 & 71.10 & 53.33 & 100.00 & 15.00 & 85.25 & 4.26 & 100.00 & 5.00 & 77.59 & 50 & 85 \\
\hline 6.7 & 31.80 & 23.85 & 100.00 & 15.00 & 78.82 & 3.94 & 100.00 & 5.00 & 47.79 & 35 & 62.5 \\
\hline 4.75 & 12.50 & 9.38 & 95.21 & 14.28 & 74.81 & 3.74 & 100.00 & 5.00 & 32.40 & 20 & 40 \\
\hline 2.36 & 5.80 & 4.35 & 67.60 & 10.14 & 66.81 & 3.34 & 100.00 & 5.00 & 22.83 & 16 & 28 \\
\hline 1.18 & 4.50 & 3.38 & 46.47 & 6.97 & 46.50 & 2.33 & 100.00 & 5.00 & 17.67 & 14 & 25 \\
\hline 0.600 & 3.70 & 2.78 & 33.81 & 5.07 & 32.89 & 1.64 & 100.00 & 5.00 & 14.49 & 12 & 20 \\
\hline 0.300 & 3.00 & 2.25 & 22.83 & 3.42 & 28.68 & 1.43 & 100.00 & 5.00 & 12.11 & 10 & 15 \\
\hline 0.150 & 2.30 & 1.73 & 14.89 & 2.2 & 24.68 & 1.2 & 100.00 & 5.0 & 10.19 & 9 & 12 \\
\hline 0.075 & 1.51 & 1.13 & 5.99 & 0.9 & 21.96 & 1.1 & 96.00 & 4.8 & 7.93 & 8 & 11 \\
\hline
\end{tabular}




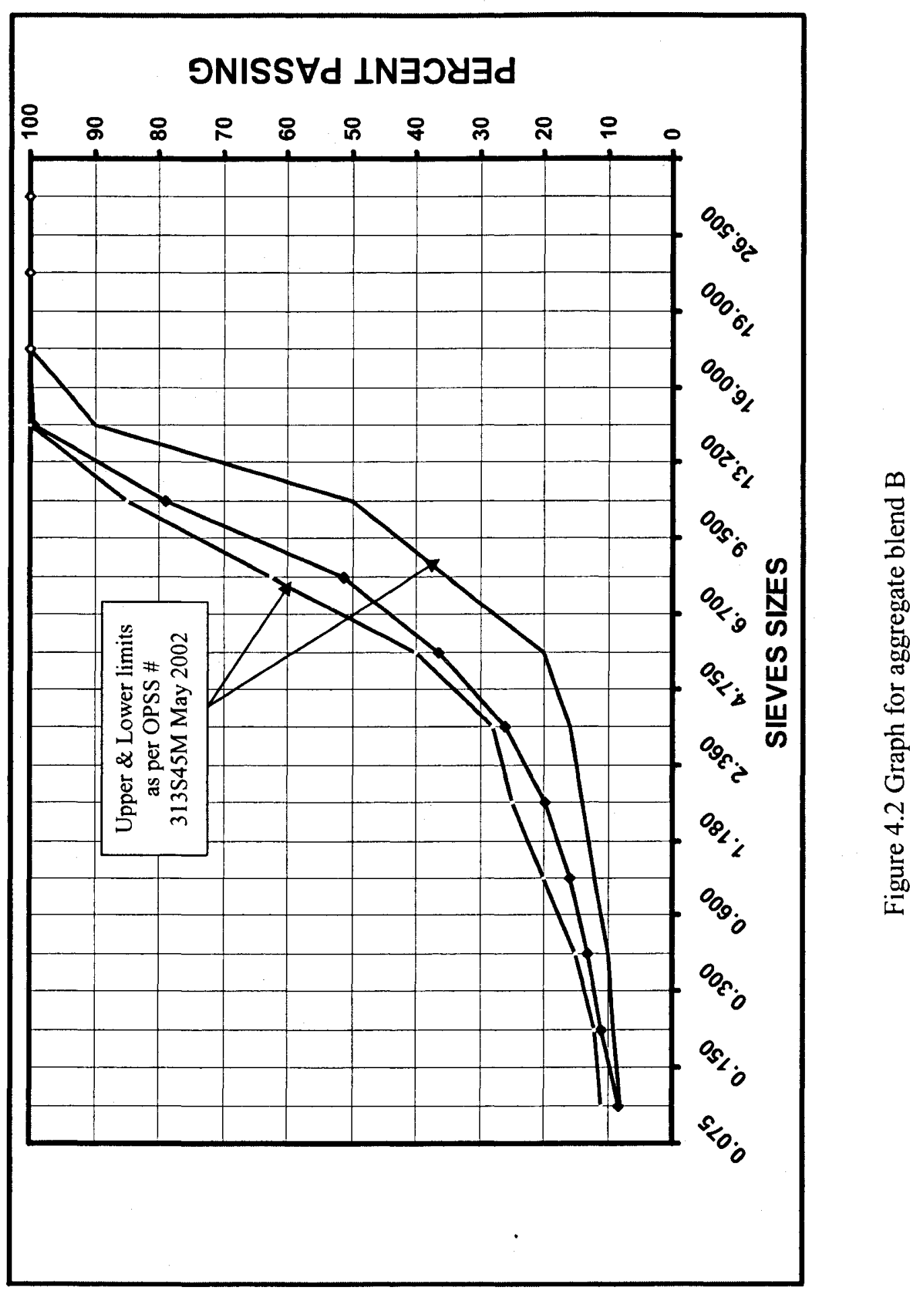


Table 4.5 Aggregate blending for Trial Blend $\mathrm{C}$ which contains 5\% shingles where proper air voids achieved

\begin{tabular}{|c|c|c|c|c|c|c|c|c|c|c|c|}
\hline \multicolumn{12}{|c|}{ AGGREGATE BLENDING SHEET } \\
\hline Material & \multicolumn{2}{|c|}{ MRT COARSE } & \multicolumn{2}{|c|}{$\begin{array}{l}\text { MRT Washed } \\
\text { Screening }\end{array}$} & \multicolumn{2}{|c|}{ SHINGLES } & \multicolumn{2}{|c|}{ Dust } & \multirow[b]{3}{*}{$\begin{array}{l}\text { Blend } \\
\text { \%age }\end{array}$} & \multirow{2}{*}{\multicolumn{2}{|c|}{$\begin{array}{c}\text { Target as per } \\
\text { OPSS\#.313S45M Maj } \\
2002\end{array}$}} \\
\hline$\%$ Used & 78 & & 10 & & 5 & & 7 & & & & \\
\hline $\begin{array}{c}\text { Sieves in } \\
\mathrm{mm}\end{array}$ & $\begin{array}{c}\% \\
\text { Passing } \\
\end{array}$ & \begin{tabular}{|c|}
$\%$ \\
Batch \\
\end{tabular} & $\begin{array}{c}\% \\
\text { Passing } \\
\end{array}$ & $\begin{array}{c}\% \\
\text { Batch }\end{array}$ & $\begin{array}{c}\% \\
\text { Passing } \\
\end{array}$ & $\begin{array}{c}\% \\
\text { Batch } \\
\end{array}$ & $\begin{array}{c}\% \\
\text { Passing } \\
\end{array}$ & $\begin{array}{c}\% \\
\text { Batch } \\
\end{array}$ & & $\begin{array}{l}\text { Lower } \\
\text { Limit }\end{array}$ & $\begin{array}{l}\text { Upper } \\
\text { Limit }\end{array}$ \\
\hline 26.5 & 100.00 & 78.00 & 100.00 & 10.00 & 100.00 & 5.00 & 100.00 & 7.00 & 100.00 & 100 & 100 \\
\hline 19.0 & 100.00 & 78.00 & 100.00 & 10.00 & 100.00 & 5.00 & 100.00 & 7.00 & 100.00 & 100 & 100 \\
\hline 16.0 & 100.00 & 78.00 & 100.00 & 10.00 & 100.00 & 5.00 & 100.00 & 7.00 & 100.00 & 100 & 100 \\
\hline 13.2 & 99.60 & 77.69 & 100.00 & 10.00 & 96.13 & 4.81 & 100.00 & 7.00 & 99.49 & 90 & 100 \\
\hline 9.5 & 71.10 & 55.46 & 100.00 & 10.00 & 85.25 & 4.26 & 100.00 & 7.00 & 76.72 & 50 & 85 \\
\hline 6.7 & 31.80 & 24.80 & 100.00 & 10.00 & 78.82 & 3.94 & 100.00 & 7.00 & 45.75 & 35 & 62.5 \\
\hline 4.75 & 12.50 & 9.75 & 95.21 & 9.52 & 74.81 & 3.74 & 100.00 & 7.00 & 30.01 & 20 & 40 \\
\hline 2.36 & 5.80 & 4.52 & 67.60 & 6.76 & 66.81 & 3.34 & 100.00 & 7.00 & 21.62 & 16 & 28 \\
\hline 1.18 & 4.50 & 3.51 & 46.47 & 4.65 & 46.50 & 2.33 & 100.00 & 7.00 & 17.48 & 14 & 25 \\
\hline 0.600 & 3.70 & 2.89 & 33.81 & 3.38 & 32.89 & 1.64 & 100.00 & 7.00 & 14.91 & 12 & 20 \\
\hline 0.300 & 3.00 & 2.34 & 22.83 & 2.28 & 28.68 & 1.43 & 100.00 & 7.00 & 13.06 & 10 & 15 \\
\hline 0.150 & 2.30 & 1.79 & 14.89 & 1.5 & 24.68 & 1.2 & 100.00 & 7.0 & 11.52 & 9 & 12 \\
\hline 0.075 & 1.51 & 1.18 & 5.99 & 0.6 & 21.96 & 1.1 & 96.00 & 6.7 & 9.59 & 8 & 11 \\
\hline
\end{tabular}




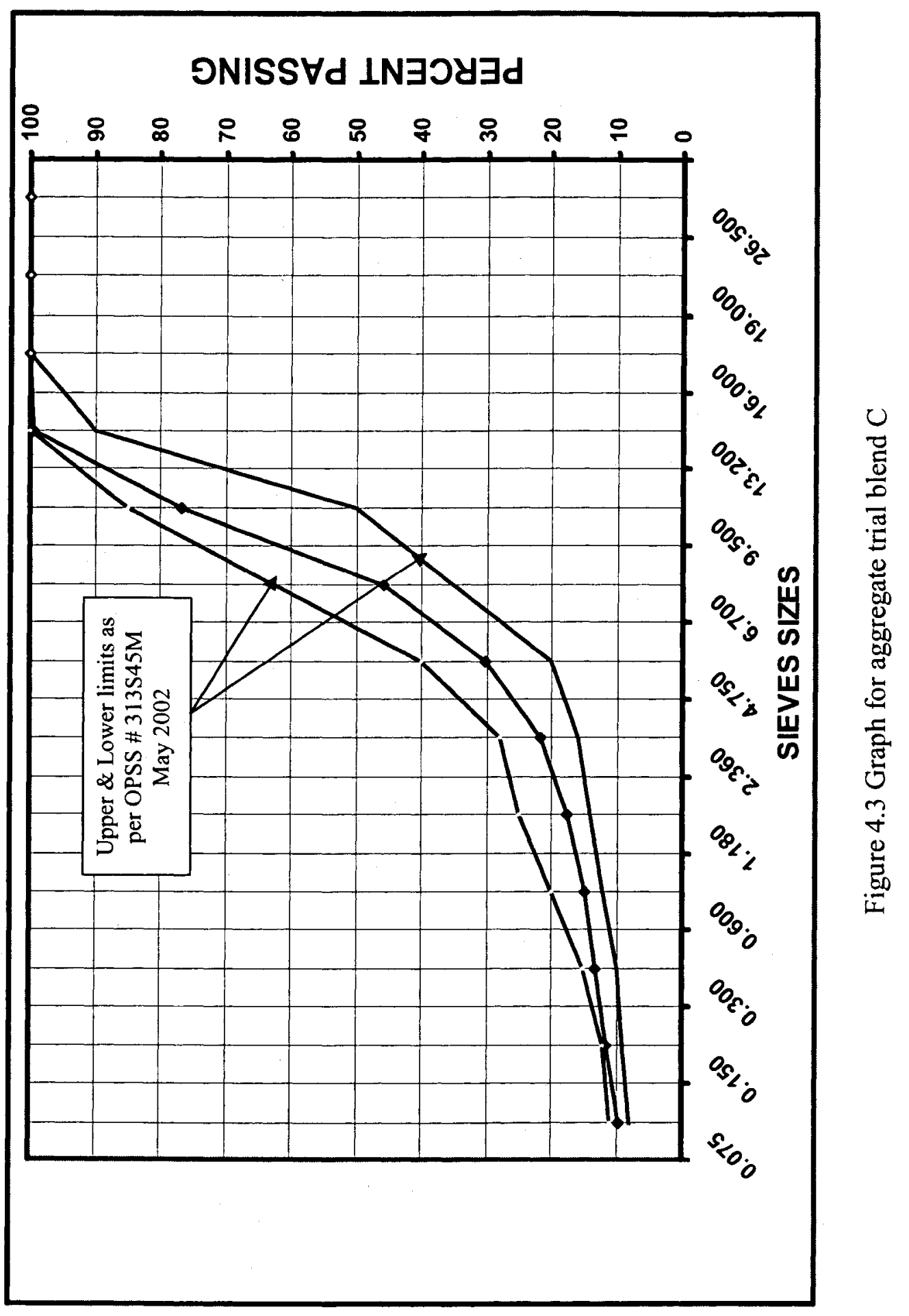




\subsubsection{SMA Mix design No.1}

This mix design contains $5 \%$ shingles, $78 \%$ coarse aggregate, $10 \%$ fine aggregate and $7 \%$ dust. Three trials with lower (5\%), optimum (5.5\%) and maximum (6\%) binder content prepared. The detailed results are given in appendix $\mathrm{A}$ to appendix $\mathrm{C}$; some of properties are given in Table 4.6

Table 4.6 Results of SMA mix design No.1

\begin{tabular}{||l|c|c|c||}
\hline \multicolumn{1}{|c|}{ Parameter } & \multicolumn{3}{c|}{ Results } \\
\hline $\begin{array}{l}\text { Binder Content (\%) including } \\
\text { from Shingles }\end{array}$ & 5.0 & 5.5 & 6.0 \\
\hline Maximum Relative Density & 2.641 & 2.618 & 2.600 \\
\hline Bulk Relative Density & 2.483 & 2.513 & 2.513 \\
\hline \% Gmm @ Nini & 83.0 & 86.0 & 88.4 \\
\hline \% Gmm @ Ndes & 94.0 & 96.0 & 97.8 \\
\hline Air Voids (\%) Ndes & 6.0 & 4.0 & 2.2 \\
\hline VMA (\%) & 17.25 & 17.2 & 17.64 \\
\hline VFA (\%) & 65.2 & 76.7 & 87.5 \\
\hline $\begin{array}{l}\text { Tensile Strength Ratio (\%) at } \\
\text { optimum binder content }\end{array}$ & \multicolumn{3}{|c|}{90.94} \\
\hline $\begin{array}{l}\text { Draindown(\%) at Optimum } \\
\text { Binder content }\end{array}$ & $\begin{array}{l}0.10(<0.3 \% \text { specified by } \\
\text { OPSS \#313S45M May 2002) }\end{array}$ \\
\hline
\end{tabular}


Table 4.7 Aggregate blending for SMA mix design No.1 which contains 5\% shingles

\begin{tabular}{|c|c|c|c|c|c|c|c|c|c|c|c|}
\hline \multicolumn{12}{|c|}{ AGGREGATE BLENDING SHEET } \\
\hline Material & \multicolumn{2}{|c|}{ MRT COARSE } & \multicolumn{2}{|c|}{$\begin{array}{l}\text { MRT Washed } \\
\text { Screening }\end{array}$} & \multicolumn{2}{|c|}{$\frac{\text { SHINGLES }}{5 \%}$} & \multicolumn{2}{|c|}{$\frac{\text { Dust }}{7 \%}$} & \multirow[b]{2}{*}{$\begin{array}{l}\text { Blend } \\
\text { \%age }\end{array}$} & \multicolumn{2}{|c|}{$\begin{array}{c}\text { Target as per } \\
\text { OPSS\#.313S45M May } \\
2002 \\
\end{array}$} \\
\hline $\begin{array}{c}\text { Sieves in } \\
\mathrm{mm}\end{array}$ & $\begin{array}{c}\% \\
\text { Passing } \\
\end{array}$ & $\begin{array}{c}\% \\
\text { Batch } \\
\end{array}$ & $\begin{array}{c}\% \\
\text { Passing } \\
\end{array}$ & $\begin{array}{c}\% \\
\text { Batch } \\
\end{array}$ & $\begin{array}{c}\% \\
\text { Passing } \\
\end{array}$ & $\begin{array}{c}\% \\
\text { Batch } \\
\end{array}$ & $\begin{array}{c}\% \\
\text { Passing } \\
\end{array}$ & $\begin{array}{c}\% \\
\text { Batch } \\
\end{array}$ & & $\begin{array}{l}\text { Lower } \\
\text { Limit }\end{array}$ & $\begin{array}{l}\text { Upper } \\
\text { Limit }\end{array}$ \\
\hline 26.5 & 100.00 & 78.00 & 100.00 & 10.00 & 100.00 & 5.00 & 100.00 & 7.00 & 100.00 & 100 & 100 \\
\hline 19.0 & 100.00 & 78.00 & 100.00 & 10.00 & 100.00 & 5.00 & 100.00 & 7.00 & 100.00 & 100 & 100 \\
\hline 16.0 & 100.00 & 78.00 & 100.00 & 10.00 & 100.00 & 5.00 & 100.00 & 7.00 & 100.00 & 100 & 100 \\
\hline 13.2 & 99.60 & 77.69 & 100.00 & 10.00 & 96.13 & 4.81 & 100.00 & 7.00 & 99.49 & 90 & 100 \\
\hline 9.5 & 71.10 & 55.46 & 100.00 & 10.00 & 85.25 & 4.26 & 100.00 & 7.00 & 76.72 & 50 & 85 \\
\hline 6.7 & 31.80 & 24.80 & 100.00 & 10.00 & 78.82 & 3.94 & 100.00 & 7.00 & 45.75 & 35 & 62.5 \\
\hline 4.75 & 12.50 & 9.75 & 95.21 & 9.52 & 74.81 & 3.74 & 100.00 & 7.00 & 30.01 & 20 & 40 \\
\hline 2.36 & 5.80 & 4.52 & 67.60 & 6.76 & 66.81 & 3.34 & 100.00 & 7.00 & 21.62 & 16 & 28 \\
\hline 1.18 & 4.50 & 3.51 & 46.47 & 4.65 & 46.50 & 2.33 & 100.00 & 7.00 & 17.48 & 14 & 25 \\
\hline 0.600 & 3.70 & 2.89 & 33.81 & 3.38 & 32.89 & 1.64 & 100.00 & 7.00 & 14.91 & 12 & 20 \\
\hline 0.300 & 3.00 & 2.34 & 22.83 & 2.28 & 28.68 & 1.43 & 100.00 & 7.00 & 13.06 & 10 & 15 \\
\hline 0.150 & 2.30 & 1.79 & 14.89 & 1.5 & 24.68 & 1.2 & 100.00 & 7.0 & 11.52 & 9 & 12 \\
\hline 0.075 & 1.51 & 1.18 & 5.99 & 0.6 & 21.96 & 1.1 & 96.00 & 6.7 & 9.59 & 8 & 11 \\
\hline
\end{tabular}


Figure 4.5Property Curves for SMA mix design No.1

Binder Content VS Bulk Relative Density

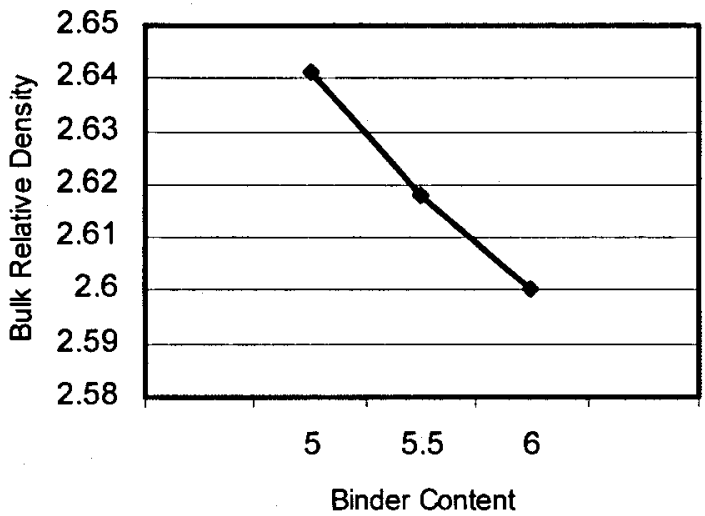

Binder Content VS Air Voids

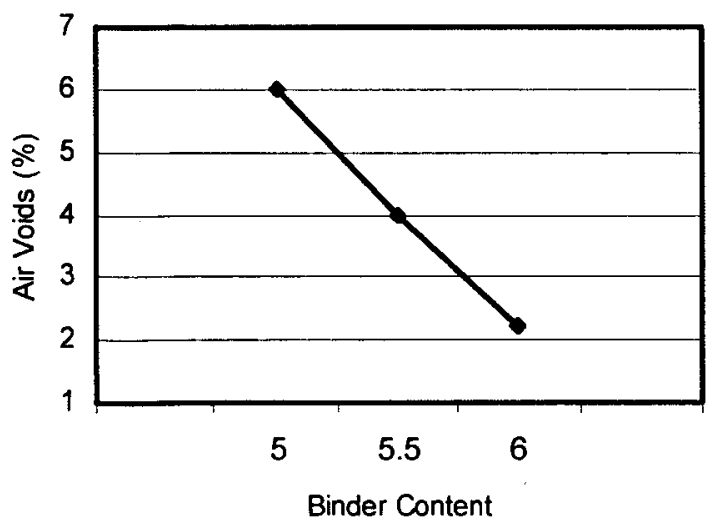

Binder Content VS \% Gmm @ N(design)

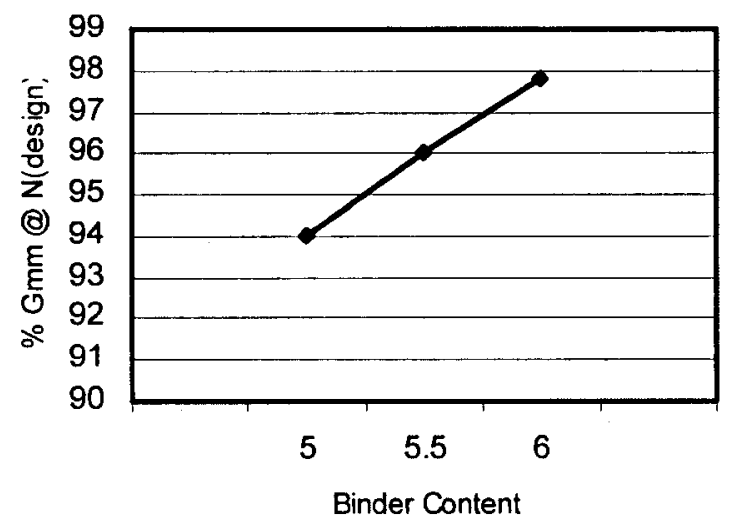

Binder Content VS VFA

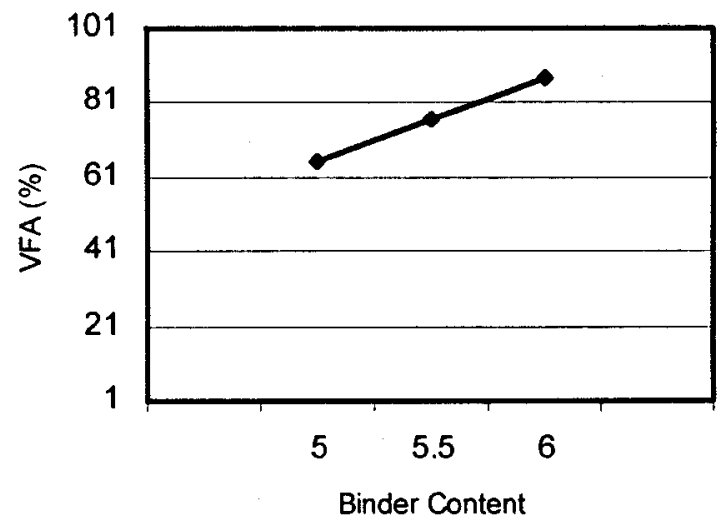




\subsubsection{SMA Mix design No.1B}

One trial prepared with same aggregate blending, shingle and binder content but dust has been replaced with cement Kiln dust to check the properties. The detailed results are mentioned in Table 4.8. From the result and visual examination of the mix, one can conclude that less CKD could have been used and provide adequate result. This would require changing the blending of the aggregates. The CKD is finer than the Baghouse dust and this would require the (CKD) mixes to contain less mineral filler, for gradation of CKD and dust refer to chapter 3 .

Table 4.8 Results for SMA Mix design No.1B

\begin{tabular}{|l|c|}
\hline \multicolumn{1}{|c|}{ Parameter } & Result \\
\hline $\begin{array}{l}\text { Binder Content (\%) including from } \\
\text { Shingles }\end{array}$ & 5.5 \\
\hline Maximum Relative Density & 2.614 \\
\hline Bulk Relative Density & 2.514 \\
\hline$\%$ Gmm @ $\mathrm{N}_{\text {(initial) }}$ & 85.9 \\
\hline$\%$ Gmm @ $\mathrm{N}_{(\text {design) }}$ & 96.35 \\
\hline Air Voids (\%) $\mathrm{N}_{\text {(design) }}$ & 3.65 \\
\hline VMA (\%) & 17.17 \\
\hline VFA (\%) & 79.5 \\
\hline
\end{tabular}

\subsubsection{Check of Mix design}

The mixture was checked for compliance with the stability and flow as per Marshall Mix design. The objective is to see the effect of the hardened binder from the tear off shingles on the flow of the mixture. Results are in Table 4.9 and Table 4.10 
Table 4.9 Gradation of extracted mix with respect to my blend and target limit is formulated for SMA Mix design No.1

\begin{tabular}{|c|c|c|c|c|c|c|}
\hline \multicolumn{7}{|c|}{ Sieve Analysis Sheet } \\
\hline \multicolumn{7}{|c|}{ Type of Material SMA Mix } \\
\hline \multicolumn{2}{|c|}{$\begin{array}{c}\text { TOTAL WEIGHT OF } \\
\text { MATERIAL }\end{array}$} & \multicolumn{5}{|c|}{2026.7} \\
\hline \multicolumn{2}{|c|}{ Extracted Binder Content } & \multicolumn{5}{|c|}{5.466} \\
\hline & & & & & $\begin{array}{r}\text { Targe } \\
\text { OF } \\
31354 \\
2\end{array}$ & $\begin{array}{l}\text { As per } \\
\text { is } \\
\text { U May } \\
2\end{array}$ \\
\hline $\begin{array}{l}\text { SIEVE } \\
\text { SIZES }\end{array}$ & $\begin{array}{c}\text { Cumulative } \\
\text { Mass } \\
\text { Retained }\end{array}$ & $\begin{array}{l}\text { Percent } \\
\text { Retained }\end{array}$ & $\begin{array}{c}\text { Extracted } \\
\text { Percent } \\
\text { Passing }\end{array}$ & Blend & $\begin{array}{l}\text { Lower } \\
\text { Limit }\end{array}$ & $\begin{array}{l}\text { Upper } \\
\text { Limit }\end{array}$ \\
\hline $16.0 \mathrm{~mm}$ & 0.00 & 0.00 & 100.00 & 100.00 & 100 & 100 \\
\hline $13.2 \mathrm{~mm}$ & 15.50 & 0.76 & 99.24 & 99.49 & 90 & 100 \\
\hline $9.5 \mathrm{~mm}$ & 412.40 & 20.35 & 79.65 & 76.72 & 50 & 85 \\
\hline $6.7 \mathrm{~mm}$ & 1032.40 & 50.94 & 49.06 & 45.75 & 35 & 62.5 \\
\hline $4.75 \mathrm{~mm}$ & 1360.80 & 67.14 & 32.86 & 30.01 & 20 & 40 \\
\hline $2.36 \mathrm{~mm}$ & 1532.00 & 75.59 & 24.41 & 21.62 & 16 & 28 \\
\hline $1.18 \mathrm{~mm}$ & 1618.20 & 79.84 & 20.16 & 17.48 & 14 & 25 \\
\hline $0.600 \mathrm{~mm}$ & 1682.40 & 83.01 & 16.99 & 14.91 & 12 & 20 \\
\hline $0.300 \mathrm{~mm}$ & 1728.70 & 85.30 & 14.70 & 13.06 & 10 & 15 \\
\hline $0.150 \mathrm{~mm}$ & 1779.00 & 87.78 & 12.22 & 11.52 & 9 & 12 \\
\hline $0.075 \mathrm{~mm}$ & 1828.00 & 90.20 & 9.80 & 9.59 & 8 & 11 \\
\hline
\end{tabular}

Table 4.10 Results of Stability and Flow

\begin{tabular}{|c|c|c|c|c|}
\hline $\begin{array}{c}\text { Specimen } \\
\text { Number }\end{array}$ & 1 & 2 & 3 & Average \\
\hline Stability (lbs) & 14750 & 14500 & 14000 & 14416.7 \\
\hline Flow (mm) & 8.5 & 10 & 9.5 & 9.33 \\
\hline
\end{tabular}




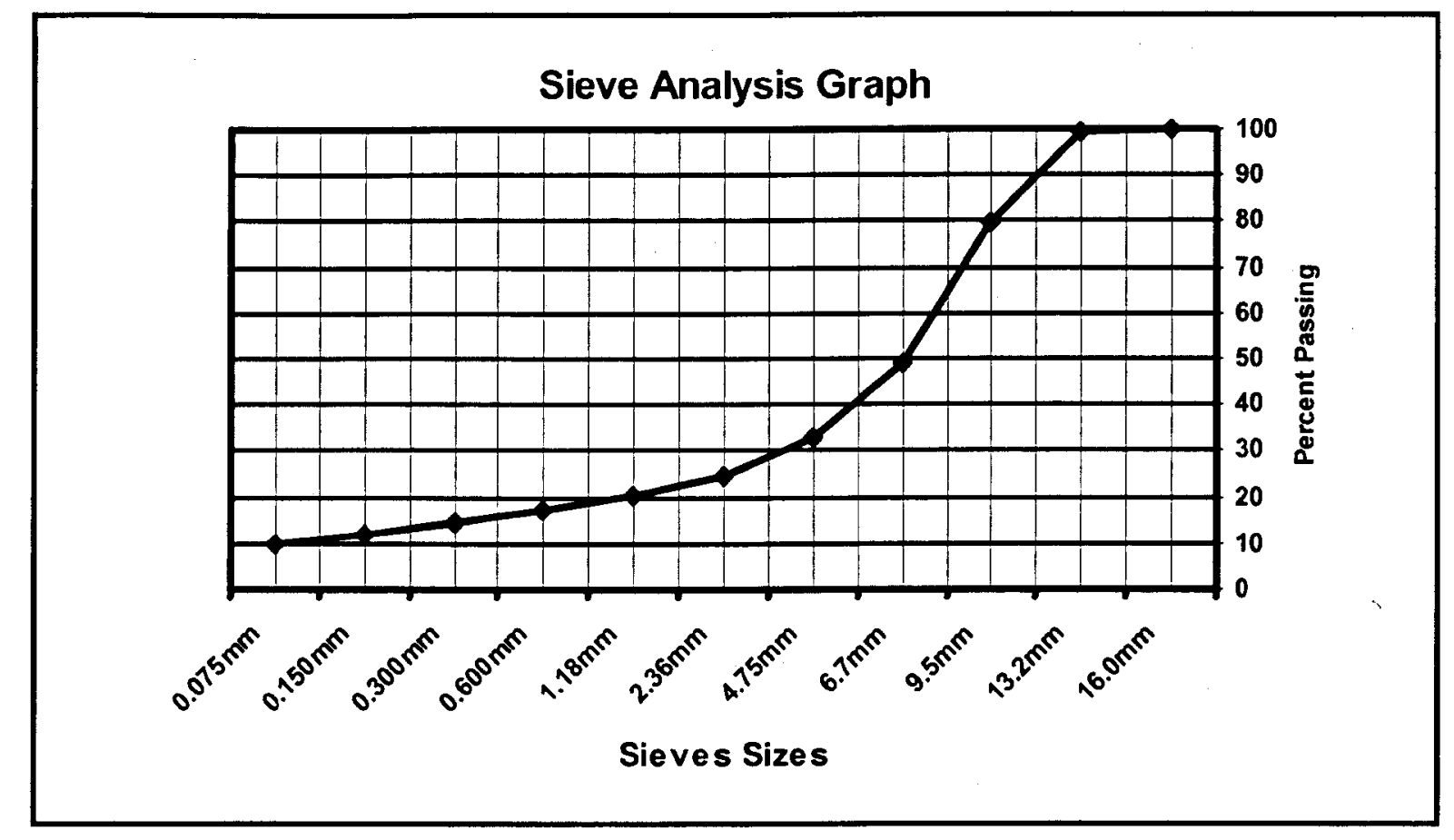

Figure 4.6 Extracted materials graph of SMA mix No.1 


\subsubsection{SMA Mix design No.2}

SMA Mix design with $3 \%$ tear off shingles, $78 \%$ coarse aggregate, $7 \%$ dust and $12 \%$ fine aggregate prepared to compare the results with $5 \%$ shingles the results and properties are given in appendix A to C. Some properties are given in Table 4.11

Table 4.11 Results for SMA Mix design No.2

\begin{tabular}{||l|c|c|c||}
\hline \multicolumn{1}{|c|}{ Parameter } & \multicolumn{3}{|c||}{ Results } \\
\hline $\begin{array}{l}\text { Binder Content (\%)including } \\
\text { from Shingles }\end{array}$ & 5.0 & 5.5 & 5.9 \\
\hline Maximum Relative Density & 2.640 & 2.622 & 2.559 \\
\hline Bulk Relative Density & 2.498 & 2.518 & 2.528 \\
\hline$\%$ Gmm @ $\mathrm{N}_{\text {(initial) }}$ & 83.8 & 86.0 & 86.6 \\
\hline$\%$ Gmm @ $\mathrm{N}_{\text {(design) }}$ & 94.6 & 96.0 & 97.6 \\
\hline Air Voids (\%) $\mathrm{N}_{\text {(design) }}$ & 5.4 & 4.0 & 2.4 \\
\hline VMA (\%) & 17.3 & 17.0 & 17.10 \\
\hline $\begin{array}{l}\text { VFA (\%) } \\
\text { Tensile Strength Ratio (\%) at } \\
\text { optimum binder content }\end{array}$ & 68.8 & 76.5 & 86.0 \\
\hline $\begin{array}{l}\text { Draindown(\%) at Optimum } \\
\text { Binder content }\end{array}$ & & 84.65 \\
\hline \hline
\end{tabular}


Table 4.12 Aggregate blending for SMA mix design No.1B containing 5\% shingles but dust has replaced with CKD

\begin{tabular}{|c|c|c|c|c|c|c|c|c|c|c|c|}
\hline \multicolumn{12}{|c|}{ AGGREGATE BLENDING SHEET } \\
\hline Material & \multicolumn{2}{|c|}{ MRT COARSE } & \multicolumn{2}{|c|}{$\begin{array}{l}\text { MRT Washed } \\
\text { Screening }\end{array}$} & \multicolumn{2}{|c|}{ SHINGLES } & \multicolumn{2}{|c|}{ CKD } & \multirow[b]{3}{*}{$\begin{array}{l}\text { Blend } \\
\text { \%age }\end{array}$} & \multirow{2}{*}{\multicolumn{2}{|c|}{$\begin{array}{c}\text { Target as per } \\
\text { OPSS\#.313S45M May } \\
2002\end{array}$}} \\
\hline$\%$ Used & 78 & & & & 5 & & 74 & & & & \\
\hline $\begin{array}{c}\text { Sieves in } \\
\mathrm{mm}\end{array}$ & $\begin{array}{c}\% \\
\text { Passing }\end{array}$ & $\begin{array}{c}\% \\
\text { Batch } \\
\end{array}$ & $\begin{array}{c}\% \\
\text { Passing }\end{array}$ & $\begin{array}{c}\% \\
\text { Batch }\end{array}$ & $\begin{array}{c}\% \\
\text { Passing }\end{array}$ & $\begin{array}{c}\% \\
\text { Batch }\end{array}$ & $\begin{array}{c}\% \\
\text { Passing }\end{array}$ & $\begin{array}{c}\% \\
\text { Batch }\end{array}$ & & $\begin{array}{c}\text { Lower } \\
\text { Limit }\end{array}$ & $\begin{array}{l}\text { Upper } \\
\text { Limit }\end{array}$ \\
\hline 26.5 & 100.00 & 78.00 & 100.00 & 10.00 & 100.00 & 5.00 & 100.00 & 7.00 & 100.00 & 100 & 100 \\
\hline 19.0 & 100.00 & 78.00 & 100.00 & 10.00 & 100.00 & 5.00 & 100.00 & 7.00 & 100.00 & 100 & 100 \\
\hline 16.0 & 100.00 & 78.00 & 100.00 & 10.00 & 100.00 & 5.00 & 100.00 & 7.00 & 100.00 & 100 & 100 \\
\hline 13.2 & 99.60 & 77.69 & 100.00 & 10.00 & 96.13 & 4.81 & 100.00 & 7.00 & 99.49 & 90 & 100 \\
\hline 9.5 & 71.10 & 55.46 & 100.00 & 10.00 & 85.25 & 4.26 & 100.00 & 7.00 & 76.72 & 50 & 85 \\
\hline 6.7 & 31.80 & 24.80 & 100.00 & 10.00 & 78.82 & 3.94 & 100.00 & 7.00 & 45.75 & 35 & 62.5 \\
\hline 4.75 & 12.50 & 9.75 & 95.21 & 9.52 & 74.81 & 3.74 & 100.00 & 7.00 & 30.01 & 20 & 40 \\
\hline 2.36 & 5.80 & 4.52 & 67.60 & 6.76 & 66.81 & 3.34 & 100.00 & 7.00 & 21.62 & 16 & 28 \\
\hline 1.18 & 4.50 & 3.51 & 46.47 & 4.65 & 46.50 & 2.33 & 100.00 & 7.00 & 17.48 & 14 & 25 \\
\hline 0.600 & 3.70 & 2.89 & 33.81 & 3.38 & 32.89 & 1.64 & 99.76 & 6.98 & 14.89 & 12 & 20 \\
\hline 0.300 & 3.00 & 2.34 & 22.83 & 2.28 & 28.68 & 1.43 & 99.46 & 6.96 & 13.02 & 10 & 15 \\
\hline 0.150 & 2.30 & 1.79 & 14.89 & 1.5 & 24.68 & 1.2 & 99.24 & 6.9 & 11.46 & 9 & 12 \\
\hline 0.075 & 1.51 & 1.18 & 5.99 & 0.6 & 21.96 & 1.1 & 86.00 & 6.0 & 8.89 & 8 & 11 \\
\hline
\end{tabular}


SNISS $\forall d \perp N \exists O Y \exists d$

ㅇㅇㅇㅇㅇ 요유 유 웅

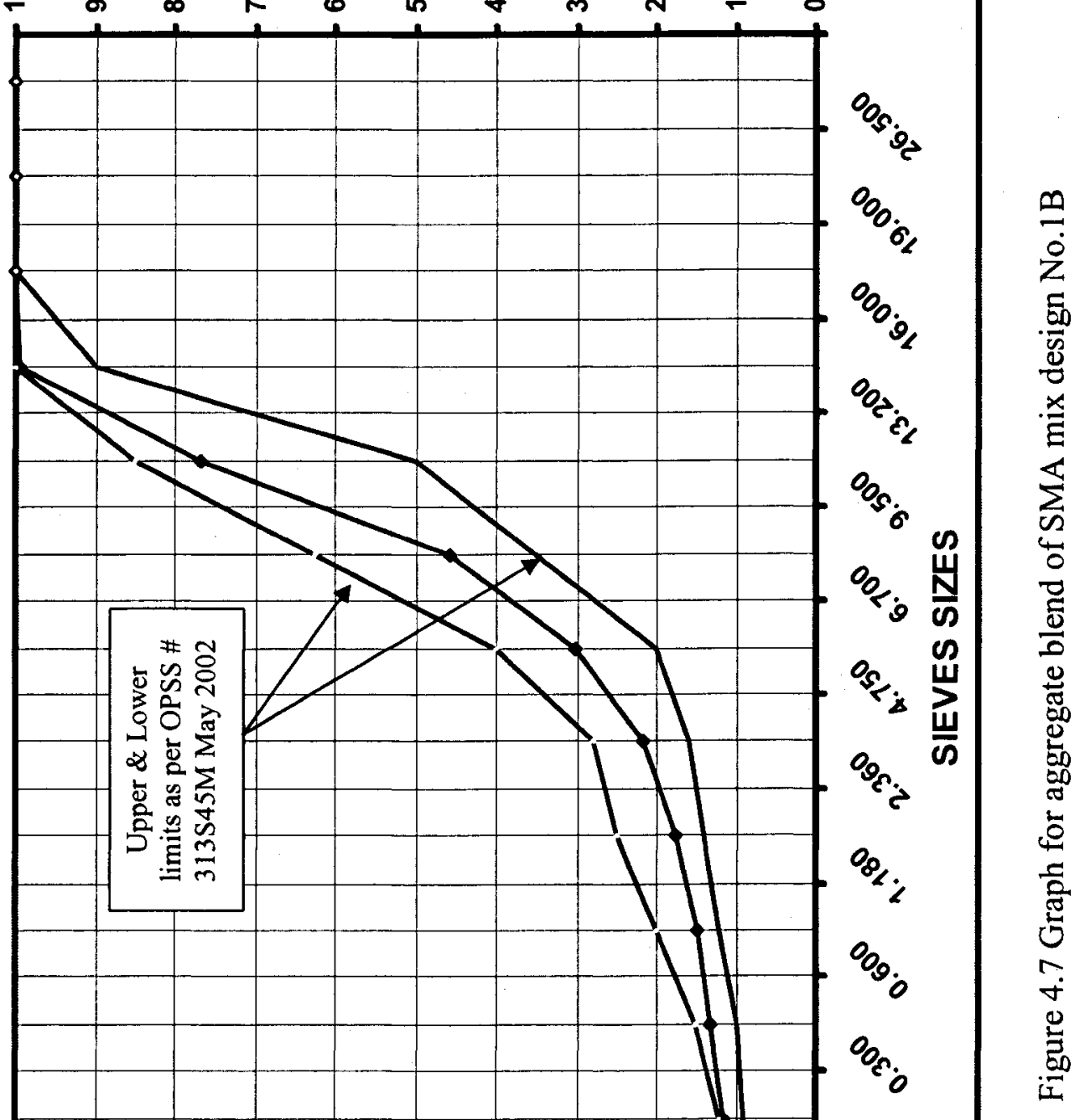


Table No.4.13 Aggregate blending for SMA Mix design No.2

\begin{tabular}{|c|c|c|c|c|c|c|c|c|c|c|c|}
\hline \multicolumn{12}{|c|}{ AGGREGATE BLENDING SHEET } \\
\hline Material & \multicolumn{2}{|c|}{ MRT COARSE } & \multicolumn{2}{|c|}{$\begin{array}{l}\text { MRT Washed } \\
\text { Screening }\end{array}$} & \multicolumn{2}{|c|}{ SHINGLES } & \multirow{2}{*}{\multicolumn{2}{|c|}{$\frac{\text { DUST }}{7 \%}$}} & \multirow[b]{3}{*}{$\begin{array}{l}\text { Blend } \\
\text { \%age }\end{array}$} & \multirow{2}{*}{\multicolumn{2}{|c|}{$\begin{array}{c}\text { Target as per } \\
\text { OPSS\#.313S45M May } \\
2002\end{array}$}} \\
\hline$\%$ Used & $78^{\circ}$ & & 14 & & & & & & & & \\
\hline $\begin{array}{c}\text { Sieves in } \\
\mathrm{mm}\end{array}$ & $\begin{array}{c}\% \\
\text { Passing } \\
\end{array}$ & $\begin{array}{c}\% \\
\text { Batch } \\
\end{array}$ & $\begin{array}{c}\% \\
\text { Passing } \\
\end{array}$ & $\begin{array}{c}\% \\
\text { Batch } \\
\end{array}$ & $\begin{array}{c}\% \\
\text { Passing } \\
\end{array}$ & $\begin{array}{c}\% \\
\text { Batch } \\
\end{array}$ & $\begin{array}{c}\% \\
\text { Passing } \\
\end{array}$ & $\begin{array}{c}\% \\
\text { Batch } \\
\end{array}$ & & Lower Limit & $\begin{array}{l}\text { Upper } \\
\text { Limit }\end{array}$ \\
\hline 26.5 & 100.00 & 78.00 & 100.00 & 14.00 & 100.00 & 3.00 & 100.00 & 7.00 & 102.00 & 100 & 100 \\
\hline 19.0 & 100.00 & 78.00 & 100.00 & 14.00 & 100.00 & 3.00 & 100.00 & 7.00 & 102.00 & 100 & 100 \\
\hline 16.0 & 100.00 & 78.00 & 100.00 & 14.00 & 100.00 & 3.00 & 100.00 & 7.00 & 102.00 & 100 & 100 \\
\hline 13.2 & 99.60 & 77.69 & 100.00 & 14.00 & 96.13 & 2.88 & 100.00 & 7.00 & 101.57 & 90 & 100 \\
\hline 9.5 & 71.10 & 55.46 & 100.00 & 14.00 & 85.25 & 2.56 & 100.00 & 7.00 & 79.02 & 50 & 85 \\
\hline 6.7 & 31.80 & 24.80 & 100.00 & 14.00 & 78.82 & 2.36 & 100.00 & 7.00 & 48.17 & 35 & 62.5 \\
\hline 4.75 & 12.50 & 9.75 & 95.21 & 13.33 & 74.81 & 2.24 & 100.00 & 7.00 & 32.32 & 20 & 40 \\
\hline 2.36 & 5.80 & 4.52 & 67.60 & 9.46 & 66.81 & 2.00 & 100.00 & 7.00 & 22.99 & 16 & 28 \\
\hline 1.18 & 4.50 & 3.51 & 46.47 & 6.51 & 46.50 & 1.40 & 100.00 & 7.00 & 18.41 & 14 & 25 \\
\hline 0.600 & 3.70 & 2.89 & 33.81 & 4.73 & 32.89 & 0.99 & 99.76 & 6.98 & 15.59 & 12 & 20 \\
\hline 0.300 & 3.00 & 2.34 & 22.83 & 3.20 & 28.68 & 0.86 & 99.46 & 6.96 & 13.36 & 10 & 15 \\
\hline 0.150 & 2.30 & 1.79 & 14.89 & 2.1 & 24.68 & 0.7 & 99.24 & 6.9 & 11.57 & 9 & 12 \\
\hline 0.075 & 1.51 & 1.18 & 5.99 & 0.8 & 21.96 & 0.7 & 86.00 & 6.0 & 8.70 & 8 & 11 \\
\hline
\end{tabular}




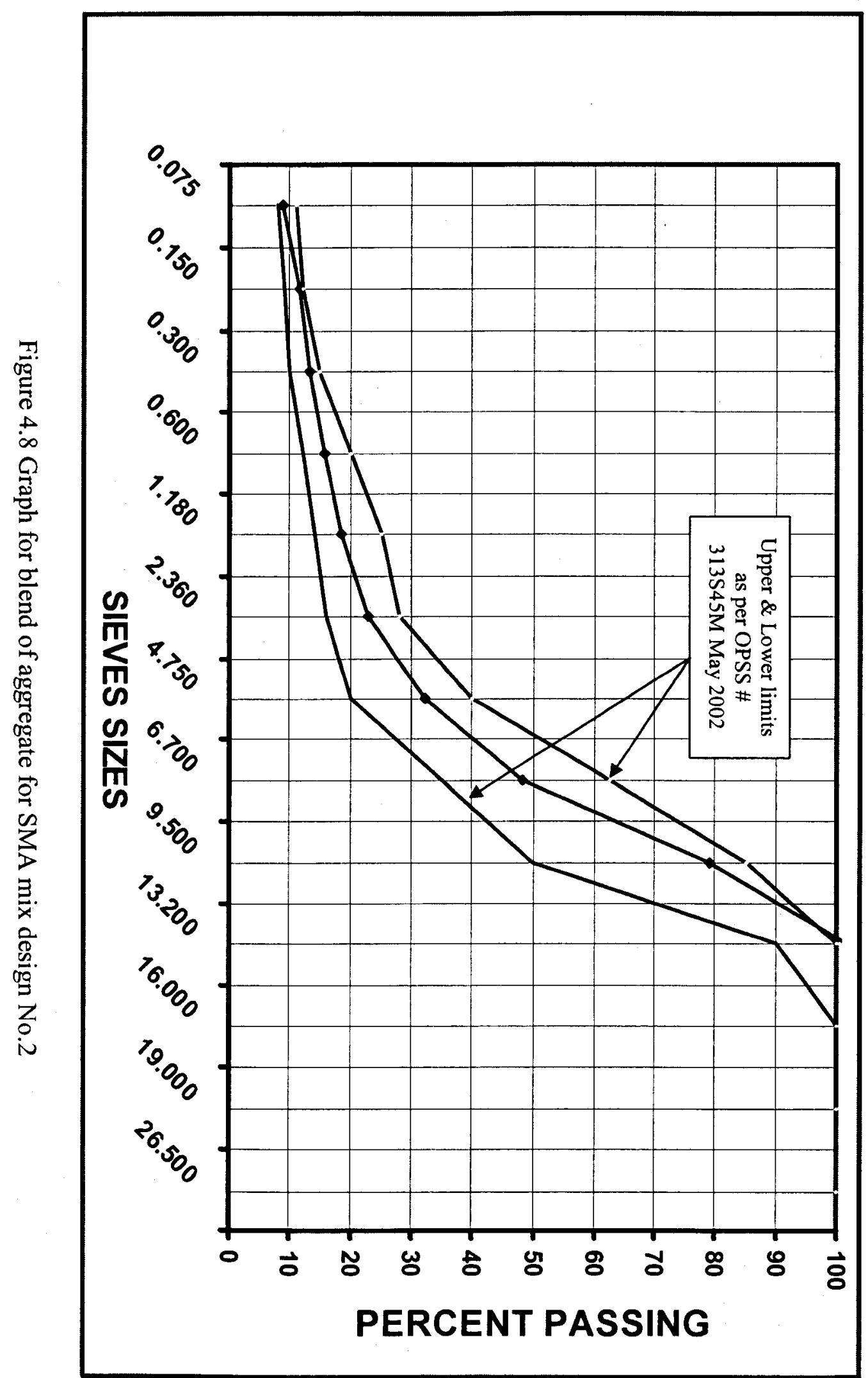


Figure 4.9 Property Curves for SMA mix design No.2

Binder Content VS Bulk Relative Density

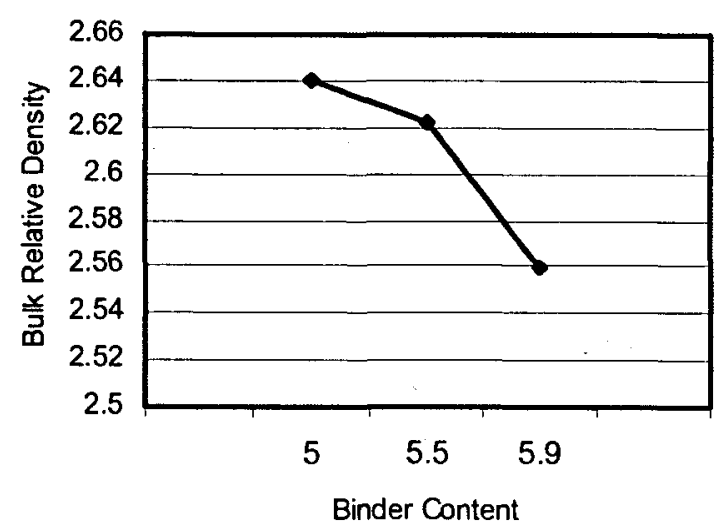

Binder Content VS Air Voids

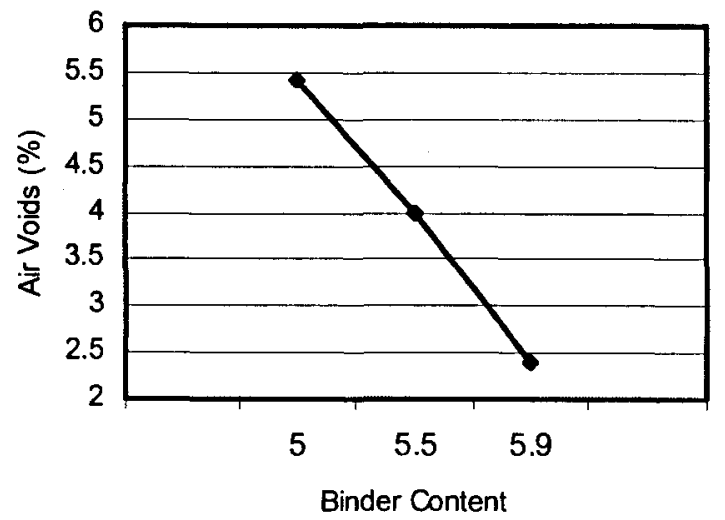

Binder Content VS \% Gmm @ N(design)

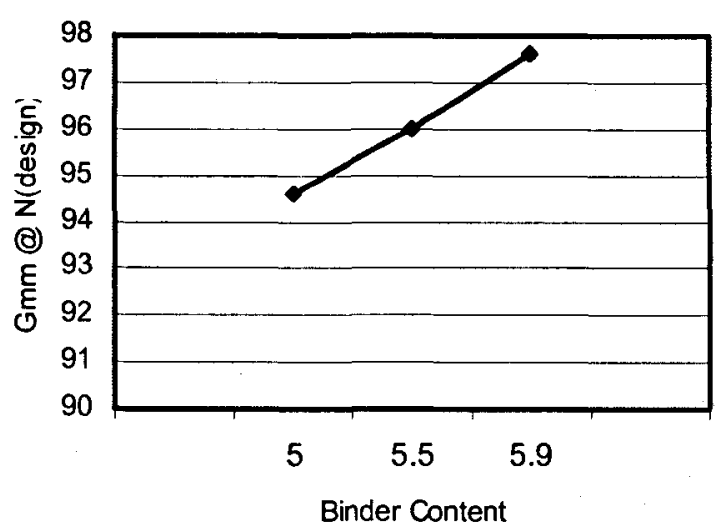

Binder Content VS VFA

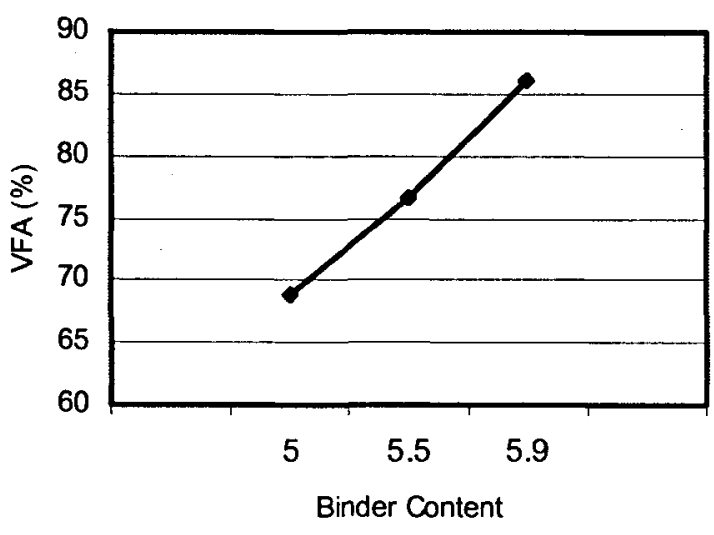




\subsubsection{SMA Mix design No.3}

SMA Mix design with $0.6 \%$ fibers, $78 \%$ coarse aggregate, $15 \%$ fine aggregate and $7 \%$ dust has prepared to compare the results with $5 \%$ shingles the results and properties are given in appendix A to C. Some properties are given in Table 4.14

Table 4.14 Results for SMA mix design No.3

\begin{tabular}{|c|c|c|c|}
\hline Parameter & \multicolumn{3}{|c|}{ Results } \\
\hline Binder Content ( $\%)$ & 5.5 & 6.0 & 6.5 \\
\hline Maximum Relative Density & 2.642 & 2.618 & 2.599 \\
\hline Bulk Relative Density & 2.498 & 2.512 & 2.520 \\
\hline$\% \mathrm{Gmm} @ \mathrm{~N}_{\text {(initial) }}$ & 83.5 & 86.0 & 86.5 \\
\hline$\% \mathrm{Gmm} @ \mathrm{~N}_{(\text {design })}$ & 94.5 & .96 .0 & 97.0 \\
\hline Air Voids $(\%) \mathrm{N}_{(\mathrm{design})}$ & 5.5 & 4.0 & 3.0 \\
\hline VMA $(\%)$ & 17.74 & 17.66 & 17.85 \\
\hline VFA (\%) & 77.35 & 83.19 & 86.66 \\
\hline $\begin{array}{l}\text { Tensile Strength Ratio (\%) at } \\
\text { optimum binder content }\end{array}$ & \multicolumn{3}{|c|}{86.2} \\
\hline $\begin{array}{l}\text { Draindown( }(\%) \text { at Optimum } \\
\text { Binder content }\end{array}$ & \multicolumn{3}{|c|}{0.0} \\
\hline
\end{tabular}


Table 4.15 Aggregate blending for SMA Mix design No.3 which contains $0.6 \%$ fibers in place of shingles

\begin{tabular}{|c|c|c|c|c|c|c|c|c|c|}
\hline \multicolumn{10}{|c|}{ AGGREGATE BLENDING SHEET } \\
\hline$\frac{\text { Material }}{\% \text { Used }}$ & \multicolumn{2}{|c|}{ MRT COARSE } & \multicolumn{2}{|c|}{$\begin{array}{c}\text { MRT Washed } \\
\text { Screening } \\
15 \%\end{array}$} & \multicolumn{2}{|c|}{$\frac{\text { DUST }}{7 \%}$} & \multirow[b]{2}{*}{$\begin{array}{l}\text { Blend } \\
\text { \%age }\end{array}$} & \multicolumn{2}{|c|}{$\begin{array}{c}\text { Target as per } \\
\text { OPSS\#.313S45M May } \\
2002\end{array}$} \\
\hline $\begin{array}{c}\text { Sieves in } \\
\mathrm{mm}\end{array}$ & $\begin{array}{c}\% \\
\text { Passing } \\
\end{array}$ & $\begin{array}{c}\% \\
\text { Batch }\end{array}$ & $\begin{array}{c}\% \\
\text { Passing }\end{array}$ & $\begin{array}{c}\% \\
\text { Batch }\end{array}$ & $\begin{array}{c}\% \\
\text { Passing }\end{array}$ & $\begin{array}{c}\% \\
\text { Batch }\end{array}$ & & $\begin{array}{c}\text { Lower } \\
\text { Limit }\end{array}$ & $\begin{array}{l}\text { Upper } \\
\text { Limit }\end{array}$ \\
\hline 26.5 & 100.00 & 78.00 & 100.00 & 15.00 & 100.00 & 7.00 & 100.00 & 100 & 100 \\
\hline 19.0 & 100.00 & 78.00 & 100.00 & 15.00 & 100.00 & 7.00 & 100.00 & 100 & 100 \\
\hline 16.0 & 100.00 & 78.00 & 100.00 & 15.00 & 100.00 & 7.00 & 100.00 & 100 & 100 \\
\hline 13.2 & 99.60 & 77.69 & 100.00 & 15.00 & 100.00 & 7.00 & 99.69 & 90 & 100 \\
\hline 9.5 & 71.10 & 55.46 & 100.00 & 15.00 & 100.00 & 7.00 & 77.46 & 50 & 85 \\
\hline 6.7 & 31.80 & 24.80 & 100.00 & 15.00 & 100.00 & 7.00 & 46.80 & 35 & 62.5 \\
\hline 4.75 & 12.50 & 9.75 & 95.21 & 14.28 & 100.00 & 7.00 & 31.03 & 20 & 40 \\
\hline 2.36 & 5.80 & 4.52 & 67.60 & 10.14 & 100.00 & 7.00 & 21.66 & 16 & 28 \\
\hline 1.18 & 4.50 & 3.51 & 46.47 & 6.97 & 100.00 & 7.00 & 17.48 & 14 & 25 \\
\hline 0.600 & 3.70 & 2.89 & 33.81 & 5.07 & 99.76 & 6.98 & 14.94 & 12 & 20 \\
\hline 0.300 & 3.00 & 2.34 & 22.83 & 3.42 & 99.46 & 6.96 & 12.73 & 10 & 15 \\
\hline 0.150 & 2.30 & 1.79 & 14.89 & 2.2 & 99.24 & 6.9 & 10.97 & 9 & 12 \\
\hline 0.075 & 1.51 & 1.18 & 5.99 & 0.9 & 86.00 & 6.0 & 8.10 & 8 & 11 \\
\hline
\end{tabular}




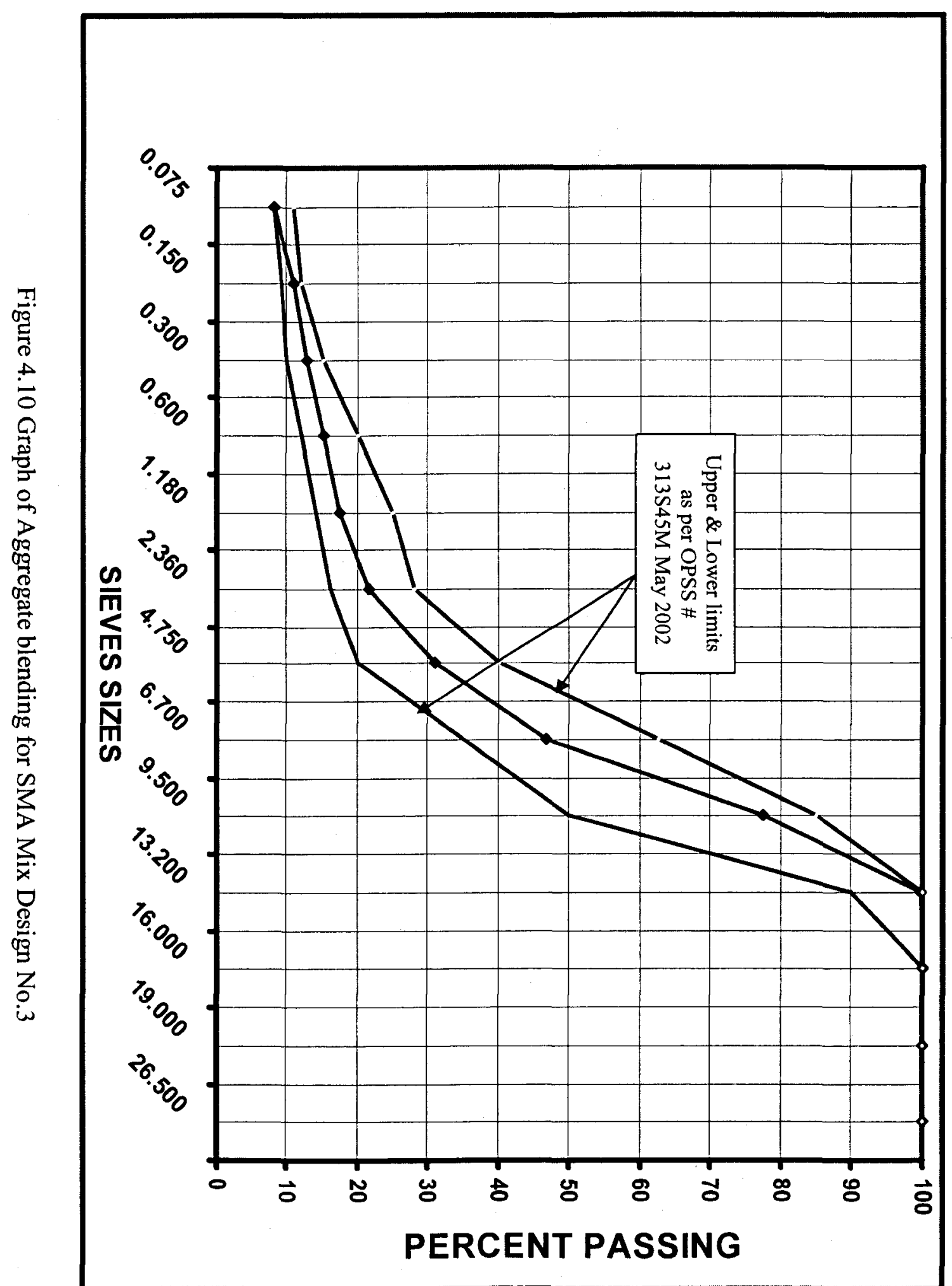


Figure 4.11Property Curves for SMA mix design No.3

Binder Content VS Bulk Relative Density

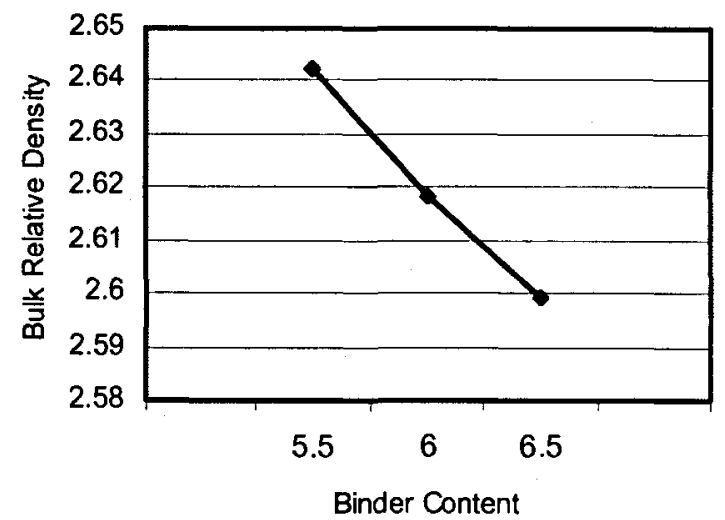

Binder Content VS Air Voids

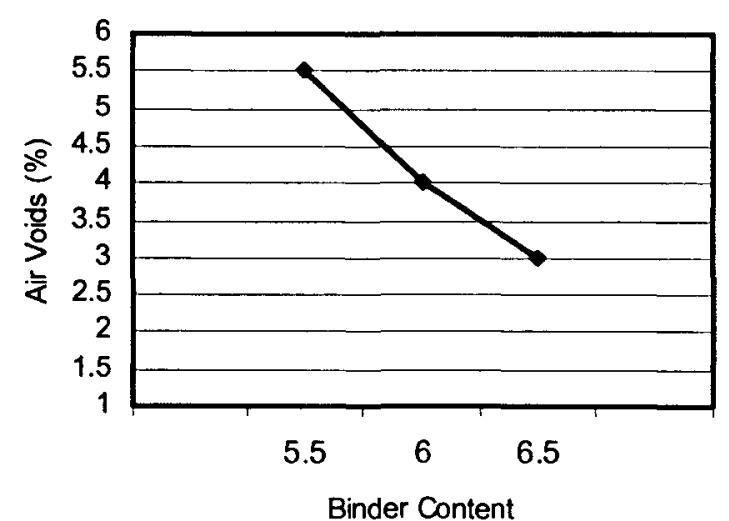

Binder Content VS \% Gmm@N(design)

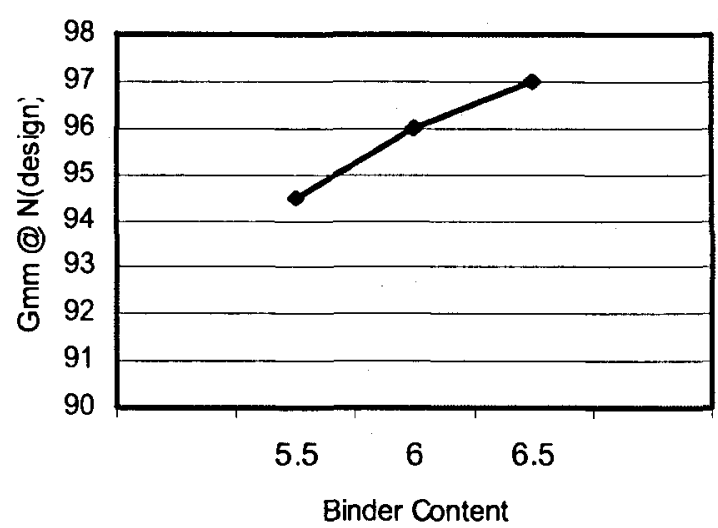

Binder Content VS VFA

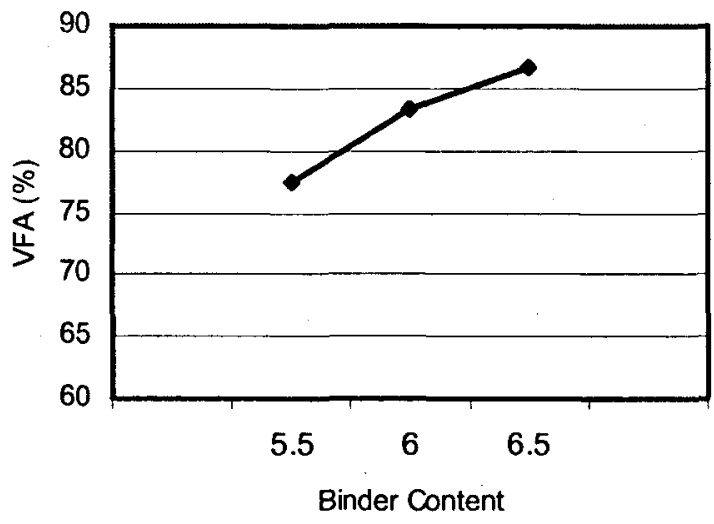




\subsubsection{SMA Mix design No.4}

SMA Mix design with 0.3 fibers, $78 \%$ coarse aggregate, $15 \%$ fine aggregate and $7 \%$ dust has prepared to compare the results with $5 \%$ shingles the results and properties are given in appendix A to $\mathrm{C}$. Some properties are given in Table 4.16

Table 4.16Results for SMA Mix design No.4

\begin{tabular}{||l|c|c|c||}
\hline \multicolumn{1}{|c|}{ Parameter } & \multicolumn{3}{c||}{ Results } \\
\hline Binder Content (\%) & 5.2 & 5.7 & 6.2 \\
\hline Maximum Relative Density & 2.640 & 2.617 & 2.599 \\
\hline Bulk Relative Density & 2.482 & 2.513 & 2.599 \\
\hline$\%$ Gmm @ $\mathrm{N}_{(\text {initial) }}$ & 82.4 & 86.0 & 86.3 \\
\hline$\%$ Gmm @ N $\mathrm{N}_{(\text {design) }}$ & 94.0 & 96.0 & 96.7 \\
\hline $\begin{array}{l}\text { Air Voids (\%) N(design) } \\
\text { VMA (\%) }\end{array}$ & 6.0 & 4.0 & 3.3 \\
\hline $\begin{array}{l}\text { VFA (\%) } \\
\text { Tensile Strength Ratio (\%) at } \\
\text { optimum binder content }\end{array}$ & 18.0 & 17.4 & 17.8 \\
\hline $\begin{array}{l}\text { Draindown(\%) at Optimum } \\
\text { Binder content }\end{array}$ & 66.7 & 77.0 & 81.5 \\
\hline
\end{tabular}


Table 4.17Aggregate blending for SMA Mix design No.4 which contains $0.3 \%$ fibers in place of shingles

\begin{tabular}{|c|c|c|c|c|c|c|c|c|c|}
\hline \multicolumn{10}{|c|}{ AGGREGATE BLENDING SHEET } \\
\hline Material & \multicolumn{2}{|c|}{ MRT COARSE } & \multicolumn{2}{|c|}{$\begin{array}{l}\text { MRT Washed } \\
\text { Screening }\end{array}$} & \multicolumn{2}{|c|}{ DUST } & \multirow[b]{3}{*}{$\begin{array}{l}\text { Blend } \\
\text { \%age }\end{array}$} & \multirow{2}{*}{\multicolumn{2}{|c|}{$\begin{array}{c}\text { Target as per } \\
\text { OPSS\#.313S45M May } \\
2002\end{array}$}} \\
\hline$\%$ Used & 18 & & & & & & & & \\
\hline $\begin{array}{c}\text { Sieves in } \\
\mathrm{mm}\end{array}$ & $\begin{array}{c}\% \\
\text { Passing }\end{array}$ & $\begin{array}{c}\% \\
\text { Batch }\end{array}$ & $\begin{array}{c}\% \\
\text { Passing }\end{array}$ & $\begin{array}{c}\% \\
\text { Batch }\end{array}$ & $\begin{array}{c}\% \\
\text { Passing }\end{array}$ & $\begin{array}{c}\% \\
\text { Batch }\end{array}$ & & $\begin{array}{l}\text { Lower } \\
\text { Limit }\end{array}$ & $\begin{array}{l}\text { Upper } \\
\text { Limit }\end{array}$ \\
\hline 26.5 & 100.00 & 78.00 & 100.00 & 15.00 & 100.00 & 7.00 & 100.00 & 100 & 100 \\
\hline 19.0 & 100.00 & 78.00 & 100.00 & 15.00 & 100.00 & 7.00 & 100.00 & 100 & 100 \\
\hline 16.0 & 100.00 & 78.00 & 100.00 & 15.00 & 100.00 & 7.00 & 100.00 & 100 & 100 \\
\hline 13.2 & 99.60 & 77.69 & 100.00 & 15.00 & 100.00 & 7.00 & 99.69 & 90 & 100 \\
\hline 9.5 & 71.10 & 55.46 & 100.00 & 15.00 & 100.00 & 7.00 & 77.46 & 50 & 85 \\
\hline 6.7 & 31.80 & 24.80 & 100.00 & 15.00 & 100.00 & 7.00 & 46.80 & 35 & 62.5 \\
\hline 4.75 & 12.50 & 9.75 & 95.21 & 14.28 & 100.00 & 7.00 & 31.03 & 20 & 40 \\
\hline 2.36 & 5.80 & 4.52 & 67.60 & 10.14 & 100.00 & 7.00 & 21.66 & 16 & 28 \\
\hline 1.18 & 4.50 & 3.51 & 46.47 & 6.97 & 100.00 & 7.00 & 17.48 & 14 & 25 \\
\hline 0.600 & 3.70 & 2.89 & 33.81 & 5.07 & 99.76 & 6.98 & 14.94 & 12 & 20 \\
\hline 0.300 & 3.00 & 2.34 & 22.83 & 3.42 & 99.46 & 6.96 & 12.73 & 10 & 15 \\
\hline 0.150 & 2.30 & 1.79 & 14.89 & 2.2 & 99.24 & 6.9 & 10.97 & 9 & 12 \\
\hline 0.075 & 1.51 & 1.18 & 5.99 & 0.9 & 86.00 & 6.0 & 8.10 & 8 & 11 \\
\hline
\end{tabular}




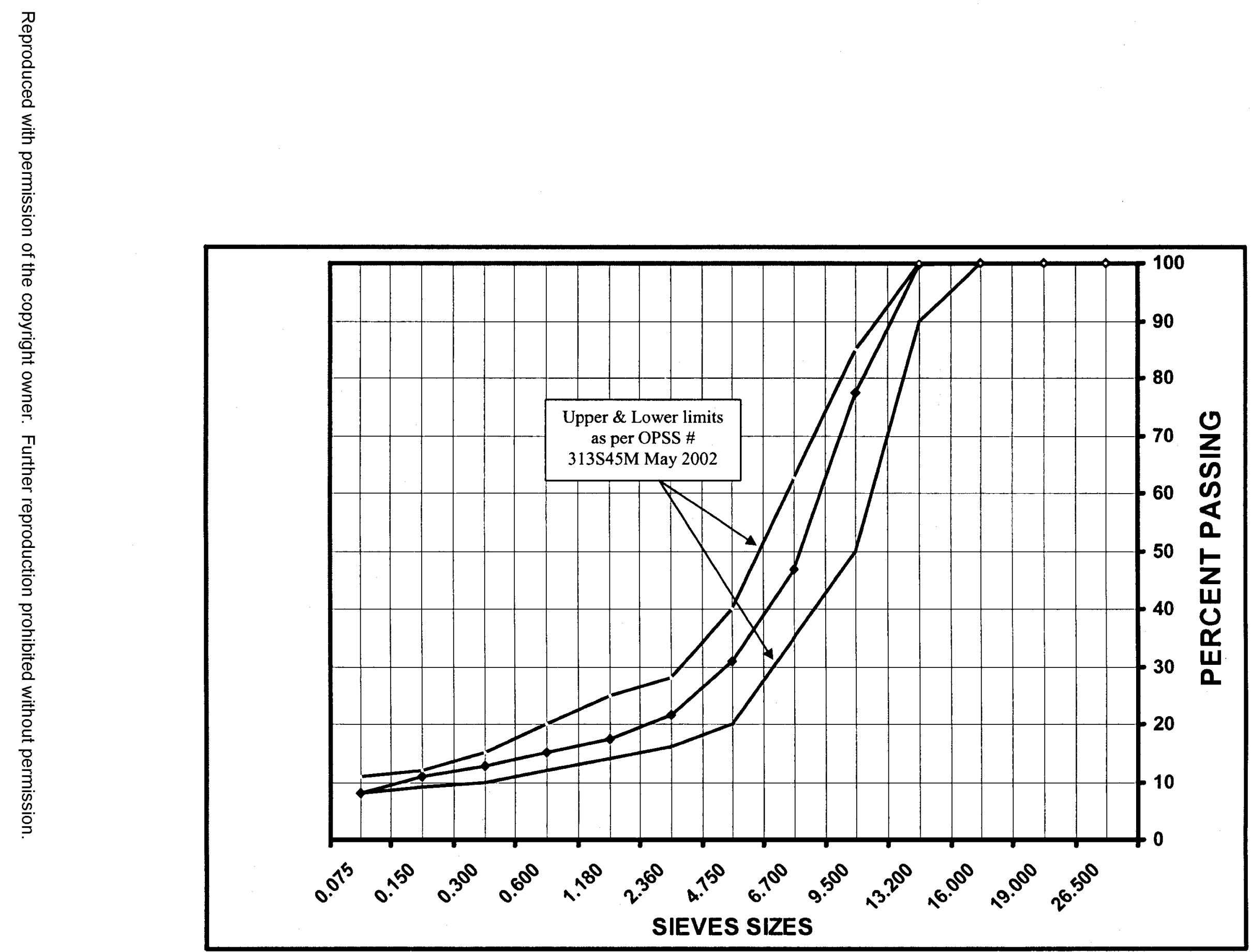

Figure 4.12 Graph of Aggregate blending for SMA Mix design No.4 
Figure 4.13 Property Curves for SMA mix design No.4

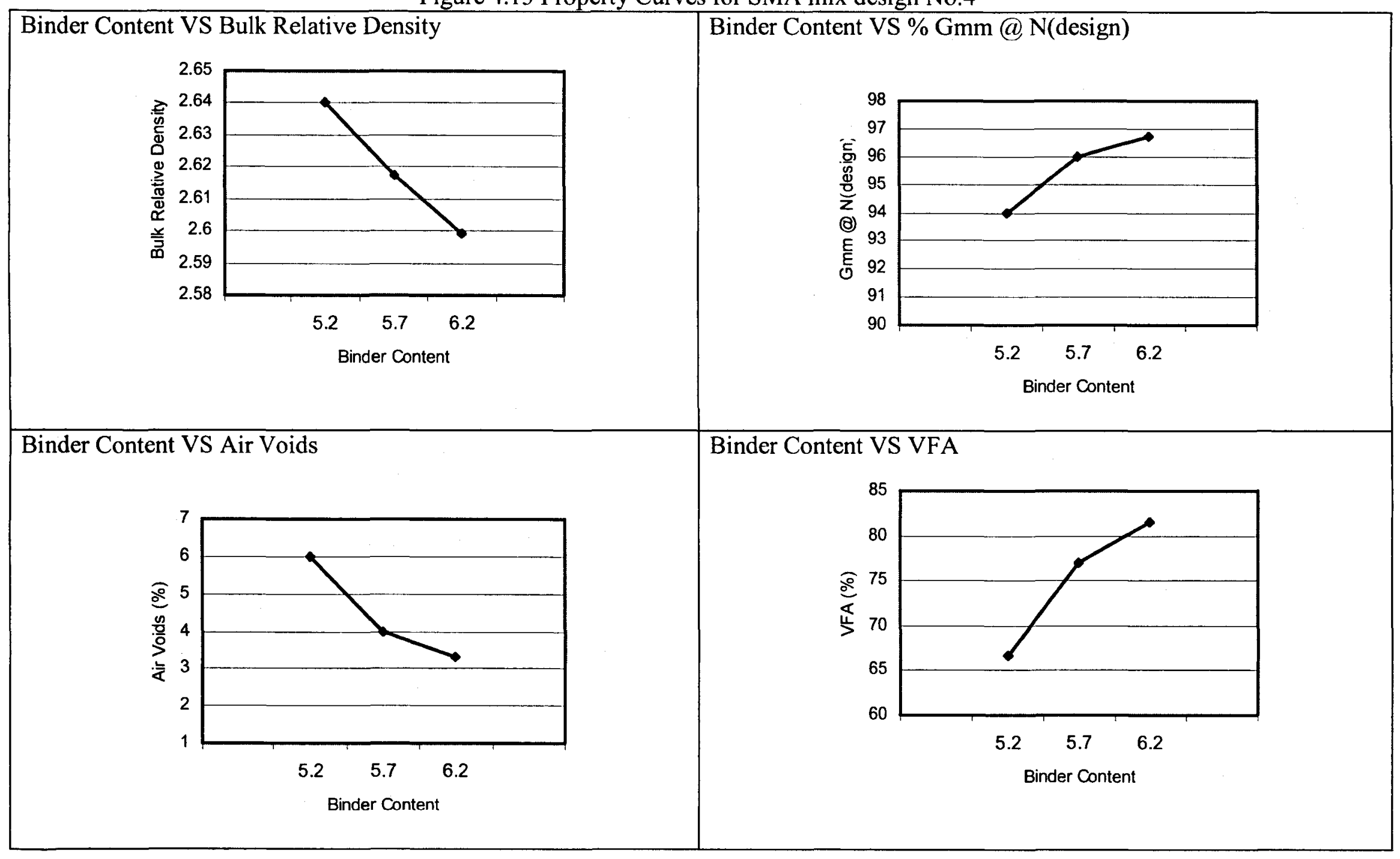




\subsubsection{SMA Mix design No.5}

Three trials of SMA mix design No.5 has been prepared with $10 \%$ of shingles and cement kiln dust to compare the properties with mixes containing dust. Detail results are given in appendix A to C; some properties are given in Table 4.18

Table 4.18 Results for SMA Mix design No.5

\begin{tabular}{||l|c|c|c||}
\hline \multicolumn{1}{|c|}{ Parameter } & \multicolumn{3}{c|}{ Results } \\
\hline $\begin{array}{l}\text { Binder Content (\%) including } \\
\text { from shingles }\end{array}$ & 6.5 & 7.0 & 7.5 \\
\hline Maximum Relative Density & 2.618 & 2.600 & 2.580 \\
\hline Bulk Relative Density & 2.478 & 2.495 & 2.506 \\
\hline$\%$ Gmm @ $\mathrm{N}_{\text {(initial) }}$ & 85 & 86.1 & 86.76 \\
\hline$\%$ Gmm @ $\mathrm{N}_{(\text {design) }}$ & 94.6 & 95.97 & 97.15 \\
\hline Air Voids (\%) $\mathrm{N}_{(\text {design) }}$ & 5.4 & 4.03 & 2.85 \\
\hline VMA (\%) & 18.86 & 19.09 & 17.94 \\
\hline VFA (\%) & 71.37 & 77.4 & 84.11 \\
\hline $\begin{array}{l}\text { Tensile Strength Ratio (\%) at } \\
\text { pptimum binder content }\end{array}$ & & 66.6 \\
\hline $\begin{array}{l}\text { Draindown(\%) at Optimum } \\
\text { Binder content }\end{array}$ & & 0.0 \\
\hline
\end{tabular}

\subsection{Summary of test results}

All results are summarized in Table 4.20 for quick reference 
Table 4.19 Aggregate blending for SMA mix design No.5 which contains CKD in place of Dust

\begin{tabular}{|c|c|c|c|c|c|c|c|c|c|c|c|}
\hline \multicolumn{12}{|c|}{ AGGREGATE BLENDING SHEET } \\
\hline$\frac{\text { Material }}{\% \text { Used }}$ & \multicolumn{2}{|c|}{ MRT COARSE } & \multicolumn{2}{|c|}{$\begin{array}{c}\text { MRT Washed } \\
\text { Screening }\end{array}$} & \multicolumn{2}{|c|}{$\frac{\text { SHINGLES }}{10 \%}$} & \multicolumn{2}{|c|}{$\frac{\text { CKD }}{5 \%}$} & \multirow[b]{2}{*}{$\begin{array}{l}\text { Blend } \\
\text { \%age }\end{array}$} & \multicolumn{2}{|c|}{$\begin{array}{c}\text { Target as per } \\
\text { OPSS\#.313S45M May } \\
2002\end{array}$} \\
\hline $\begin{array}{c}\text { Sieves in } \\
\mathrm{mm}\end{array}$ & $\begin{array}{c}\% \\
\text { Passing }\end{array}$ & $\begin{array}{c}\% \\
\text { Batch }\end{array}$ & $\begin{array}{c}\% \\
\text { Passing }\end{array}$ & $\begin{array}{c}\% \\
\text { Batch }\end{array}$ & $\begin{array}{c}\% \\
\text { Passing }\end{array}$ & $\begin{array}{c}\% \\
\text { Batch }\end{array}$ & $\begin{array}{c}\% \\
\text { Passing }\end{array}$ & $\begin{array}{c}\% \\
\text { Batch }\end{array}$ & & $\begin{array}{c}\text { Lower } \\
\text { Limit }\end{array}$ & $\begin{array}{l}\text { Upper } \\
\text { Limit }\end{array}$ \\
\hline 26.5 & 100.00 & 78.00 & 100.00 & 7.00 & 100.00 & 10.00 & 100.00 & 5.00 & 100.00 & 100 & 100 \\
\hline 19.0 & 100.00 & 78.00 & 100.00 & 7.00 & 100.00 & 10.00 & 100.00 & 5.00 & 100.00 & 100 & 100 \\
\hline 16.0 & 100.00 & 78.00 & 100.00 & 7.00 & 100.00 & 10.00 & 100.00 & 5.00 & 100.00 & 100 & 100 \\
\hline 13.2 & 99.60 & 77.69 & 100.00 & 7.00 & 96.13 & 9.61 & 100.00 & 5.00 & 99.30 & 90 & 100 \\
\hline 9.5 & 71.10 & 55.46 & 100.00 & 7.00 & 85.25 & 8.53 & 100.00 & 5.00 & 75.98 & 50 & 85 \\
\hline 6.7 & 31.80 & 24.80 & 100.00 & 7.00 & 78.82 & 7.88 & 100.00 & 5.00 & 44.69 & 35 & 62.5 \\
\hline 4.75 & 12.50 & 9.75 & 95.21 & 6.66 & 74.81 & 7.48 & 100.00 & 5.00 & 28.90 & 20 & 40 \\
\hline 2.36 & 5.80 & 4.52 & 67.60 & 4.73 & 66.81 & 6.68 & 100.00 & 5.00 & 20.94 & 16 & 28 \\
\hline 1.18 & 4.50 & 3.51 & 46.47 & 3.25 & 46.50 & 4.65 & 100.00 & 5.00 & 16.41 & 14 & 25 \\
\hline 0.600 & 3.70 & 2.89 & 33.81 & 2.37 & 32.89 & 3.29 & 99.76 & 4.99 & 13.53 & 12 & 20 \\
\hline 0.300 & 3.00 & 2.34 & 22.83 & 1.60 & 28.68 & 2.87 & 99.46 & 4.97 & 11.78 & 10 & 15 \\
\hline 0.150 & 2.30 & 1.79 & 14.89 & 1.0 & 24.68 & 2.5 & 99.24 & 5.0 & 10.27 & 9 & 12 \\
\hline 0.075 & 1.51 & 1.18 & 5.99 & 0.4 & 21.96 & 2.2 & 86.00 & 4.3 & 8.09 & 8 & 11 \\
\hline
\end{tabular}




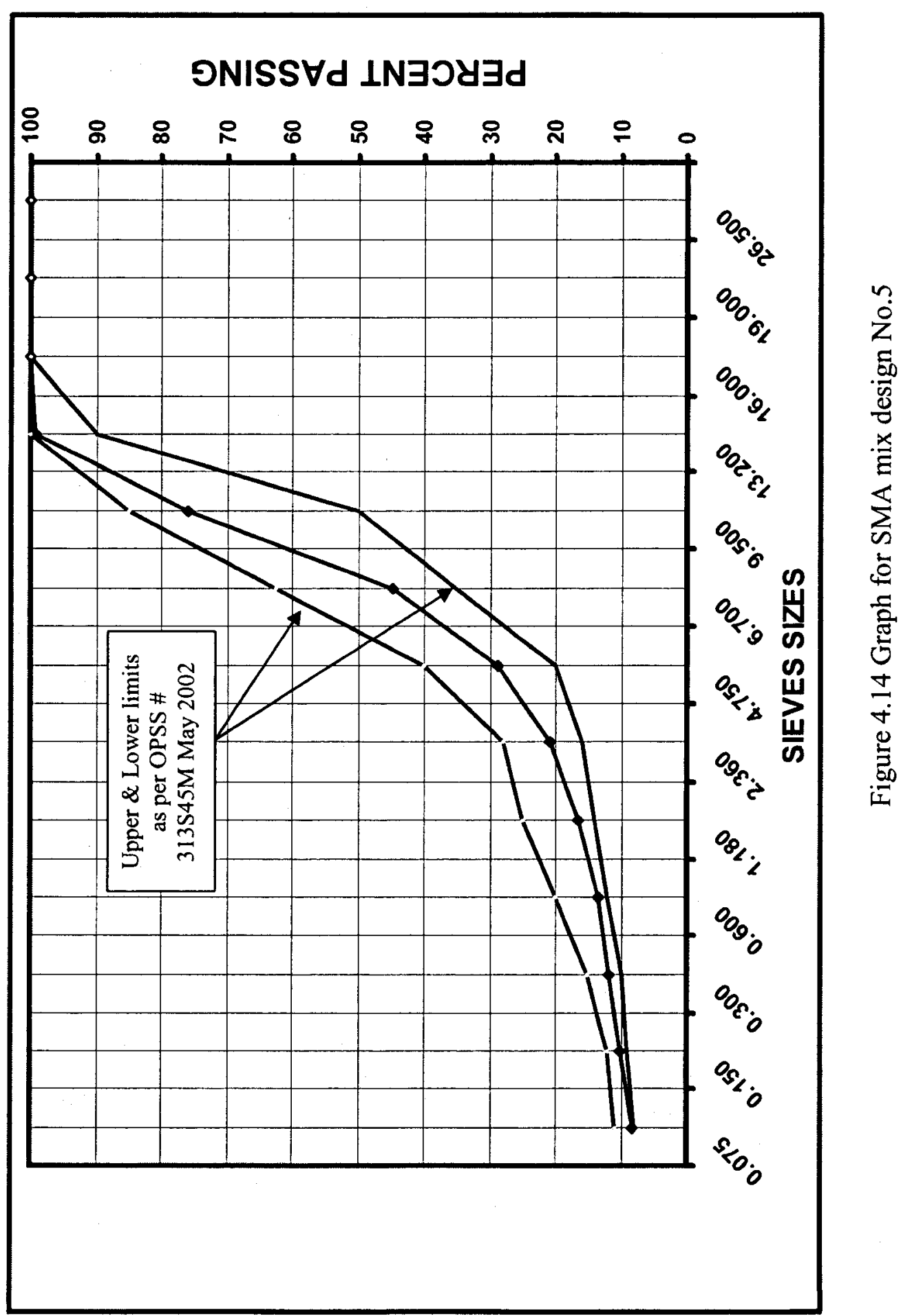


Figure 4.15 Property Curves for SMA mix design No.5

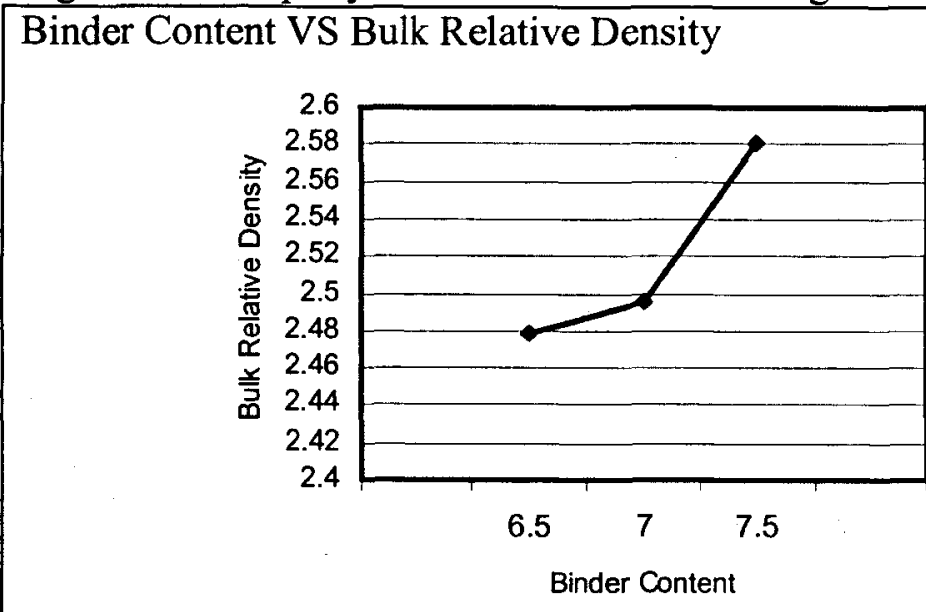

Binder Content VS \% Gmm @ N(design)

Binder Content VS Air Voids

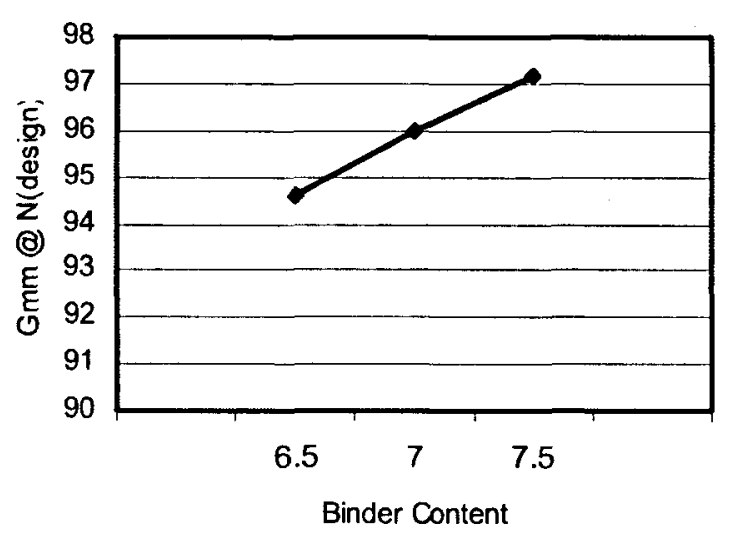

Binder Content VS VFA
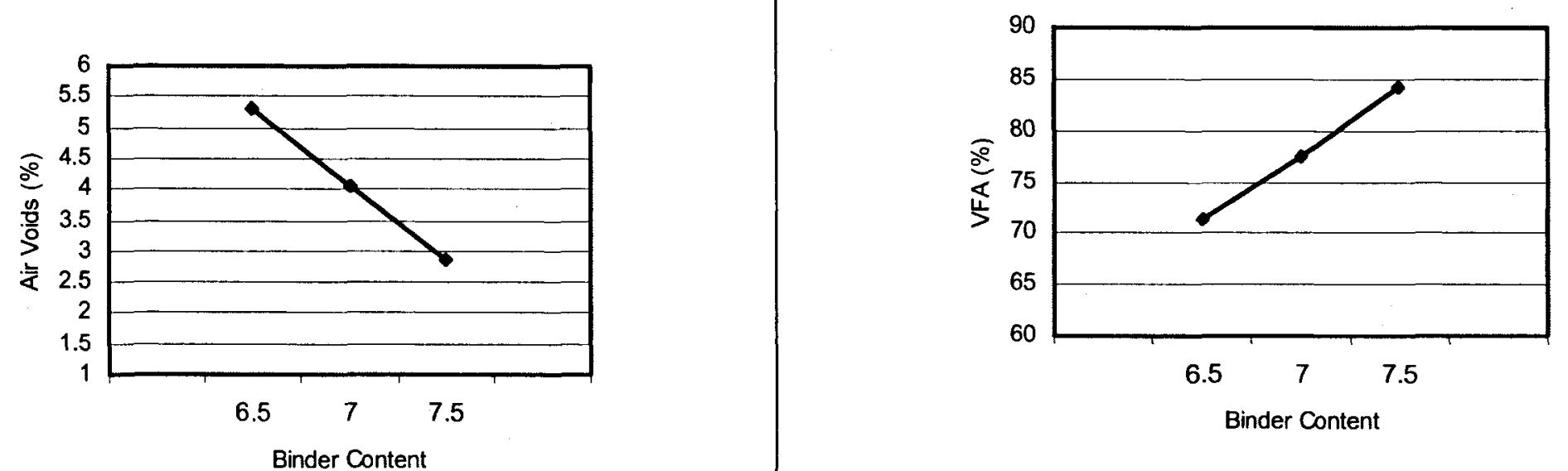
Table 4.20 Summary of Test Result

\begin{tabular}{|c|c|c|c|c|c|c|c|c|c|c|c|c|c|c|c|}
\hline $\begin{array}{l}\text { Mix } \\
\text { Design } \\
\text { No. }\end{array}$ & DESCRIPTION & $\begin{array}{l}\text { Binder } \\
\text { Content }\end{array}$ & $\begin{array}{c}\text { Binder } \\
\text { with } \\
\text { Shingles }\end{array}$ & $\begin{array}{c}\begin{array}{c}\text { Average } \\
\text { BRD }\end{array} \\
\text {. }\end{array}$ & $\begin{array}{l}\text { Average } \\
\text { MRD }\end{array}$ & $\begin{array}{l}\text { Required } \\
\text { Air } \\
\text { Voids }\end{array}$ & $\begin{array}{l}\text { Achieved } \\
\text { Air voids }\end{array}$ & $\begin{array}{l}\text { Required } \\
\text { VMA }\end{array}$ & $\begin{array}{l}\text { Achieved } \\
\text { VMA }\end{array}$ & $\begin{array}{c}\mathbf{G m m} \\
@ \\
\mathbf{N}_{\text {inittal }}\end{array}$ & $\begin{array}{c}\text { Gmm } \\
\text { @ } \\
N_{\text {design }}\end{array}$ & $\begin{array}{c}\text { Air } \\
\text { Voids } \\
@ \\
\text { Nosion }^{\text {@ }}\end{array}$ & $\overline{\text { VFA }}$ & $\overline{T S R R}$ & $\begin{array}{l}\text { Drain } \\
\text { down }\end{array}$ \\
\hline \multirow[t]{4}{*}{1} & \multirow{4}{*}{$\begin{array}{l}\text { SMA MIX WITH } \\
\text { 5\% SHINGLES }\end{array}$} & (\%) & $(\%)$ & $\mathrm{g} / \mathrm{cm}^{3}$ & $\mathrm{~g} / \mathrm{cm}^{3}$ & $(\%)$ & (\%) & $(\%)$ & (\%) & $(\%)$ & (\%) & (\%) & (\%) & (\%) & (\%) \\
\hline & & 3.5 & 5.0 & 2.483 & 2.641 & 4.00 & 5.98 & 17.00 & 17.25 & 83.00 & 94.00 & 6.00 & 65.22 & & \\
\hline & & 4.0 & 5.5 & 2.513 & 2.618 & 4.00 & 4.01 & 17.00 & 17.20 & 86.00 & 96.00 & 4.00 & 76.74 & 90.94 & 0.10 \\
\hline & & 4.5 & 6.0 & 2.513 & 2.600 & 4.00 & 3.35 & 17.00 & 17.64 & 88.40 & 97.80 & 2.20 & 87.53 & & \\
\hline$\overline{1 B}$ & $\begin{array}{l}\text { SMA MIX WITH 5\% } \\
\text { SHINGLES (DUST } \\
\text { REPLACED BY CKD) } \\
\end{array}$ & 4.0 & 5.5 & 2.514 & 2.614 & 4.00 & 3.83 & 17.00 & 17.80 & 85.92 & 96.35 & 3.65 & 79.49 & & \\
\hline \multirow[t]{3}{*}{2} & \multirow{3}{*}{$\begin{array}{l}\text { SMA MIX WITH } \\
\text { 3\% SHINGLES }\end{array}$} & 4.1 & 5.0 & 2.498 & 2.640 & 4.00 & 5.38 & 17.00 & 17.30 & 83.80 & 94.60 & 5.40 & 68.79 & & \\
\hline & & 4.6 & 5.5 & 2.518 & 2.622 & 4.00 & 3.97 & 17.00 & 17.00 & 86.00 & 96.00 & 4.00 & 76.47 & 84.65 & 0.00 \\
\hline & & 5.0 & 5.9 & 2.528 & 2.590 & 4.00 & 2.39 & 17.00 & 17.10 & 86.60 & 97.60 & 2.40 & 85.96 & & \\
\hline \multirow[t]{3}{*}{3} & \multirow[t]{3}{*}{$\begin{array}{l}\text { SMA MIX WITH } \\
\text { 0.6\% FIBERS }\end{array}$} & 5.5 & 5.5 & 2.496 & 2.642 & 4.00 & 5.53 & 17.00 & 17.70 & 83.50 & 94.50 & 5.50 & 68.93 & & \\
\hline & & 6.0 & 6.0 & 2.512 & 2.618 & 4.00 & 4.05 & 17.00 & 17.70 & 86.00 & 96.00 & 4.00 & 77.40 & 86.19 & 0.00 \\
\hline & & 6.5 & 6.5 & 2.520 & 2.599 & 4.00 & 3.04 & 17.00 & 17.90 & 86.50 & 97.00 & 3.00 & 83.24 & & \\
\hline \multirow[t]{3}{*}{$\overline{4}$} & \multirow{3}{*}{$\begin{array}{l}\text { SMA MIX WITH } \\
\text { 0.3\% FIBRES }\end{array}$} & 5.2 & 5.2 & 2.482 & 2.640 & 4.00 & 5.98 & 17.00 & 18.00 & 84.50 & 94.00 & 6.00 & 86.67 & & \\
\hline & & 5.7 & 5.7 & 2.513 & 2.617 & 4.00 & 3.97 & 17.00 & 17.40 & 86.00 & 96.00 & 4.00 & 77.01 & 82.10 & 0.00 \\
\hline & & 6.2 & 6.2 & 2.514 & 2.599 & 4.00 & 3.27 & 17.00 & 17.80 & 86.90 & 96.70 & 3.30 & 81.46 & & \\
\hline \multirow[t]{3}{*}{5} & \multirow{3}{*}{$\begin{array}{l}\text { SMA MIX WITH } \\
\text { 10\% SHINGLES } \\
\text { AND CKD }\end{array}$} & 3.5 & 6.5 & 2.478 & 2.618 & 4.00 & 5.35 & 17.00 & 18.86 & 85.00 & 94.60 & 5.40 & 71.37 & & \\
\hline & & 4.0 & 7.0 & 2.495 & 2.600 & 4.00 & 4.04 & 17.00 & 17.80 & 86.11 & 95.97 & 4.03 & 77.36 & 66.60 & 0.00 \\
\hline & & 4.5 & 7.5 & 2.506 & 2.580 & 4.00 & 2.87 & 17.00 & 17.94 & 86.76 & 97.15 & 2.85 & 84.11 & & \\
\hline
\end{tabular}




\subsection{Details of Tensile Strength}

The absolute tensile strength values with respect to each SMA Mix design are given in Table 4.21

Table 4.21 Details of Tensile strength

\begin{tabular}{|c|c|c|c|}
\hline Mix design Number & $\begin{array}{c}\text { Average } \\
\text { Tensile } \\
\text { Strength } \\
\text { (Dry) } \\
\text { (lbs) }\end{array}$ & $\begin{array}{c}\text { Average } \\
\text { Tensile } \\
\text { Strength } \\
\text { (Conditioned) } \\
\text { (lbs) }\end{array}$ & $\begin{array}{c}\text { Tensile } \\
\text { Strength } \\
\text { Ratio }\end{array}$ \\
\hline SMA Mix Design No.1 & 1396.7 & 1270.4 & 90.9 \\
\hline SMA Mix Design No.2 & 558.6 & 472.7 & 84.7 \\
\hline SMA Mix Design No.3 & 602.1 & 518.7 & 86.2 \\
\hline SMA Mix Design No.4 & 491.9 & 401.5 & 82.1 \\
\hline SMA Mix Design No.5 & 1131.5 & 753.3 & 66.6 \\
\hline
\end{tabular}

\subsection{Discussion of Results}

With respect to properties, all volumetric properties were within the required limits but the value of tensile strength is relatively high so that it could be a problem in future in terms of fatigue resistant or low temperature cracking in heavy traffic volume.

If we compare the results of both mixes with shingles and mixes with fibers, it is very clear that mixes with fibers will be more costly due to high binder content and in the mixes with shingles we are getting lot of economic and environmental benefits in terms of binder as well as recycling of scrap shingles. 


\section{Chapter 5 \\ Conclusions \& Recommendations}

\subsection{Conclusions}

1. The volumetric properties and tensile strength ratio were in compliance with Ontario Provincial Standard Specifications, with 5\% shingles. This would result in a saving of $2 \%$ of binder per ton of mixture which is a total cost of $\$ 4.0$ per ton of mix.

2. The $3 \%$ shingles did also meet the requirements of Ontario Provincial Standard Specifications; however it looks from tensile strength ratio that these mixes may be better in terms of fatigue. In other words, the mixture looks softer than that of containing $5 \%$ shingles.

3. Comparing the SMA mixes containing shingles with SMA containing fibers both can achieve the requirement of Ontario Provincial Standard Specifications, however the mixture with shingles have saving both in the cost of binder( about 1.1 to $2 \%$ saving) in addition to the cost of fibers

4. Cement kiln dust was found to require more binder content as compare to bag house dust, however this require further detailed investigation.

5. There are several economic advantages that can be realized by recycling prompt roofing shingle scrap for use in hot-mix asphalt. One of the most significant cost savings is incurred by diverting roofing shingle scrap from landfills.

6. In addition to saving landfill space, the benefits to recycling asphalt shingles in hot mix asphalt include possible economic savings and improved pavement performance. 


\subsection{Recommendations}

Based on the results obtained in this study the following are recommendations for further research in the area of recycling roof shingles in asphalt mixtures:

1. Performance testing should be conducting in SMA containing different levels of shingles to study the properties of such mixtures in terms of rutting, fatigue and low temperature cracking

2. It is recommended to test the binder extracted from shingles to get an idea about the properties of such binder and its effected performance. 


\section{References}

1. An overview of state of practice 1999 "Recycled Asphalt shingles in Road applications"

2. Anon. "The Ultimate Challenge - Stone Mastic Asphalt will be tested by Metro Toronto traffic and the Indy Machines", Asphalt topics, Vol.9, No.1, pp.5-9, 1995.

3. D. H. Little and J. A. Epps. "Evaluation of Certain Structural Characteristics of Recycled Pavement Materials" AAPT, Vol 49, 1980, pp 219-251

4. Dave Newcomb, and Dan Kirvit 1993 "Influence of roofing shingles on Asphalt mixtures"

5. "Designing and Constructing SMA Mixtures"-State-of-the-Practice,(1999) by National Asphalt Pavement Association

6. Donald E. Watson, Eyad Masad, Kathryn Ann Moore and Kevin Williams, 2004 "To determine stone-on-stone contact of HMA mixtures"

7. "Evaluation of the Benefits of Adding Waste Asphalt Roofing Shingles to Hot Mix Asphalt" Ohio State University, Transportation Technology Transfer Center.

8. Gerhard Kennepohl, Keith Davidson, John Emery, and Walter Schenik "Ontario experience with SMA and performance to date"

9. Hongbin Xie, Donald E. Watson 2004 “ Determining air void content in compacted SMA mixtures"

10. http://hotmix.ce.washington.edu/wsdot_web/Modules/05_mix_design/05-

6_body.htm

11. http://www.utexas.edu/research/superpave/articles/rap.html

12. "Influence of Roofing Shingles on Asphalt Concrete Mixture Properties", June 1993, University of Minnesota, Dept. of Civil and Mineral Engineering.

13. Janisch, David W. and Curtis M. Turgeon. "Minnesota's Experience with Scrap Shingles in Bituminous Pavements". Report No. MN/PR - 96/34, Minnesota Department of Transportation, 1996.

14. Kennepohi, G.J. and Davidson, J. K. (1992) "Introduction of Stone Mastic Asphalts (SMA) in Ontario" Journal of the Association of Asphalt Paving Technologists, Charleston, South Carolina, 61: 517-534. 
15. Mallick and Mogawen 2000 "Evaluation of use of asphalt shingles in HMA"

16. "Mechanistic Evaluation of Asphalt Concrete Mixtures Containing Reclaimed Roofing Materials" N. Ali, Dept. of Civil Engineering, Technical University of Nova Scotia, Canada, Transportation Research Record 1515.

17. Meyers, et al., "Study of Hot Mix Recycling of Asphalt Pavements" Roads and Transportation Association of Canada, Report \# TP 2964 E, 1983, Ottawa, Ontario.

18. Minnesota's Experience "Using Shingle Scrap in Bituminous Pavements" October 1996, Minn. DOT, David Janisch of Office of Minnesota Road Research and Curt Turgeon, Metropolitan Division.

19. Ontario Provincial Standard Specification Special Provision No.313S45M May 2002

20. Pedro Castro-Fernandez, Víctor Cervantes, Roy Barrantes and Vincent Blackamore (2003) "Effects of aging on asphalt concrete due to moisture damage"

21. Prithvi Kandhal, Shridhar Rao,Donald Watson and Brad Young "Performance of Recycled Mixtures in State of Georgia".FHWA Report No. FHWA-GA-94-9209, January 1994

22. Ratnasamy Muniandy, Ali A. Selim and Vernon R.Schaefer,.. " Effect of fibers in fatigue cracking of SMA mixtures"

23. Superpave Mix Design Method for Asphalt Concrete, MS-2, Asphalt Institute, Lexington, Kentucky.

24. Wiseblood, Nathan. Report on "Recycling Asphalt Shingles in Hot Mix" October 1993.

25. Woodman, C., Burlie, R. and Emery, J.J. (1996) "Stone Mastic Asphalt Technology for Urban pavements"

26. Yonkie, et al., 1999 " Evaluation of shingles modifier in asphalt mixes" 


\section{Appendix A \\ Volumetric Properties of Mix Designs}


Table A.1 Volumetric Properties for SMA mix Trial Blend A

\begin{tabular}{|c|c|c|c|}
\hline PARAMETER & $\begin{array}{c}\text { SPECIMEN } \\
1\end{array}$ & \begin{tabular}{|} 
SPECIMEN \\
2
\end{tabular} & AVERAGE \\
\hline Mass of Compacted specimen in Air & 4980.00 & 4950.00 & \\
\hline $\begin{array}{l}\text { S.D Mass of specimen in air after } \\
\text { immersion in water }\end{array}$ & 5005.30 & 5008.70 & \\
\hline $\begin{array}{l}\text { Mass of Compacted specimen in } \\
\text { Water }\end{array}$ & 3025.00 & 3055.00 & \\
\hline Volume & 1980.30 & 1953.70 & \\
\hline Bulk Relative Density & 2.515 & 2.534 & 2.524 \\
\hline Flask No. & 6 & 4 & \\
\hline Mass of Flask \& Mixture in Air & 2724.80 & 2683.70 & \\
\hline Mass of Flask in Air & 645.20 & 625.60 & \\
\hline Mass of Mixture in Air & 2079.60 & 2058.10 & \\
\hline Mass of Flask \& Mixture in Water & 1841.80 & 1813.50 & \\
\hline Mass of Flask in Water & 563.30 & 546.50 & \\
\hline Mass of Mixture in Water & 1278.50 & 1267.00 & \\
\hline Volume & 801.10 & 791.10 & \\
\hline Maximum Relative Density & 2.596 & 2.602 & 2.599 \\
\hline Average Air Voids (\%) & & & 2.87 \\
\hline Binder Content & 5.5 & & \\
\hline Volume of Aggregate + Binder & 0.97 & & \\
\hline Mass of Binder & 138.83 & & \\
\hline Mass of Aggregate & 2385.38 & & \\
\hline Volume of Aggregate & 0.84 & & \\
\hline VMA (\%) & \multicolumn{3}{|c|}{16.30} \\
\hline VFA (\%) & \multicolumn{3}{|c|}{82.86} \\
\hline
\end{tabular}




\begin{tabular}{|c|c|c|c|}
\hline PARAMETER & $\begin{array}{c}\text { SPECIMEN } \\
1\end{array}$ & $\begin{array}{c}\text { SPECIMEN } \\
2\end{array}$ & AVERAGE \\
\hline Mass of Compacted specimen in Air & 5000.50 & 4998.60 & \\
\hline $\begin{array}{l}\text { S.D Mass of specimen in air after } \\
\text { immersion in water }\end{array}$ & 5050.60 & 5046.50 & \\
\hline $\begin{array}{l}\text { Mass of Compacted specimen in } \\
\text { Water }\end{array}$ & 3080.50 & 3070.50 & \\
\hline Volume & 1970.10 & 1976.00 & \\
\hline Bulk Relative Density & 2.538 & 2.530 & 2.534 \\
\hline Flask No. & 6 & 4 & \\
\hline Mass of Flask \& Mixture in Air & 2630.50 & 2575.90 & \\
\hline Mass of Flask in Air & 620.10 & 650.10 & \\
\hline Mass of Mixture in Air & 2010.40 & 1925.80 & \\
\hline Mass of Flask \& Mixture in Water & 1784.60 & 1760.20 & \\
\hline Mass of Flask in Water & 541.80 & 567.80 & \\
\hline Mass of Mixture in Water & 1242.80 & 1192.40 & \\
\hline Volume & 767.60 & 733.40 & \\
\hline Maximum Relative Density & 2.619 & 2.626 & 2.622 \\
\hline Average Air Voids (\%) & & & 3.38 \\
\hline Binder Content & 5.5 & & \\
\hline Volume of Aggregate + Binder & 0.97 & & \\
\hline Mass of Binder & 139.37 & & \\
\hline Mass of Aggregate & 2394.56 & & \\
\hline Volume of Aggregate & 0.84 & & \\
\hline VMA (\%) & \multicolumn{3}{|c|}{15.98} \\
\hline VFA (\%) & \multicolumn{3}{|c|}{79.67} \\
\hline
\end{tabular}


Table A.3 Volumetric Properties for SMA mix Trial Blend C

\begin{tabular}{|c|c|c|c|}
\hline PARAMETER & $\begin{array}{c}\text { SPECIMEN } \\
1\end{array}$ & $\begin{array}{c}\text { SPECIMEN } \\
2\end{array}$ & AVERAGE \\
\hline Mass of Compacted specimen in Air & 5010.00 & 4998.90 & \\
\hline $\begin{array}{l}\text { S.D Mass of specimen in air after } \\
\text { immersion in water }\end{array}$ & 5015.00 & 5008.70 & \\
\hline Mass of Compacted specimen in Water & 3019.90 & 3020.80 & \\
\hline Volume & 1995.10 & 1987.90 & \\
\hline Bulk Relative Density & 2.511 & 2.515 & 2.513 \\
\hline Flask No. & 6 & 4 & \\
\hline Mass of Flask \& Mixture in Air & 2728.20 & 2728.20 & \\
\hline Mass of Flask in Air & 542.00 & 542.00 & \\
\hline Mass of Mixture in Air & 2186.20 & 2186.20 & \\
\hline Mass of Flask \& Mixture in Water & 1825.40 & 1822.60 & \\
\hline Mass of Flask in Water & 473.00 & 473.00 & \\
\hline Mass of Mixture in Water & 1352.40 & 1349.60 & \\
\hline Volume & 833.80 & 836.60 & \\
\hline Maximum Relative Density & 2.622 & 2.613 & 2.618 \\
\hline Average Air Voids (\%) & & & 4.00 \\
\hline Binder Content & 5.5 & & \\
\hline Volume of Aggregate+Binder & 0.96 & & \\
\hline Mass of Binder & 138.21 & & \\
\hline Mass of Aggregate & 2374.70 & & \\
\hline Volume of Aggregate & 0.83 & & \\
\hline VMA (\%) & \multicolumn{3}{|c|}{16.68} \\
\hline VFA (\%) & \multicolumn{3}{|c|}{76.68} \\
\hline
\end{tabular}


Table A.4 Volumetric Properties for SMA Mix design No.1

\begin{tabular}{|c|c|c|c|}
\hline \multicolumn{4}{|c|}{ SUPERPAVE BITUMINIOUS LABORATORY WORKSHEET } \\
\hline PARAMETER & SPECIMEN 1 & SPECIMEN 2 & AVERAGE \\
\hline $\begin{array}{l}\text { Mass of Compacted specimen } \\
\text { in Air }\end{array}$ & 5000.00 & 5010.00 & \\
\hline $\begin{array}{l}\text { S.D Mass of specimen in air } \\
\text { after immersion in water }\end{array}$ & 5020.00 & 5036.00 & \\
\hline $\begin{array}{l}\text { Mass of Compacted specimen } \\
\text { in Water }\end{array}$ & 3009.00 & 3015.00 & \\
\hline Volume & 2011.00 & 2021.00 & \\
\hline Bulk Relative Density & 2.486 & 2.479 & 2.483 \\
\hline Flask No. & 6 & 4 & \\
\hline Mass of Flask \& Mixture in Air & 2829.50 & 2695.80 & \\
\hline Mass of Flask in Air & 542.00 & 542.00 & \\
\hline Mass of Mixture in Air & 2287.50 & 2153.80 & \\
\hline $\begin{array}{l}\text { Mass of Flask \& Mixture in } \\
\text { Water }\end{array}$ & 1896.70 & 1809.00 & \\
\hline Mass of Flask in Water & 473.00 & 473.00 & \\
\hline Mass of Mixture in Water & 1423.70 & 1336.00 & \\
\hline Volume & 863.80 & 817.80 & \\
\hline Maximum Relative Density & 2.648 & 2.634 & 2.641 \\
\hline Average Air Voids (\%) & & & 5.99 \\
\hline Binder Content & 5 & & \\
\hline Volume of Aggregate + Binder & 0.94 & & \\
\hline Mass of Binder & 124.13 & & \\
\hline Mass of Aggregate & 2358.52 & & \\
\hline Volume of Aggregate & 0.82 & & \\
\hline VMA (\%) & & 17.25 & \\
\hline VFA (\%) & & 65.2 & \\
\hline
\end{tabular}


Table A.5 Volumetric Properties for SMA Mix design No.1

\begin{tabular}{|c|c|c|c|}
\hline \multicolumn{4}{|c|}{ SUPERPAVE BITUMINIOUS LABORATORY WORKSHEET } \\
\hline PARAMETER & SPECIMEN 1 & SPECIMEN 2 & AVERAGE \\
\hline $\begin{array}{l}\text { Mass of Compacted specimen } \\
\text { in Air }\end{array}$ & 5010.00 & 4998.90 & \\
\hline $\begin{array}{l}\text { S.D Mass of specimen in air } \\
\text { after immersion in water }\end{array}$ & 5015.00 & 5008.70 & \\
\hline $\begin{array}{l}\text { Mass of Compacted specimen } \\
\text { in Water }\end{array}$ & 3019.90 & 3020.80 & \\
\hline Volume & 1995.10 & 1987.90 & \\
\hline Bulk Relative Density & 2.511 & 2.515 & 2.513 \\
\hline Flask No. & 6 & 4 & \\
\hline Mass of Flask \& Mixture in Air & 2728.20 & 2728.20 & \\
\hline Mass of Flask in Air & 542.00 & 542.00 & \\
\hline Mass of Mixture in Air & 2186.20 & 2186.20 & \\
\hline $\begin{array}{l}\text { Mass of Flask \& Mixture in } \\
\text { Water }\end{array}$ & 1825.40 & 1822.60 & \\
\hline Mass of Flask in Water & 473.00 & 473.00 & \\
\hline Mass of Mixture in Water & 1352.40 & 1349.60 & \\
\hline Volume & 833.80 & 836.60 & \\
\hline Maximum Relative Density & 2.622 & 2.613 & 2.618 \\
\hline Average Air Voids (\%) & & & 4.00 \\
\hline Binder Content & 5.5 & & \\
\hline Volume of Aggregate+Binder & 0.96 & & \\
\hline Mass of Binder & 138.21 & & \\
\hline Mass of Aggregate & 2374.70 & & \\
\hline Volume of Aggregate & 0.83 & & \\
\hline VMA (\%) & & 17.20 & \\
\hline VFA (\%) & & 76.7 & \\
\hline
\end{tabular}


Table A.6 Volumetric Properties for SMA Mix design No.1

\begin{tabular}{|c|c|c|c|}
\hline \multicolumn{4}{|c|}{ SUPERPAVE BITUMINIOUS LABORATORY WORKSHEET } \\
\hline PARAMETER & SPECIMEN 1 & SPECIMEN 2 & AVERAGE \\
\hline $\begin{array}{l}\text { Mass of Compacted specimen } \\
\text { in Air }\end{array}$ & 4995.00 & 5018.00 & \\
\hline $\begin{array}{l}\text { S.D Mass of specimen in air } \\
\text { after immersion in water }\end{array}$ & 5025.90 & 5029.30 & \\
\hline $\begin{array}{l}\text { Mass of Compacted specimen } \\
\text { in Water }\end{array}$ & 3037.50 & 3033.00 & \\
\hline Volume & 1988.40 & 1996.30 & \\
\hline Bulk Relative Density & 2.512 & 2.514 & 2.513 \\
\hline Flask No. & 6 & 4 & \\
\hline Mass of Flask \& Mixture in Air & 2849.60 & 2593.70 & \\
\hline Mass of Flask in Air & 542.00 & 542.00 & \\
\hline Mass of Mixture in Air & 2307.60 & 2051.70 & \\
\hline $\begin{array}{l}\text { Mass of Flask \& Mixture in } \\
\text { Water }\end{array}$ & 1894.00 & 1735.00 & \\
\hline Mass of Flask in Water & 473.00 & 473.00 & \\
\hline Mass of Mixture in Water & 1421.00 & 1262.00 & \\
\hline Volume & 886.60 & 789.70 & \\
\hline Maximum Relative Density & 2.603 & 2.598 & 2.600 \\
\hline Average Air Voids (\%) & & & 3.37 \\
\hline Binder Content & 6 & & \\
\hline Volume of Aggregate+Binder & 0.97 & & \\
\hline Mass of Binder & 150.77 & & \\
\hline Mass of Aggregate & 2362.09 & & \\
\hline Volume of Aggregate & 0.82 & & \\
\hline VMA (\%) & & 17.64 & \\
\hline VFA (\%) & & 87.5 & \\
\hline
\end{tabular}


Table A.7 Properties of mixture through Marshall Method of SMA Mix design No.1

\begin{tabular}{|c|c|c|c|c|}
\hline \multicolumn{5}{|c|}{ BITUMINIOUS LABORATORY WORKSHEET } \\
\hline PARAMETER & \begin{tabular}{|c} 
SPECIMEN \\
1 \\
\end{tabular} & \begin{tabular}{|c|} 
SPECIMEN \\
2 \\
\end{tabular} & \begin{tabular}{|c|} 
SPECIMEN \\
3 \\
\end{tabular} & AVERAGE \\
\hline $\begin{array}{l}\text { Mass of Compacted } \\
\text { specimen in Air }\end{array}$ & 1245.20 & 1250.30 & 1243.50 & \\
\hline $\begin{array}{l}\text { S.D Mass of specimen in } \\
\text { air after immersion in } \\
\text { water }\end{array}$ & 1247.50 & 1251.60 & 1246.00 & \\
\hline $\begin{array}{l}\text { Mass of Compacted } \\
\text { specimen in Water }\end{array}$ & 752.00 & 755.60 & 750.80 & \\
\hline Volume & 495.50 & 496.00 & 495.20 & \\
\hline Bulk Relative Density & 2.513 & 2.521 & 2.511 & 2.515 \\
\hline Flask No. & 1 & 3 & & \\
\hline $\begin{array}{l}\text { Mass of Flask \& Mixture } \\
\text { in Air }\end{array}$ & 2525.90 & 2795.70 & & \\
\hline Mass of Flask in Air & 645.20 & 650.70 & & \\
\hline Mass of Mixture in Air & 1880.70 & 2145.00 & & \\
\hline $\begin{array}{l}\text { Mass of Flask \& Mixture } \\
\text { in Water }\end{array}$ & 1725.50 & 1896.50 & & \\
\hline Mass of Flask in Water & 563.30 & 568.40 & & \\
\hline $\begin{array}{l}\text { Mass of Mixture in } \\
\text { Water }\end{array}$ & 1162.20 & 1328.10 & & \\
\hline Volume & 718.50 & 816.90 & & \\
\hline $\begin{array}{l}\text { Maximum Relative } \\
\text { Density }\end{array}$ & 2.618 & 2.626 & 2.622 & \\
\hline Average Air Voids (\%) & & & 4.07 & \\
\hline Binder Content & 5.5 & & & \\
\hline $\begin{array}{l}\text { Volume of } \\
\text { Aggregate+Binder }\end{array}$ & 0.96 & & & \\
\hline Mass of Binder & 138.11 & & & \\
\hline Mass of Aggregate & 2373.00 & & & \\
\hline Volume of Aggregate & 0.83 & & & \\
\hline VMA (\%) & & 17.26 & & \\
\hline VFA (\%) & & 76.4 & & \\
\hline Stability (N) & 14750 & 14500 & 14000 & \\
\hline Average Stability(N) & & 14416.67 & & \\
\hline Flow $(\mathrm{mm})$ & 8.5 & 10 & 9.5 & \\
\hline Average Flow $(\mathrm{mm})$ & & 9.33 & & \\
\hline
\end{tabular}


Table A.8 Volumetric Properties of SMA mix design No.1B with CKD

\begin{tabular}{|c|c|c|c|}
\hline \multicolumn{4}{|c|}{ SUPERPAVE BITUMINIOUS LABORATORY WORKSHEET } \\
\hline PARAMETER & SPECIMEN 1 & SPECIMEN 2 & AVERAGE \\
\hline $\begin{array}{l}\text { Mass of Compacted specimen } \\
\text { in Air }\end{array}$ & 5010.50 & 5005.20 & \\
\hline $\begin{array}{l}\text { S.D Mass of specimen in air } \\
\text { after immersion in water }\end{array}$ & 5025.60 & 5020.90 & \\
\hline $\begin{array}{l}\text { Mass of Compacted specimen } \\
\text { in Water }\end{array}$ & 3035.00 & 3027.10 & \\
\hline Volume & 1990.60 & 1993.80 & \\
\hline Bulk Relative Density & 2.517 & 2.510 & 2.514 \\
\hline Flask No. & 6 & 4 & \\
\hline Mass of Flask \& Mixture in Air & 2652.60 & 2740.50 & \\
\hline Mass of Flask in Air & 625.60 & 610.10 & \\
\hline Mass of Mixture in Air & 2027.00 & 2130.40 & \\
\hline $\begin{array}{l}\text { Mass of Flask \& Mixture in } \\
\text { Water }\end{array}$ & 1800.00 & 1852.70 & \\
\hline Mass of Flask in Water & 546.50 & 533.10 & \\
\hline Mass of Mixture in Water & 1253.50 & 1319.60 & \\
\hline Volume & 773.50 & 810.80 & \\
\hline Maximum Relative Density & 2.621 & 2.628 & 2.624 \\
\hline Average Air Voids (\%) & & & 4.20 \\
\hline Binder Content & 5.5 & & \\
\hline Volume of Aggregate + Binder & 0.96 & & \\
\hline Mass of Binder & 138.26 & & \\
\hline Mass of Aggregate & 2375.48 & & \\
\hline Volume of Aggregate & 0.83 & & \\
\hline VMA (\%) & & 17.17 & \\
\hline VFA (\%) & & 79.5 & \\
\hline
\end{tabular}


Table A.9 Volumetric Properties of SMA mix Design No. 2

\begin{tabular}{|c|c|c|c|}
\hline \multicolumn{4}{|c|}{ SUPERPAVE BITUMINIOUS LABORATORY WORKSHEET } \\
\hline PARAMETER & SPECIMEN 1 & SPECIMEN 2 & AVERAGE \\
\hline $\begin{array}{l}\text { Mass of Compacted specimen } \\
\text { in Air }\end{array}$ & 4998.90 & 5002.30 & \\
\hline $\begin{array}{l}\text { S.D Mass of specimen in air } \\
\text { after immersion in water }\end{array}$ & 5015.20 & 5017.30 & \\
\hline $\begin{array}{l}\text { Mass of Compacted specimen } \\
\text { in Water }\end{array}$ & 3016.50 & 3012.30 & \\
\hline Volume & 1998.70 & 2005.00 & \\
\hline Bulk Relative Density & 2.501 & 2.495 & 2.498 \\
\hline Flask No. & 1 & 2 & \\
\hline Mass of Flask \& Mixture in Air & 2612.60 & 2684.60 & \\
\hline Mass of Flask in Air & 688.20 & 541.90 & \\
\hline Mass of Mixture in Air & 1924.40 & 2142.70 & \\
\hline $\begin{array}{l}\text { Mass of Flask \& Mixture in } \\
\text { Water }\end{array}$ & 1799.20 & 1802.00 & \\
\hline Mass of Flask in Water & 601.80 & 473.00 & \\
\hline Mass of Mixture in Water & 1197.40 & 1329.00 & \\
\hline Volume & 727.00 & 813.70 & \\
\hline Maximum Relative Density & 2.647 & 2.633 & 2.640 \\
\hline Average Air Voids (\%) & & & 5.38 \\
\hline Binder Content & 5 & & \\
\hline Volume of Aggregate+Binder & 0.95 & & \\
\hline Mass of Binder & 124.90 & & \\
\hline Mass of Aggregate & 2373.09 & & \\
\hline Volume of Aggregate & 0.83 & & \\
\hline VMA (\%) & & 17.26 & \\
\hline VFA (\%) & & 68.8 & \\
\hline
\end{tabular}


Table A.10 Volumetric Properties of SMA mix Design No. 2

\begin{tabular}{|c|c|c|c|}
\hline \multicolumn{4}{|c|}{ SUPERPAVE BITUMINIOUS LABORATORY WORKSHEET } \\
\hline PARAMETER & SPECIMEN 1 & SPECIMEN 2 & AVERAGE \\
\hline $\begin{array}{l}\text { Mass of Compacted specimen } \\
\text { in Air }\end{array}$ & 4995.50 & 4996.80 & \\
\hline $\begin{array}{l}\text { S.D Mass of specimen in air } \\
\text { after immersion in water }\end{array}$ & 5021.00 & 5012.60 & \\
\hline $\begin{array}{l}\text { Mass of Compacted specimen } \\
\text { in Water }\end{array}$ & 3035.00 & 3030.50 & \\
\hline Volume & 1986.00 & 1982.10 & \\
\hline Bulk Relative Density & 2.515 & 2.521 & 2.518 \\
\hline Flask No. & 1 & 2 & \\
\hline Mass of Flask \& Mixture in Air & 2689.60 & 2677.60 & \\
\hline Mass of Flask in Air & 688.20 & 541.90 & \\
\hline Mass of Mixture in Air & 2001.40 & 2135.70 & \\
\hline $\begin{array}{l}\text { Mass of Flask \& Mixture in } \\
\text { Water }\end{array}$ & 1840.60 & 1793.20 & \\
\hline Mass of Flask in Water & 601.80 & 473.00 & \\
\hline Mass of Mixture in Water & 1238.80 & 1320.20 & \\
\hline Volume & 762.60 & 815.50 & \\
\hline Maximum Relative Density & 2.624 & 2.619 & 2.622 \\
\hline Average Air Voids (\%) & & & 3.95 \\
\hline Binder Content & 5.5 & & \\
\hline Volume of Aggregate + Binder & 0.96 & & \\
\hline Mass of Binder & 138.50 & & \\
\hline Mass of Aggregate & 2379.66 & & \\
\hline Volume of Aggregate & 0.83 & & \\
\hline VMA (\%) & & 17.04 & \\
\hline VFA (\%) & & 76.5 & \\
\hline
\end{tabular}


Table A.11 Volumetric Properties of SMA mix Design No.2

\begin{tabular}{|c|c|c|c|}
\hline \multicolumn{4}{|c|}{ SUPERPAVE BITUMINIOUS LABORATORY WORKSHEET } \\
\hline PARAMETER & SPECIMEN 1 & SPECIMEN 2 & AVERAGE \\
\hline $\begin{array}{l}\text { Mass of Compacted specimen } \\
\text { in Air }\end{array}$ & 5002.20 & 4980.60 & \\
\hline $\begin{array}{l}\text { S.D Mass of specimen in air } \\
\text { after immersion in water }\end{array}$ & 5030.20 & 5017.80 & \\
\hline $\begin{array}{l}\text { Mass of Compacted specimen } \\
\text { in Water }\end{array}$ & 3052.40 & 3046.60 & \\
\hline Volume & 1977.80 & 1971.20 & \\
\hline Bulk Relative Density & 2.529 & 2.527 & 2.528 \\
\hline Flask No. & 1 & 2 & \\
\hline Mass of Flask \& Mixture in Air & 2152.10 & 2149.50 & \\
\hline Mass of Flask in Air & 688.20 & 541.90 & \\
\hline Mass of Mixture in Air & 1463.90 & 1607.60 & \\
\hline $\begin{array}{l}\text { Mass of Flask \& Mixture in } \\
\text { Water }\end{array}$ & 1500.30 & 1460.00 & \\
\hline Mass of Flask in Water & 601.80 & 473.00 & \\
\hline Mass of Mixture in Water & 898.50 & 987.00 & \\
\hline Volume & 565.40 & 620.60 & \\
\hline Maximum Relative Density & 2.589 & 2.590 & 2.590 \\
\hline Average Air Voids (\%) & & & 2.39 \\
\hline Binder Content & 5.9 & & \\
\hline Volume of Aggregate + Binder & 0.98 & & \\
\hline Mass of Binder & 149.15 & & \\
\hline Mass of Aggregate & 2378.78 & & \\
\hline Volume of Aggregate & 0.83 & & \\
\hline VMA (\%) & & 17.06 & \\
\hline VFA (\%) & & 86.0 & \\
\hline
\end{tabular}


Table A.12 Volumetric properties of SMA Mix design No.3

\begin{tabular}{||l|c|c|c|}
\hline \multicolumn{4}{|c|}{ SUPERPAVE BITUMINIOUS LABORATORY WORKSHEET } \\
\hline $\begin{array}{l}\text { Mass of Compacted specimen } \\
\text { in Air }\end{array}$ & 5055.00 & 5002.00 & \\
\hline $\begin{array}{l}\text { S.D Mass of specimen in air } \\
\text { after immersion in water }\end{array}$ & 5090.00 & 5055.30 & \\
\hline $\begin{array}{l}\text { Mass of Compacted specimen } \\
\text { in Water }\end{array}$ & 3065.60 & 3051.20 & \\
\hline Volume & 2024.40 & 2004.10 & \\
\hline Bulk Relative Density & 2.497 & 2.496 & 2.496 \\
\hline Flask No. & 1 & 2 & \\
\hline Mass of Flask \& Mixture in Air & 2719.50 & 2655.80 & \\
\hline Mass of Flask in Air & 688.20 & 541.90 & \\
\hline Mass of Mixture in Air & 2031.30 & 2113.90 & \\
\hline $\begin{array}{l}\text { Mass of Flask \& Mixture in } \\
\text { Water }\end{array}$ & 1865.60 & 1785.60 & \\
\hline Mass of Flask in Water & 601.80 & 473.00 & \\
\hline Mass of Mixture in Water & 1263.80 & 1312.60 & \\
\hline Volume & 767.50 & 801.30 & \\
\hline Maximum Relative Density & 2.647 & 2.638 & 2.642 \\
\hline Average Air Voids (\%) & & & 5.52 \\
\hline Binder Content & 5.5 & & \\
\hline Volume of Aggregate+Binder & 0.94 & & \\
\hline Mass of Binder & 137.31 & & \\
\hline Mass of Aggregate & 2359.15 & & \\
\hline Volume of Aggregate & 0.82 & & \\
\hline VMA (\%) & & 17.74 & \\
\hline VFA (\%) & & 68.9 & \\
\hline \hline
\end{tabular}


Table A.13 Volumetric properties of SMA Mix design No.3

\begin{tabular}{|c|c|c|c|}
\hline \multicolumn{4}{|c|}{ SUPERPAVE BITUMINIOUS LABORATORY WORKSHEET } \\
\hline PARAMETER & SPECIMEN 1 & SPECIMEN 2 & AVERAGE \\
\hline $\begin{array}{l}\text { Mass of Compacted specimen } \\
\text { in Air }\end{array}$ & 5078.60 & 5059.00 & \\
\hline $\begin{array}{l}\text { S.D Mass of specimen in air } \\
\text { after immersion in water }\end{array}$ & 5094.80 & 5068.30 & \\
\hline $\begin{array}{l}\text { Mass of Compacted specimen } \\
\text { in Water }\end{array}$ & 3072.50 & 3055.40 & \\
\hline Volume & 2022.30 & 2012.90 & \\
\hline Bulk Relative Density & 2.511 & 2.513 & 2.512 \\
\hline Flask No. & 1 & 2 & \\
\hline Mass of Flask \& Mixture in Air & 2715.00 & 2547.40 & \\
\hline Mass of Flask in Air & 688.20 & 541.90 & \\
\hline Mass of Mixture in Air & 2026.80 & 2005.50 & \\
\hline $\begin{array}{l}\text { Mass of Flask \& Mixture in } \\
\text { Water }\end{array}$ & 1854.60 & 1712.00 & \\
\hline Mass of Flask in Water & 601.80 & 473.00 & \\
\hline Mass of Mixture in Water & 1252.80 & 1239.00 & \\
\hline Volume & 774.00 & 766.50 & \\
\hline Maximum Relative Density & 2.619 & 2.616 & 2.618 \\
\hline Average Air Voids (\%) & & & 4.02 \\
\hline Binder Content & 6 & & \\
\hline Volume of Aggregate+Binder & 0.96 & & \\
\hline Mass of Binder & 150.74 & & \\
\hline Mass of Aggregate & 2361.56 & & \\
\hline Volume of Aggregate & 0.82 & & \\
\hline VMA (\%) & & 17.66 & \\
\hline VFA (\%) & & 77.4 & \\
\hline
\end{tabular}


Table A.14 Volumetric properties of SMA Mix design No.3

\begin{tabular}{|c|c|c|c|}
\hline \multicolumn{4}{|c|}{ SUPERPAVE BITUMINIOUS LABORATORY WORKSHEET } \\
\hline PARAMETER & SPECIMEN 1 & SPECIMEN 2 & AVERAGE \\
\hline $\begin{array}{l}\text { Mass of Compacted specimen } \\
\text { in Air }\end{array}$ & 5055.60 & 5045.90 & \\
\hline $\begin{array}{l}\text { S.D Mass of specimen in air } \\
\text { after immersion in water }\end{array}$ & 5080.90 & 5075.60 & \\
\hline $\begin{array}{l}\text { Mass of Compacted specimen } \\
\text { in Water }\end{array}$ & 3073.00 & 3074.60 & \\
\hline Volume & 2007.90 & 2001.00 & \\
\hline Bulk Relative Density & 2.518 & 2.522 & 2.520 \\
\hline Flask No. & 1 & 2 & \\
\hline Màss of Flask \& Mixture in Air & 2698.80 & 2648.90 & \\
\hline Mass of Flask in Air & 688.20 & 541.90 & \\
\hline Mass of Mixture in Air & 2010.60 & 2107.00 & \\
\hline $\begin{array}{l}\text { Mass of Flask \& Mixture in } \\
\text { Water }\end{array}$ & 1839.10 & 1769.00 & \\
\hline Mass of Flask in Water & 601.80 & 473.00 & \\
\hline Mass of Mixture in Water & 1237.30 & 1296.00 & \\
\hline Volume & 773.30 & 811.00 & \\
\hline Maximum Relative Density & 2.600 & 2.598 & 2.599 \\
\hline Average Air Voids (\%) & & & 3.05 \\
\hline Binder Content & 6.5 & & \\
\hline Volume of Aggregate+Binder & 0.97 & & \\
\hline Mass of Binder & 163.79 & & \\
\hline Mass of Aggregate & 2355.99 & & \\
\hline Volume of Aggregate & 0.82 & & \\
\hline VMA (\%) & & 17.85 & \\
\hline VFA (\%) & & 82.92 & \\
\hline
\end{tabular}


Table A.15 Volumetric Properties of SMA Mix design No.4 (Control)

\begin{tabular}{|c|c|c|c|}
\hline \multicolumn{4}{|c|}{ SUPERPAVE BITUMINIOUS LABORATORY WORKSHEET } \\
\hline PARAMETER & SPECIMEN 1 & SPECIMEN 2 & AVERAGE \\
\hline Mass of Compacted specimen in Air & 5021.20 & 5020.00 & \\
\hline $\begin{array}{l}\text { S.D Mass of specimen in air after } \\
\text { immersion in water }\end{array}$ & 5048.10 & 5046.50 & \\
\hline $\begin{array}{l}\text { Mass of Compacted specimen in } \\
\text { Water }\end{array}$ & 3026.60 & 3022.10 & \\
\hline Volume & 2021.50 & 2024.40 & \\
\hline Bulk Relative Density & 2.484 & 2.480 & 2.482 \\
\hline Flask No. & 1 & 2 & \\
\hline Mass of Flask \& Mixture in Air & 2650.10 & 2689.70 & \\
\hline Mass of Flask in Air & 688.20 & 541.90 & \\
\hline Mass of Mixture in Air & 1961.90 & 2147.80 & \\
\hline Mass of Flask \& Mixture in Water & 1821.00 & 1806.80 & \\
\hline Mass of Flask in Water & 601.80 & 473.00 & \\
\hline Mass of Mixture in Water & 1219.20 & 1333.80 & \\
\hline Volume & 742.70 & 814.00 & \\
\hline Maximum Relative Density & 2.642 & 2.639 & 2.640 \\
\hline Average Air Voids (\%) & & & 5.99 \\
\hline Binder Content & 5.2 & & \\
\hline Volume of Aggregate+Binder & 0.94 & & \\
\hline Mass of Binder & 129.05 & & \\
\hline Mass of A ggregate & 2352.77 & & \\
\hline Volume of Aggregate & 0.82 & & \\
\hline VMA $(\%)$ & & 17.96 & \\
\hline VFA (\%) & & 86.7 & \\
\hline
\end{tabular}


Table A.16 Volumetric Properties of SMA Mix design No.4 (Control)

\begin{tabular}{|c|c|c|c|}
\hline \multicolumn{4}{|c|}{ SUPERPAVE BITUMINIOUS LABORATORY WORKSHEET } \\
\hline PARAMETER & SPECIMEN 1 & SPECIMEN 2 & AVERAGE \\
\hline Mass of Compacted specimen in Air & 4995.50 & 4996.80 & \\
\hline $\begin{array}{l}\text { S.D Mass of specimen in air after } \\
\text { immersion in water }\end{array}$ & 5005.30 & 5008.70 & \\
\hline Mass of Compacted specimen in Water & 3018.00 & 3020.50 & \\
\hline Volume & 1987.30 & 1988.20 & \\
\hline Bulk Relative Density & 2.514 & 2.513 & 2.513 \\
\hline Flask No. & 1 & 2 & \\
\hline Mass of Flask \& Mixture in Air & 2719.50 & 2610.90 & \\
\hline Mass of Flask in Air & 688.20 & 541.90 & \\
\hline Mass of Mixture in Air & 2031.30 & 2069.00 & \\
\hline Mass of Flask \& Mixture in Water & 1857.60 & 1750.80 & \\
\hline Mass of Flask in Water & 601.80 & 473.00 & \\
\hline Mass of Mixture in Water & 1255.80 & 1277.80 & \\
\hline Volume & 775.50 & 791.20 & \\
\hline Maximum Relative Density & 2.619 & 2.615 & 2.617 \\
\hline Average Air Voids (\%) & & & 3.96 \\
\hline Binder Content & 5.7 & & \\
\hline Volume of Aggregate + Binder & 0.96 & & \\
\hline Mass of Binder & 143.27 & & \\
\hline Mass of Aggregate & 2370.20 & & \\
\hline Volume of Aggregate & 0.83 & & \\
\hline VMA (\%) & & 17.36 & \\
\hline VFA (\%) & & 77.0 & \\
\hline
\end{tabular}


Table A.17 Volumetric Properties of SMA Mix design No.4 (Control)

\begin{tabular}{|c|c|c|c|}
\hline \multicolumn{4}{|c|}{ SUPERPAVE BITUMINIOUS LABORATORY WORKSHEET } \\
\hline PARAMETER & SPECIMEN 1 & SPECIMEN 2 & AVERAGE \\
\hline $\begin{array}{l}\text { Mass of Compacted specimen } \\
\text { in Air }\end{array}$ & 4991.50 & 4987.10 & \\
\hline $\begin{array}{l}\text { S.D Mass of specimen in air } \\
\text { after immersion in water }\end{array}$ & 4998.70 & 4994.80 & \\
\hline $\begin{array}{l}\text { Mass of Compacted specimen } \\
\text { in Water }\end{array}$ & 3013.00 & 3010.60 & \\
\hline Volume & 1985.70 & 1984.20 & \\
\hline Bulk Relative Density & 2.514 & 2.513 & 2.514 \\
\hline Flask No. & 1 & 2 & \\
\hline Mass of Flask \& Mixture in Air & 2597.80 & 2648.60 & \\
\hline Mass of Flask in Air & 688.20 & 541.90 & \\
\hline Mass of Mixture in Air & 1909.60 & 2106.70 & \\
\hline $\begin{array}{l}\text { Mass of Flask \& Mixture in } \\
\text { Water }\end{array}$ & 1774.60 & 1771.50 & \\
\hline Mass of Flask in Water & 601.80 & 473.00 & \\
\hline Mass of Mixture in Water & 1172.80 & 1298.50 & \\
\hline Volume & 736.80 & 808.20 & \\
\hline Maximum Relative Density & 2.592 & 2.607 & 2.599 \\
\hline Average Air Voids (\%) & & & 3.29 \\
\hline Binder Content & 6.2 & & \\
\hline Volume of Aggregate+Binder & 0.97 & & \\
\hline Mass of Binder & 155.84 & & \\
\hline Mass of Aggregate & 2357.72 & & \\
\hline Volume of Aggregate & 0.82 & & \\
\hline $\operatorname{VMA}(\%)$ & & 17.79 & \\
\hline VFA (\%) & & 81.5 & \\
\hline
\end{tabular}


Table A.18 Volumetric Properties of SMA mix design No.5

\begin{tabular}{|c|c|c|c|}
\hline \multicolumn{4}{|c|}{ SUPERPAVE BITUMINIOUS LABORATORY WORKSHEET } \\
\hline PARAMETER & SPECIMEN 1 & SPECIMEN 2 & AVERAGE \\
\hline Mass of Compacted specimen in Air & 5005.60 & 5010.70 & \\
\hline $\begin{array}{l}\text { S.D Mass of specimen in air after } \\
\text { immersion in water }\end{array}$ & 5035.60 & 5022.90 & \\
\hline Mass of Compacted specimen in Water & 3018.90 & 2998.00 & \\
\hline Volume & 2016.70 & 2024.90 & \\
\hline Bulk Relative Density & 2.482 & 2.475 & 2.478 \\
\hline Flask No. & 6 & 4 & \\
\hline Mass of Flask \& Mixture in Air & 2566.60 & 2649.70 & \\
\hline Mass of Flask in Air & 625.60 & 610.10 & \\
\hline Mass of Mixture in Air & 1941.00 & 2039.60 & \\
\hline Mass of Flask \& Mixture in Water & 1747.80 & 1791.60 & \\
\hline Mass of Flask in Water & 546.50 & 533.10 & \\
\hline Mass of Mixture in Water & 1201.30 & 1258.50 & \\
\hline Volume & 739.70 & 781.10 & \\
\hline Maximum Relative Density & 2.624 & 2.611 & 2.618 \\
\hline Air Voids & & & 5.32 \\
\hline Binder Content & 6.1 & & \\
\hline Volume of Aggregate+Binder & 0.95 & & \\
\hline Mass of Binder & 151.18 & & \\
\hline Mass of Aggregate & 2327.13 & & \\
\hline Volume of Aggregate & 0.81 & & \\
\hline VMA & & 18.86 & \\
\hline VFA & & 71.4 & \\
\hline
\end{tabular}


Table A.19 Volumetric Properties of SMA mix design No.5

\begin{tabular}{|l|c|c|c|}
\hline \multicolumn{3}{|c|}{ SUPERPAVE BITUMINIOUS LABORATORY WORKSHEET } \\
\hline $\begin{array}{l}\text { Pass of Compacted specimen } \\
\text { in Air }\end{array}$ & 4998.60 & 5010.60 & \\
\hline $\begin{array}{l}\text { S.D Mass of specimen in air } \\
\text { after immersion in water }\end{array}$ & 5017.90 & 5015.60 & \\
\hline $\begin{array}{l}\text { Mass of Compacted specimen } \\
\text { in Water }\end{array}$ & 3018.50 & 3003.60 & \\
\hline Volume & 1999.40 & 2012.00 & \\
\hline Bulk Relative Density & 2.500 & 2.490 & 2.495 \\
\hline Flask No. & 6 & 4 & \\
\hline Mass of Flask \& Mixture in Air & 2629.80 & 2689.70 & \\
\hline Mass of Flask in Air & 625.60 & 610.10 & \\
\hline Mass of Mixture in Air & 2004.20 & 2079.60 & \\
\hline Mass of Flask \& Mixture in & & & \\
Water & 1780.50 & 1812.00 & \\
\hline Mass of Flask in Water & 546.50 & 533.10 & \\
\hline Mass of Mixture in Water & 1234.00 & 1278.90 & \\
\hline Volume & 770.20 & 800.70 & \\
\hline Maximum Relative Density & 2.602 & 2.597 & 2.600 \\
\hline Average Air Voids (\%) & & & 4.02 \\
\hline Binder Content & 7 & & \\
\hline Volume of Aggregate+Binder & 0.96 & & \\
\hline Mass of Binder & 174.66 & & \\
\hline Mass of Aggregate & 2320.54 & & \\
\hline Volume of Aggregate & 0.81 & & \\
\hline VMA (\%) & & & \\
\hline VFA (\%) & & & \\
\hline
\end{tabular}


Table A.20 Volumetric Properties of SMA mix design No. 5

\begin{tabular}{|l|c|c|c|}
\hline \multicolumn{1}{|c|}{ PUPERPAVE BITUMINIOUS LABORATORY WORKSHEET } \\
\hline $\begin{array}{l}\text { Mass of Compacted specimen in } \\
\text { Air }\end{array}$ & SPECIMEN 1 & SPECIMEN 2 & AVERAGE \\
\hline $\begin{array}{l}\text { S.D Mass of specimen in air after } \\
\text { immersion in water }\end{array}$ & 5012.60 & 5010.90 & \\
\hline $\begin{array}{l}\text { Mass of Compacted specimen in } \\
\text { Water }\end{array}$ & 5024.60 & 5019.50 & \\
\hline Volume & 3025.00 & 3020.00 & \\
\hline Bulk Relative Density & 1999.60 & 1999.50 & \\
\hline Flask No. & 2.507 & 2.506 & 2.506 \\
\hline Mass of Flask \& Mixture in Air & 2548.70 & 2657.80 & \\
\hline Mass of Flask in Air & 625.60 & 610.10 & \\
\hline Mass of Mixture in Air & 1923.10 & 2047.70 & \\
\hline Mass of Flask \& Mixture in Water & 1725.40 & 1786.00 & \\
\hline Mass of Flask in Water & 546.50 & 533.10 & \\
\hline Mass of Mixture in Water & 1178.90 & 1252.90 & \\
\hline Volume & 744.20 & 794.80 & \\
\hline Maximum Relative Density & 2.584 & 2.576 & 2.580 \\
\hline Air Voids & & & 2.86 \\
\hline Binder Content & 6.1 & & \\
\hline Volume of Aggregate+Binder & 0.97 & & \\
\hline Mass of Binder & 152.89 & & \\
\hline Mass of Aggregate & 2353.55 & & \\
\hline Volume of Aggregate & 0.82 & & \\
\hline VMA & & & \\
\hline VFA & & & \\
\hline
\end{tabular}




\section{Appendix B}

Superpave Densification Data 
Table B.1 Superpave Data for SMA Mix trial Blend A

\begin{tabular}{||l|c|c|}
\hline \multicolumn{1}{|c|}{ PARAMETER } & SPECIMEN 1 & SPECIMEN 2 \\
\hline A1: MASS OF COMPACTED SPECIMEN IN AIR & 4980 & 4950 \\
\hline A2: S.D.MASS IN AIR AFTER IMMERSSION IN H2O & 5005.3 & 5008.7 \\
\hline B1: MASS OF COMPACTED SPECIMEN IN WATER & 3025 & 3055 \\
\hline B2: VOLUME (= A2-B1) & 1980.3 & 1953.7 \\
\hline C: BULK REL. DENSITY (=A1/B2), Gmb Measured & 2.515 & 2.534 \\
\hline D: MAX. THEORITICAL DENSITY, Gmm & & 2.599 \\
\hline
\end{tabular}

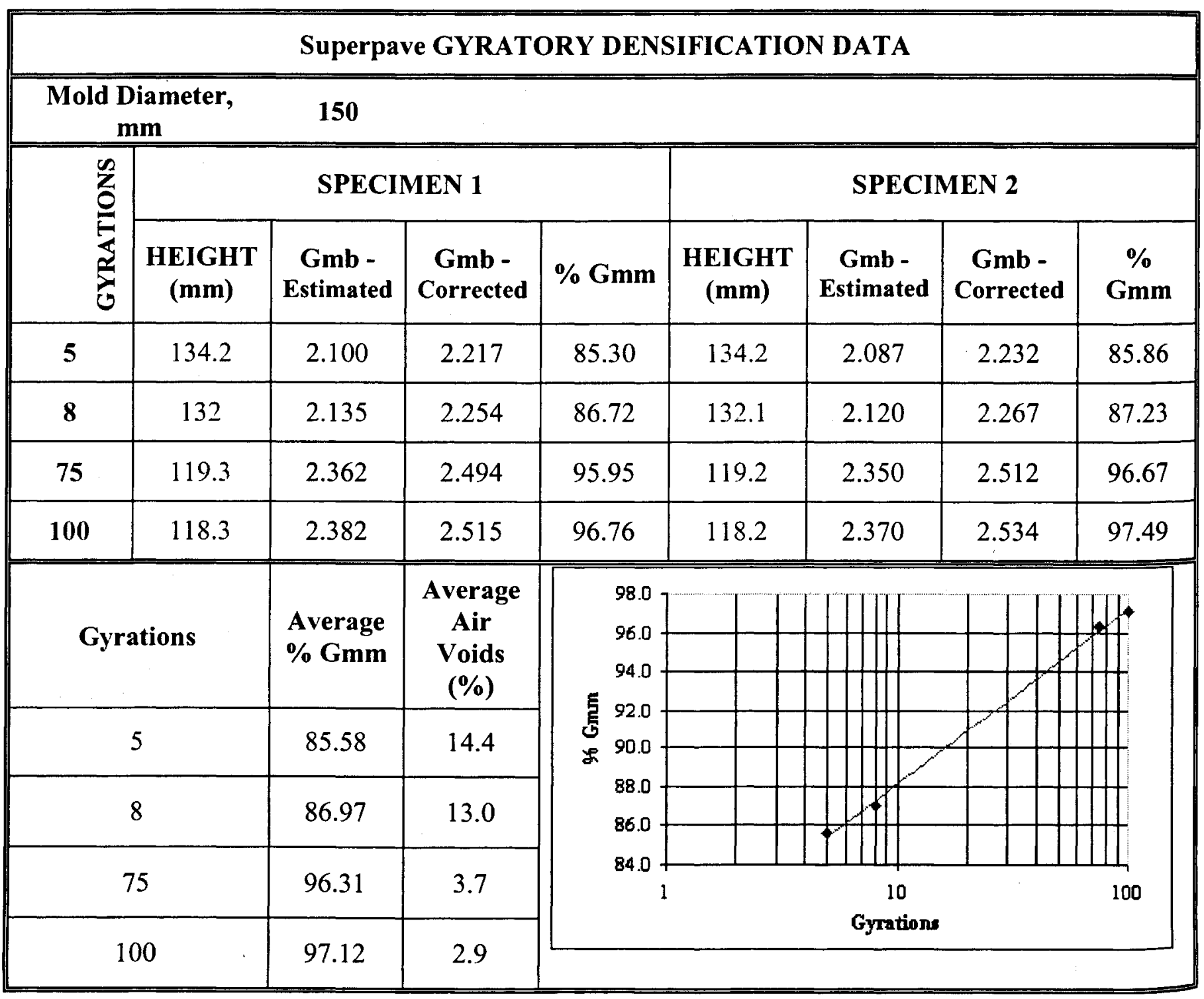


Table B.2 Superpave Data for SMA Mix Trial Blend B

\begin{tabular}{||l|c|c|}
\hline \multicolumn{1}{|c|}{ PARAMETER } & SPECIMEN 1 & SPECIMEN 2 \\
\hline A1: MASS OF COMPACTED SPECIMEN IN AIR & 5000.5 & 4998.6 \\
\hline A2: S.D.MASS IN AIR AFTER IMMERSSION IN H $2 \mathrm{O}$ & 5050.6 & 5046.5 \\
\hline B1: MASS OF COMPACTED SPECIMEN IN WATER & 3080.5 & 3070.5 \\
\hline B2: VOLUME (= A2-B1) & 1970.1 & 1976 \\
\hline C: BULK REL. DENSITY (= A1/B2), Gmb Measured & 2.538 & 2.530 \\
\hline D: MAX. THEORITICAL DENSITY, Gmm & & 2.622 \\
\hline
\end{tabular}

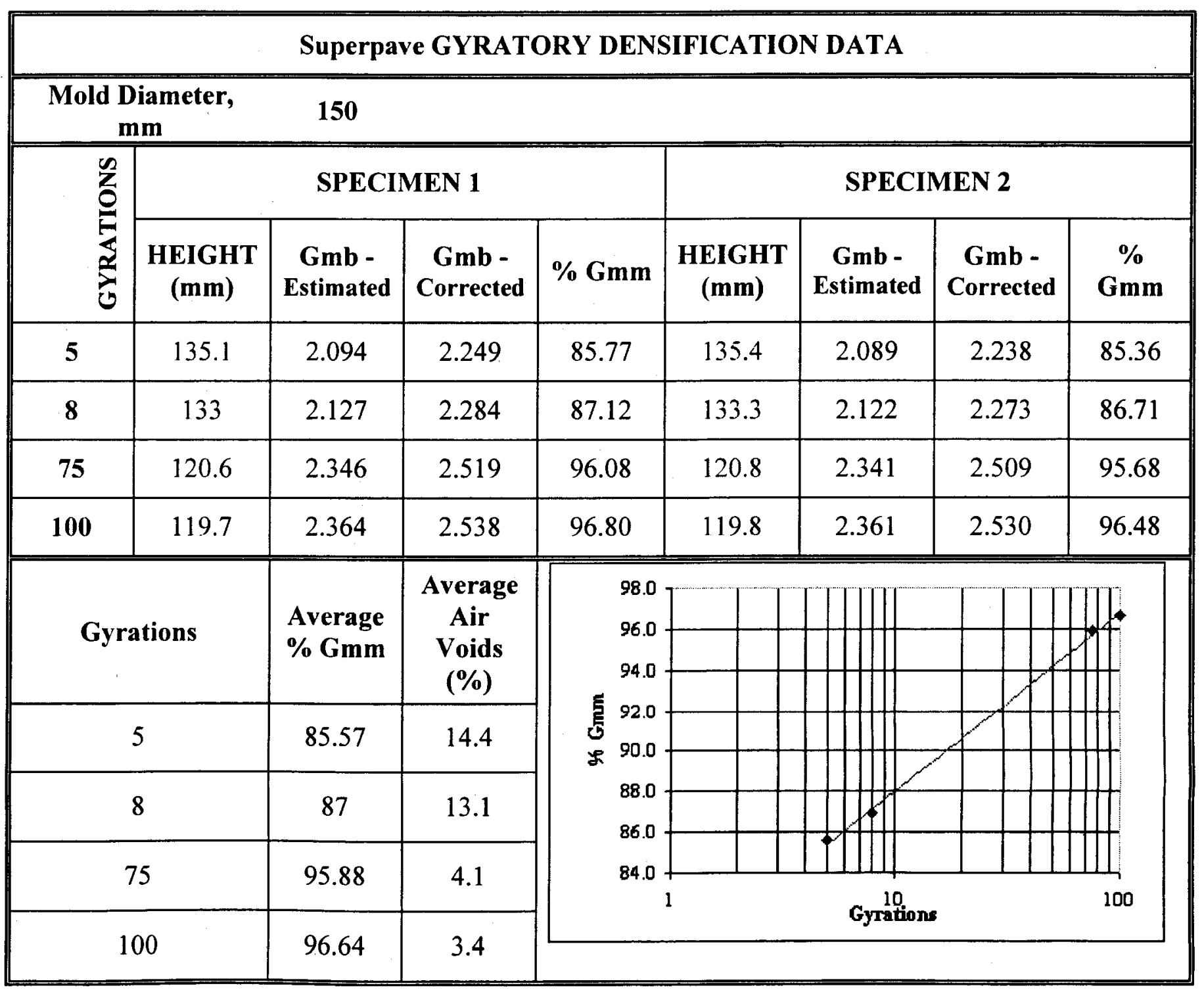


Table B.3 Superpave Data for SMA Mix trial Blend C

\begin{tabular}{|l|c|c|}
\hline \multicolumn{1}{|c|}{ PARAMETER } & SPECIMEN 1 & SPECIMEN 2 \\
\hline A1: MASS OF COMPACTED SPECIMEN IN AIR & 5010 & 4998.9 \\
\hline A2: S.D.MASS IN AIR AFTER IMMERSSION IN H $\mathrm{H}_{2} \mathrm{O}$ & 5015 & 5008.7 \\
\hline B1: MASS OF COMPACTED SPECIMEN IN WATER & 3019.9 & 3020.8 \\
\hline B2: VOLUME (= A2-B1) & 1995.1 & 1987.9 \\
\hline C: BULK REL. DENSITY (= A1/B2), Gmb Measured & 2.511 & 2.515 \\
\hline D: MAX. THEORITICAL DENSITY, Gmm & \multicolumn{2}{|c|}{2.618} \\
\hline
\end{tabular}

\begin{tabular}{|c|c|c|c|c|c|c|c|c||}
\hline \multicolumn{7}{|c|}{ Superpave GYRATORY DENSIFICATION DATA } \\
\hline $\begin{array}{c}\text { Mold Diameter, } \\
\text { mm }\end{array}$ \\
\hline \\
\hline
\end{tabular}


Table B.4 Superpave data for SMA mix design No.1

\begin{tabular}{|l|c|c}
\hline \multicolumn{1}{|c|}{ PARAMETER } & SPECIMEN 1 & SPECIMEN 2 \\
\hline A1: MASS OF COMPACTED SPECIMEN IN AIR & 5000 & 5010 \\
\hline A2: S.D.MASS IN AIR AFTER IMMERSSION IN H2O & 5020 & 5036 \\
\hline B1: MASS OF COMPACTED SPECIMEN IN WATER & 3009 & 3015 \\
\hline B2: VOLUME (= A2-B1) & 2011 & 2021 \\
\hline C: BULK REL. DENSITY $(=$ A1/B2), Gmb Measured & 2.486 & 2.479 \\
\hline D: MAX. THEORITICAL DENSITY, Gmm & \multicolumn{2}{|c}{2.641} \\
\hline
\end{tabular}

\section{Superpave GYRATORY DENSIFICATION DATA}

Mold Diameter, $\mathrm{mm} \quad 150$

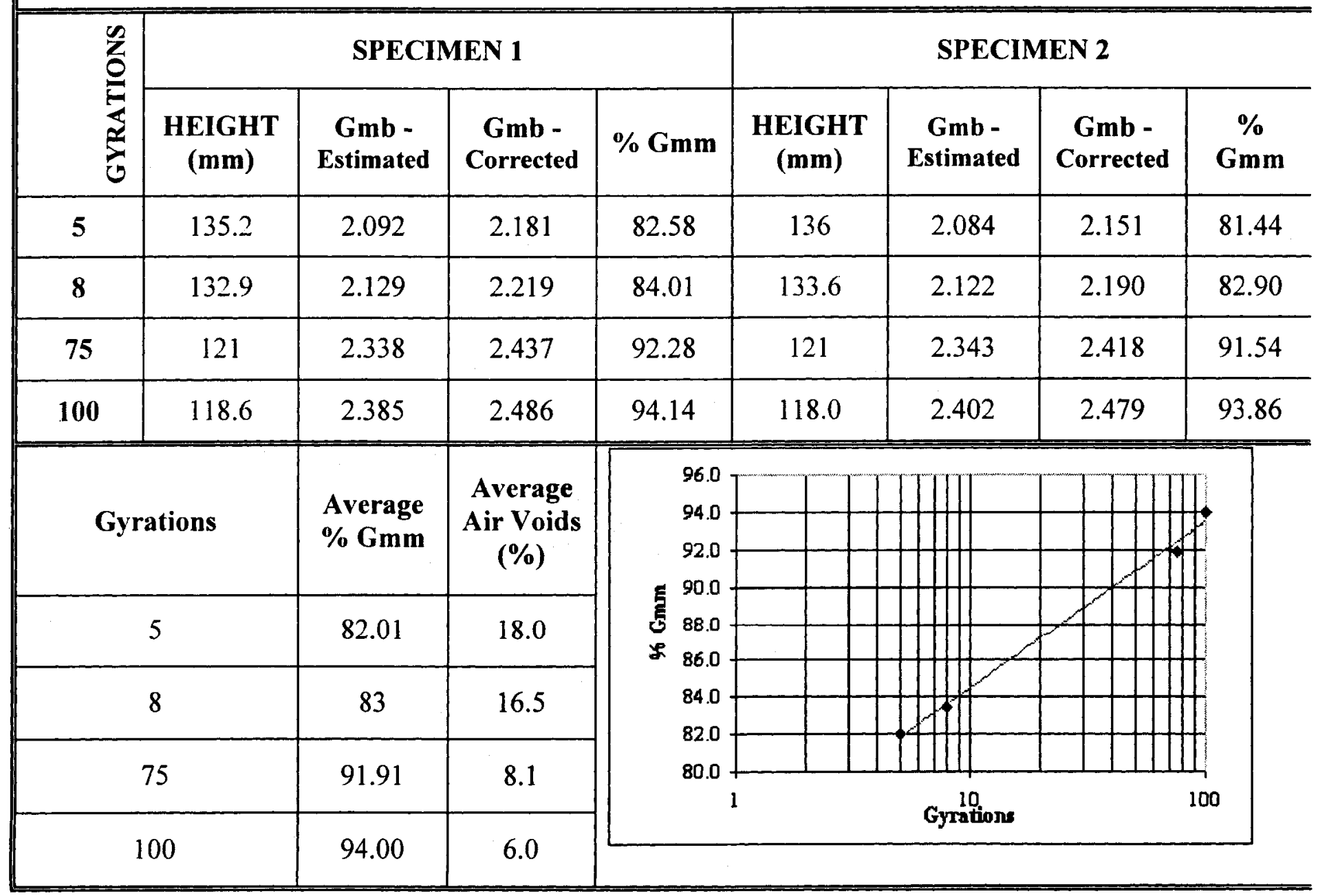


Table B.5 Superpave data for SMA mix design No.1

\begin{tabular}{|l|c|c|}
\hline \multicolumn{1}{|c|}{ PARAMETER } & SPECIMEN 1 & SPECIMEN 2 \\
\hline A1: MASS OF COMPACTED SPECIMEN IN AIR & 5010 & 4998.9 \\
\hline A2: S.D.MASS IN AIR AFTER IMMERSSION IN H2O & 5015 & 5008.7 \\
\hline B1: MASS OF COMPACTED SPECIMEN IN WATER & 3019.9 & 3020.8 \\
\hline B2: VOLUME (= A2-B1) & 1995.1 & 1987.9 \\
\hline C: BULK REL. DENSITY (= A1/B2), Gmb Measured & 2.511 & 2.515 \\
\hline D: MAX. THEORITICAL DENSITY, Gmm & \multicolumn{2}{|c|}{2.618} \\
\hline
\end{tabular}

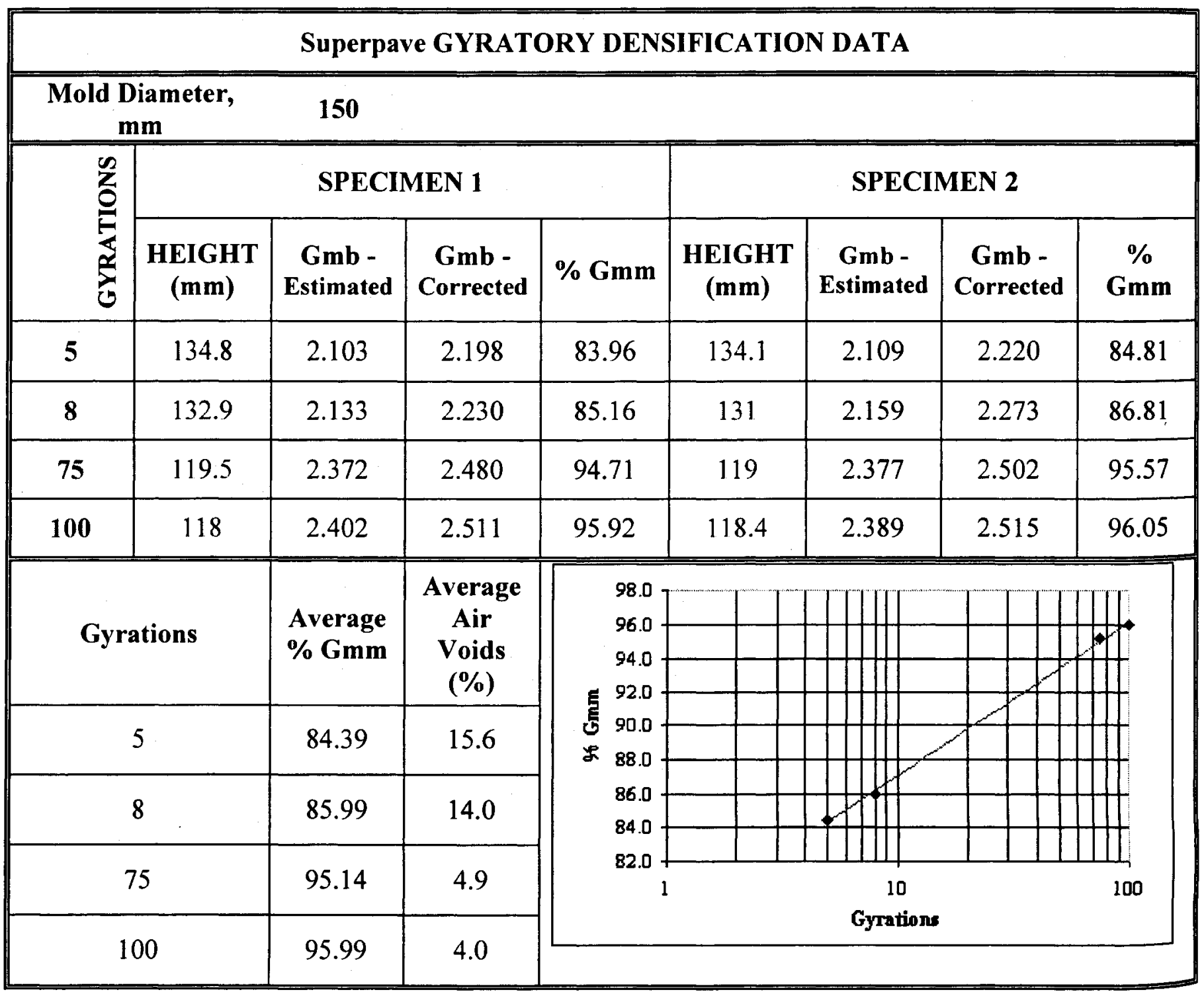


Table B.6 Superpave data for SMA mix design No.1

\begin{tabular}{||l|c|c|}
\hline \multicolumn{1}{|c|}{ PARAMETER } & SPECIMEN 1 & SPECIMEN 2 \\
\hline A1: MASS OF COMPACTED SPECIMEN IN AIR & 4995 & 5018 \\
\hline A2: S.D.MASS IN AIR AFTER IMMERSSION IN H2O & 5025.9 & 5029.3 \\
\hline B1: MASS OF COMPACTED SPECIMEN IN WATER & 3037.5 & 3033 \\
\hline B2: VOLUME (= A2-B1) & 1988.4 & 1996.3 \\
\hline C: BULK REL. DENSITY (= A1/B2), Gmb Measured & 2.512 & 2.514 \\
\hline D: MAX. THEORITICAL DENSITY, Gmm & \multicolumn{2}{|c|}{2.600} \\
\hline
\end{tabular}

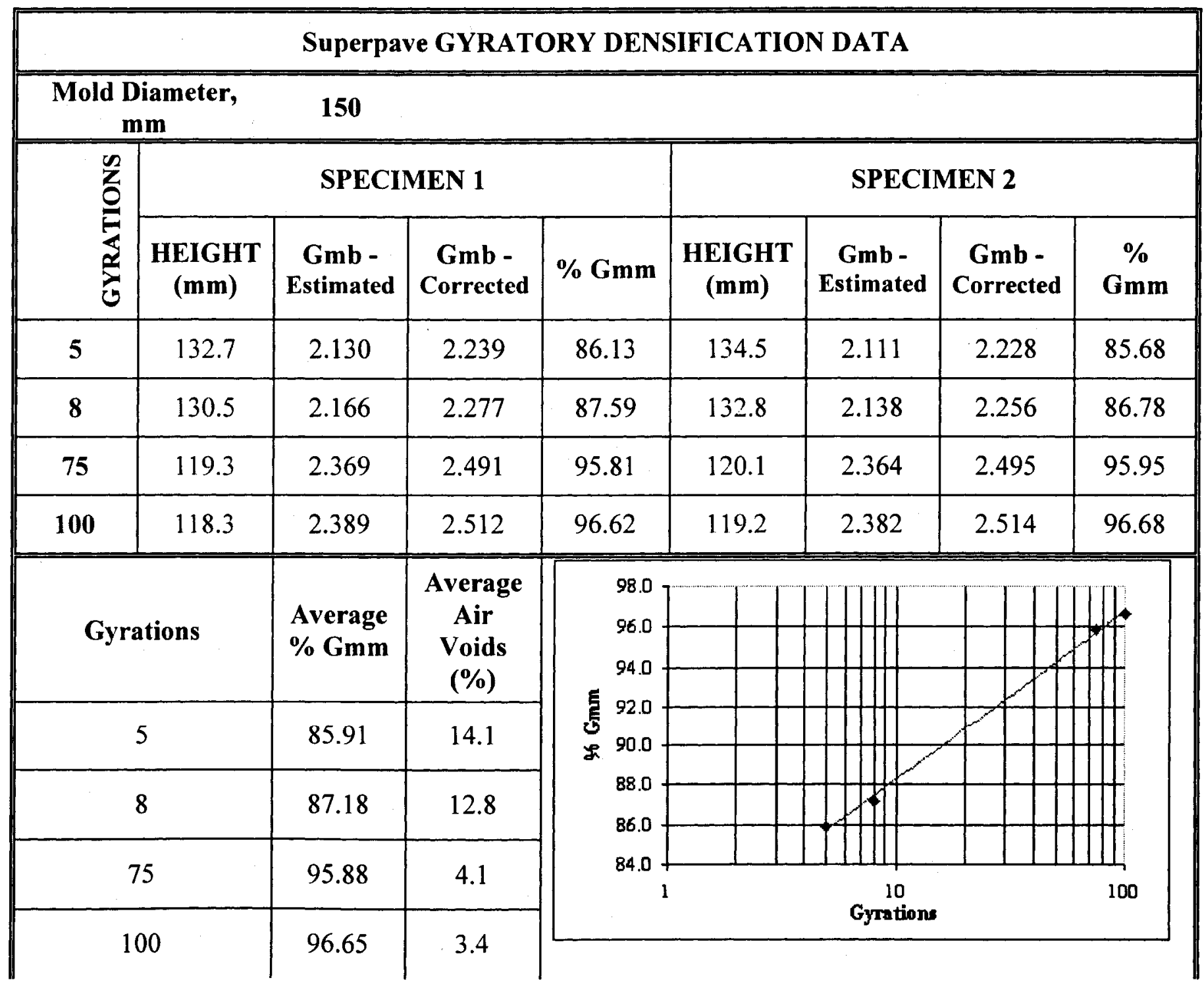


Table B. $7 \mathrm{~N}_{(\max )}$ Superpave data for SMA mix design No.1

\begin{tabular}{||l|c|c|}
\hline \multicolumn{1}{|c|}{ PARAMETER } & SPECIMEN 1 & SPECIMEN 2 \\
\hline A1: MASS OF COMPACTED SPECIMEN IN AIR & 5015.8 & 5018 \\
\hline A2: S.D.MASS IN AIR AFTER IMMERSSION IN H $2 \mathrm{O}$ & 5025.9 & 5029.3 \\
\hline B1: MASS OF COMPACTED SPECIMEN IN WATER & 3038.5 & 3039 \\
\hline B2: VOLUME (= A2-B1) & 1987.4 & 1990.3 \\
\hline C: BULK REL. DENSITY (= A1/B2), Gmb Measured & 2.524 & 2.521 \\
\hline D: MAX. THEORITICAL DENSITY, Gmm & & 2.621 \\
\hline
\end{tabular}

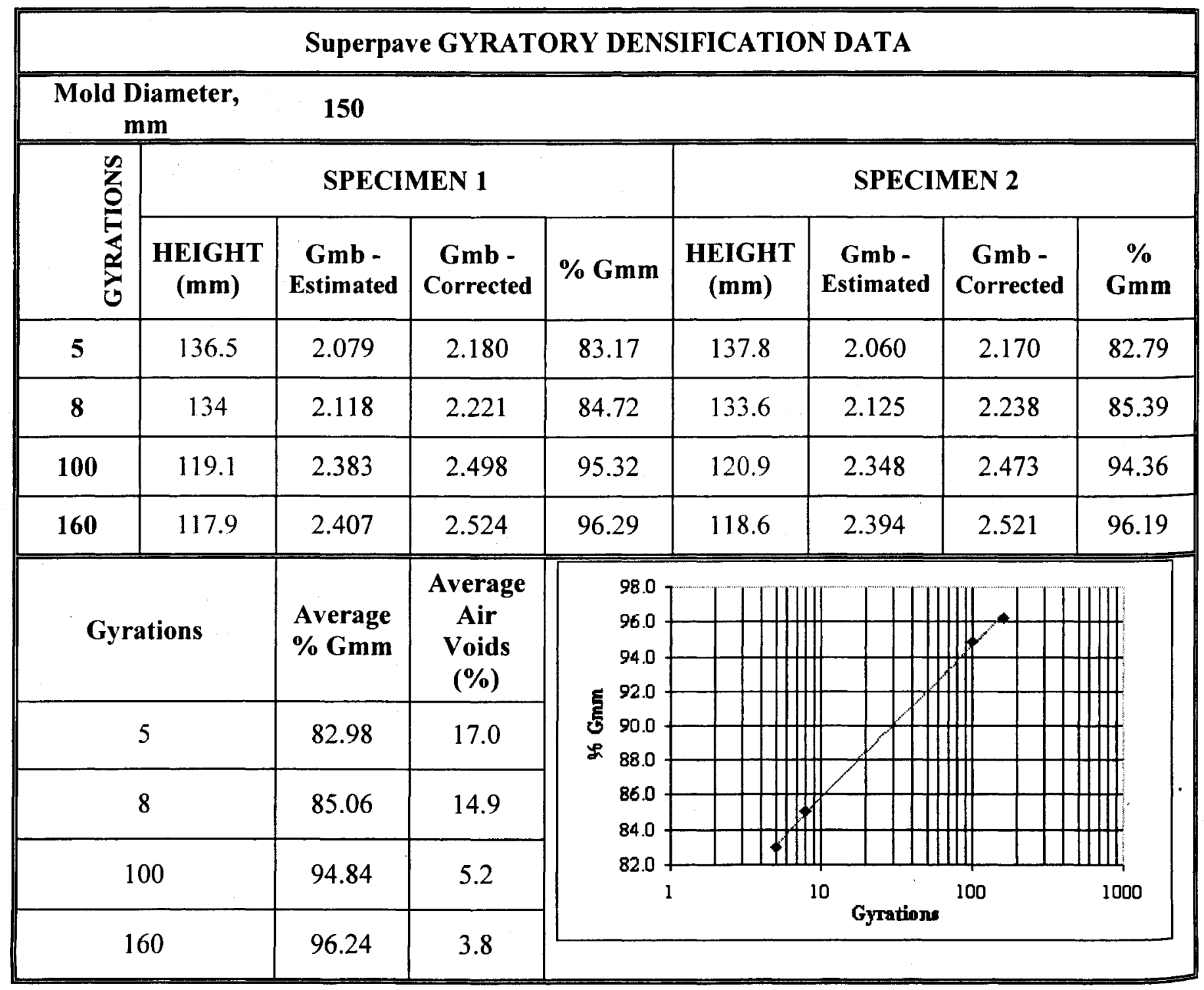


Table B.8 Superpave data for SMA mix design No 1B

\begin{tabular}{|l|c|c|}
\hline \multicolumn{1}{|c|}{ PARAMETER } & SPECIMEN 1 & SPECIMEN 2 \\
\hline A1: MASS OF COMPACTED SPECIMEN IN AIR & 5009 & 5000.2 \\
\hline A2: S.D.MASS IN AIR AFTER IMMERSSION IN H2O & 5029.6 & 5018.2 \\
\hline B1: MASS OF COMPACTED SPECIMEN IN WATER & 3040.2 & 3033.5 \\
\hline B2: VOLUME (= A2-B1) & 1989.4 & 1984.7 \\
\hline C: BULK REL. DENSITY (= A1/B2), Gmb Measured & 2.518 & 2.519 \\
\hline D: MAX. THEORITICAL DENSITY, Gmm & \multicolumn{2}{|c|}{2.614} \\
\hline
\end{tabular}

\section{Superpave GYRATORY DENSIFICATION DATA}

\begin{tabular}{|c|c|c|c|c|c|c|c|c||c||}
\hline $\begin{array}{c}\text { Mold Diameter, } \\
\text { mm }\end{array}$ \\
\hline
\end{tabular}


Table B.9 Superpave data for SMA mix design No.2

\begin{tabular}{|l|c|c|}
\hline \multicolumn{1}{|c|}{ PARAMETER } & SPECIMEN 1 & SPECIMEN 2 \\
\hline A1: MASS OF COMPACTED SPECIMEN IN AIR & 4998.9 & 5002.3 \\
\hline A2: S.D.MASS IN AIR AFTER IMMERSSION IN H ${ }_{2} \mathrm{O}$ & 5015.2 & 5017.3 \\
\hline B1: MASS OF COMPACTED SPECIMEN IN WATER & 3016.5 & 3012.3 \\
\hline B2: VOLUME (= A2-B1) & 1998.7 & 2005 \\
\hline C: BULK REL. DENSITY (= A1/B2), Gmb Measured & 2.501 & 2.495 \\
\hline D: MAX. THEORITICAL DENSITY, Gmm & & 2.640 \\
\hline
\end{tabular}

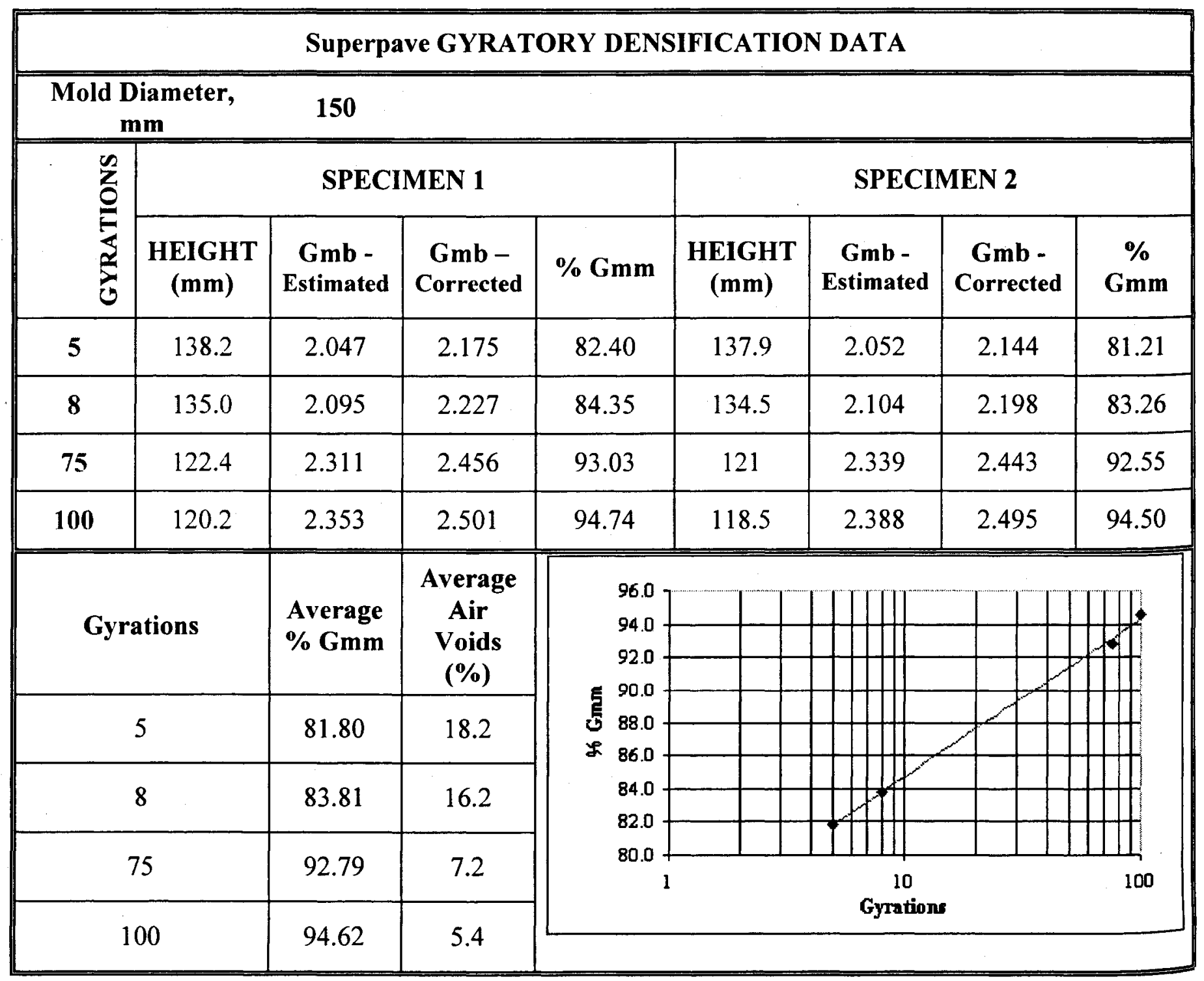


Table B.10 Superpave data for SMA mix design No.2

\begin{tabular}{|l|c|c|}
\hline \multicolumn{1}{|c|}{ PARAMETER } & SPECIMEN 1 & SPECIMEN 2 \\
\hline A1: MASS OF COMPACTED SPECIMEN IN AIR & 4995.5 & 4996.8 \\
\hline A2: S.D.MASS IN AIR AFTER IMMERSSION IN H $\mathrm{H}_{2} \mathrm{O}$ & 5021 & 5012.6 \\
\hline B1: MASS OF COMPACTED SPECIMEN IN WATER & 3035 & 3030.5 \\
\hline B2: VOLUME (= A2-B1) & 1986 & 1982.1 \\
\hline C: BULK REL. DENSITY (= A1/B2), Gmb Measured & 2.515 & 2.521 \\
\hline D: MAX. THEORITICAL DENSITY, Gmm & & 2.622 \\
\hline
\end{tabular}

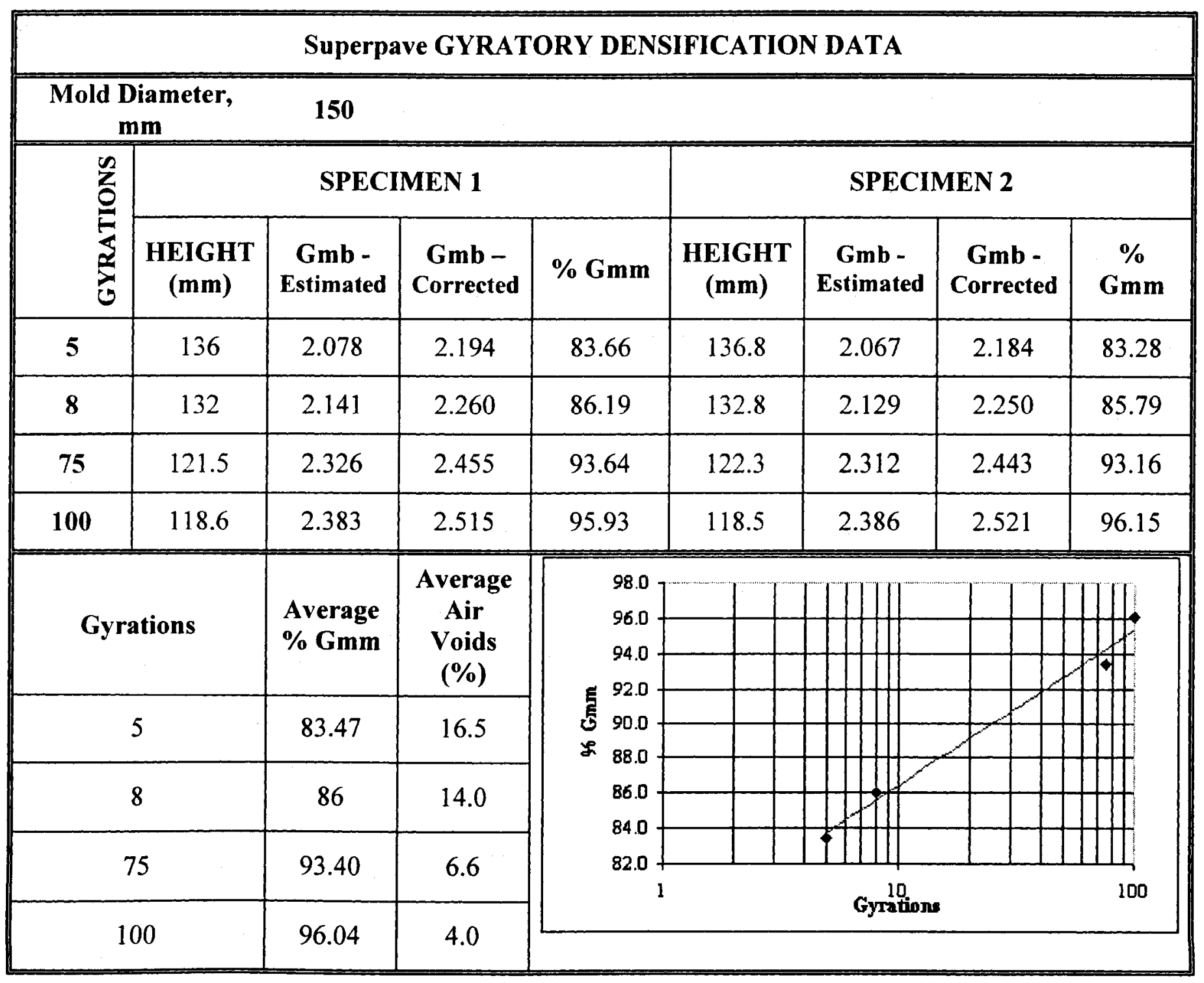


Table B.11 Superpave data for SMA mix design No.2

\begin{tabular}{|l|c|c|}
\hline \multicolumn{1}{|c|}{ PARAMETER } & SPECIMEN 1 & SPECIMEN 2 \\
\hline A1: MASS OF COMPACTED SPECIMEN IN AIR & 5002.2 & 4980.6 \\
\hline A2: S.D.MASS IN AIR AFTER IMMERSSION IN H $2 \mathrm{O}$ & 5030.2 & 5017.8 \\
\hline B1: MASS OF COMPACTED SPECIMEN IN WATER & 3052.4 & 3046.6 \\
\hline B2: VOLUME (= A2-B1) & 1977.8 & 1971.2 \\
\hline C: BULK REL. DENSITY (= A1/B2), Gmb Measured & 2.529 & 2.527 \\
\hline D: MAX. THEORITICAL DENSITY, Gmm & \multicolumn{2}{|c|}{2.590} \\
\hline
\end{tabular}

\begin{tabular}{|c|c|c|c|c|c|c|c|c|}
\hline \multicolumn{9}{|c|}{ Superpave GYRATORY DENSIFICATION DATA } \\
\hline \multicolumn{2}{|c|}{$\begin{array}{c}\begin{array}{c}\text { Mold Diameter, } \\
\mathrm{mm}\end{array} \\
\end{array}$} & \multicolumn{7}{|l|}{150} \\
\hline \multirow{2}{*}{ 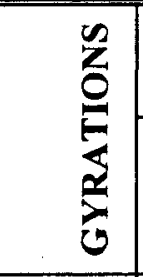 } & \multicolumn{4}{|c|}{ SPECIMEN 1} & \multicolumn{4}{|c|}{ SPECIMEN 2} \\
\hline & $\begin{array}{c}\text { HEIGHT } \\
(\mathbf{m m})\end{array}$ & $\begin{array}{c}\text { Gmb - } \\
\text { Estimated }\end{array}$ & $\begin{array}{c}\text { Gmb - } \\
\text { Corrected }\end{array}$ & $\% \mathbf{G m m}$ & $\begin{array}{c}\text { HEIGHT } \\
(\mathrm{mm})\end{array}$ & $\begin{array}{c}\text { Gmb - } \\
\text { Estimated }\end{array}$ & $\begin{array}{c}\text { Gmb - } \\
\text { Corrected }\end{array}$ & $\begin{array}{c}\% \\
\text { Gmm }\end{array}$ \\
\hline 5 & 137.9 & 2.052 & 2.190 & 84.55 & 137.1 & 2.055 & 2.200 & 84.96 \\
\hline 8 & 135.2 & 2.093 & 2.234 & 86.24 & 134 & 2.103 & 2.251 & 86.93 \\
\hline 75 & 122 & 2.320 & 2.475 & 95.57 & 121.2 & 2.325 & 2.489 & 96.11 \\
\hline 100 & 119.4 & 2.370 & 2.529 & 97.65 & 119.4 & 2.360 & 2.527 & 97.56 \\
\hline \multirow{3}{*}{\multicolumn{2}{|c|}{ Gyrations }} & Average & $\begin{array}{c}\text { Average } \\
\text { Air }\end{array}$ & \multirow{3}{*}{$\begin{array}{r}100.0 \\
98.0 \\
96.0 \\
94.0\end{array}$} & & & & \\
\hline & & $\%$ Gmm & Voids & & & & & $\mathbb{1}$ \\
\hline & & & (\%) & & & & & H \\
\hline \multicolumn{2}{|c|}{5} & 84.76 & 15.2 & $\begin{array}{ll}5 & 92.0 \\
5 & \end{array}$ & & & $F$ & $\pi$ \\
\hline \multirow{2}{*}{\multicolumn{2}{|c|}{8}} & & & & & 1010 & & H \\
\hline & & 86.58 & 13.4 & $86.0]$ & & W-1 & & TI \\
\hline \multirow{2}{*}{\multicolumn{2}{|c|}{75}} & & & 84.0 & & 1 & & ШI \\
\hline & & 95.84 & 4.2 & \multirow[t]{2}{*}{0.0} & \multirow{2}{*}{\multicolumn{4}{|c|}{$\begin{array}{c}10 \\
\text { Gyrations }\end{array}$}} \\
\hline \multicolumn{2}{|c|}{100} & 97.60 & 2.4 & & & & & \\
\hline
\end{tabular}


Table B.12 $\left.\mathrm{N}_{(\max }\right)$ verification for SMA mix design No.2

\begin{tabular}{|l|c|c|}
\hline \multicolumn{1}{|c|}{ PARAMETER } & SPECIMEN 1 & SPECIMEN 2 \\
\hline A1: MASS OF COMPACTED SPECIMEN IN AIR & 5019 & 5009 \\
\hline A2: S.D.MASS IN AIR AFTER IMMERSSION IN H2O & 5021 & 5026.6 \\
\hline B1: MASS OF COMPACTED SPECIMEN IN WATER & 3025 & 3039.8 \\
\hline B2: VOLUME (= A2-B1) & 1996 & 1986.8 \\
\hline C: BULK REL. DENSITY (=A1/B2), Gmb Measured & 2.515 & 2.521 \\
\hline D: MAX. THEORITICAL DENSITY, Gmm & & 2.622 \\
\hline
\end{tabular}

\section{Superpave GYRATORY DENSIFICATION DATA}

\begin{tabular}{|c|c|c|c|c|c|c|c|c|}
\hline \multicolumn{9}{|c|}{$\begin{array}{l}\text { Mold Diameter, } \\
\text { mm }\end{array}$} \\
\hline \multirow{2}{*}{$\sum_{0}^{\infty}$} & \multicolumn{4}{|c|}{ SPECIMEN 1} & \multicolumn{4}{|c|}{ SPECIMEN 2} \\
\hline & $\begin{array}{c}\text { HEIGHT } \\
(\mathrm{mm})\end{array}$ & $\begin{array}{c}\text { Gmb - } \\
\text { Estimated }\end{array}$ & $\begin{array}{c}\text { Gmb - } \\
\text { Corrected }\end{array}$ & $\% \mathrm{Gmm}$ & $\underset{(\mathbf{m m})}{\text { HEIGHT }}$ & $\begin{array}{c}\text { Gmb - } \\
\text { Estimated }\end{array}$ & $\begin{array}{c}\text { Gmb - } \\
\text { Corrected }\end{array}$ & $\begin{array}{c}\% \\
\text { Gmm }\end{array}$ \\
\hline 5 & 137 & 2.073 & 2.138 & 81.55 & 137.6 & 2.060 & $2.138^{\circ}$ & 81.55 \\
\hline 8 & 132.6 & 2.142 & 2.209 & 84.26 & 133.2 & 2.128 & 2.209 & 84.24 \\
\hline 100 & 120 & 2.367 & 2.441 & 93.10 & 119.7 & 2.368 & 2.458 & 93.74 \\
\hline 160 & 116.5 & 2.438 & 2.515 & 95.90 & 116.7 & 2.429 & 2.521 & 96.15 \\
\hline \multirow{3}{*}{\multicolumn{2}{|c|}{ Gyrations }} & Average & $\begin{array}{c}\text { Average } \\
\text { Air }\end{array}$ & \multirow{5}{*}{$\begin{array}{l}98.0 \\
96.0 \\
94.0 \\
92.0 \\
90.0 \\
88.0 \\
88.0\end{array}$} & & & & II! \\
\hline & & \% Gmm & Voids & & & & $\Rightarrow$ & $t$ \\
\hline & & & $(\%)$ & & & & & \# \\
\hline \multicolumn{2}{|c|}{5} & 81.55 & 18.5 & & & & & III \\
\hline \multirow{2}{*}{\multicolumn{2}{|c|}{8}} & 0105 & 150 & & & & & \\
\hline & & 84.25 & 15.8 & 84. & t & & & \#I \\
\hline \multicolumn{2}{|c|}{100} & 93.42 & 6.6 & $80.0 t$ & & & & Ш1 \\
\hline \multirow{2}{*}{\multicolumn{2}{|c|}{160}} & & & & & Gyrat & & \\
\hline & & 96.03 & 4.0 & & & & & \\
\hline
\end{tabular}


Table B.13 Superpave data for SMA Mix design No.3

\begin{tabular}{|l|c|c|}
\hline \multicolumn{1}{|c|}{ PARAMETER } & SPECIMEN 1 & SPECIMEN 2 \\
\hline A1: MASS OF COMPACTED SPECIMEN IN AIR & 5055 & 5002 \\
\hline A2: S.D.MASS IN AIR AFTER IMMERSSION IN H${ }_{2} \mathrm{O}$ & 5090 & 5055.3 \\
\hline B1: MASS OF COMPACTED SPECIMEN IN WATER & 3065.6 & 3051.2 \\
\hline B2: VOLUME (= A2-B1) & 2024.4 & 2004.1 \\
\hline C: BULK REL. DENSITY (= A1/B2), Gmb Measured & 2.497 & 2.496 \\
\hline D: MAX. THEORITICAL DENSITY, Gmm & \multicolumn{2}{|c|}{2.642} \\
\hline
\end{tabular}

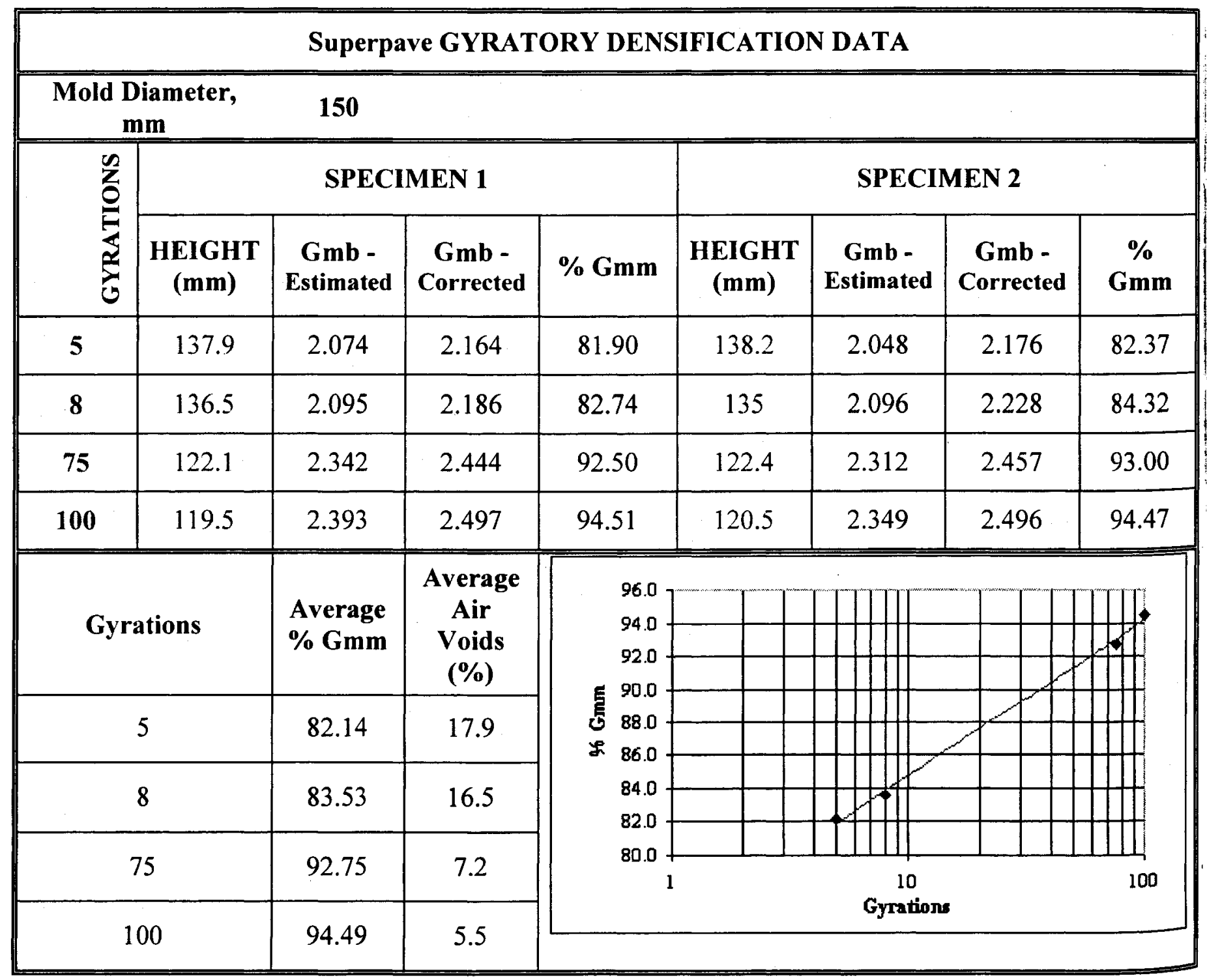


Table B.14 Superpave data for SMA Mix design No.3

\begin{tabular}{|l|c|c|}
\hline \multicolumn{1}{|c|}{ PARAMETER } & SPECIMEN 1 & SPECIMEN 2 \\
\hline A1: MASS OF COMPACTED SPECIMEN IN AIR & 5078.6 & 5059 \\
\hline A2: S.D.MASS IN AIR AFTER IMMERSSION IN H $\mathrm{H}_{2} \mathrm{O}$ & 5094.8 & 5068.3 \\
\hline B1: MASS OF COMPACTED SPECIMEN IN WATER & 3072.5 & 3055.4 \\
\hline B2: VOLUME (=A2-B1) & 2022.3 & 2012.9 \\
\hline C: BULK REL. DENSITY (=A1/B2), Gmb Measured & 2.511 & 2.513 \\
\hline D: MAX. THEORITICAL DENSITY, Gmm & & 2.618 \\
\hline
\end{tabular}

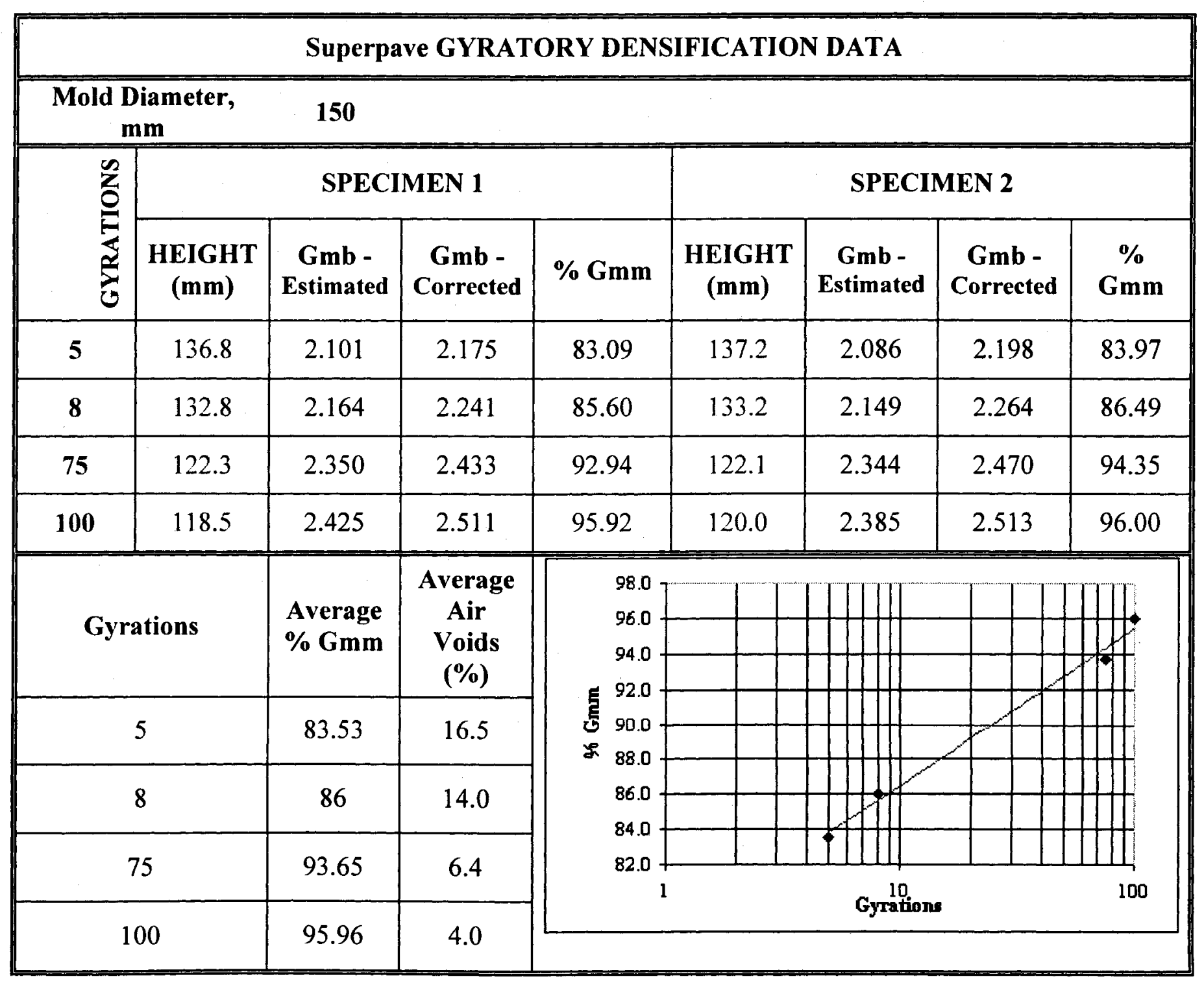


Table B.15 Superpave data for SMA Mix design No.3

\begin{tabular}{|l|c|c|}
\hline \multicolumn{1}{|c|}{ PARAMETER } & SPECIMEN 1 & SPECIMEN 2 \\
\hline A1: MASS OF COMPACTED SPECIMEN IN AIR & 5055.6 & 5045.9 \\
\hline A2: S.D.MASS IN AIR AFTER IMMERSSION IN H $2 \mathrm{O}$ & 5080.9 & 5075.6 \\
\hline B1: MASS OF COMPACTED SPECIMEN IN WATER & 3073 & 3074.6 \\
\hline B2: VOLUME (= A2-B1) & 2007.9 & 2001 \\
\hline C: BULK REL. DENSITY (= A1/B2), Gmb Measured & 2.518 & 2.522 \\
\hline D: MAX. THEORITICAL DENSITY, Gmm & & 2.599 \\
\hline
\end{tabular}

\section{Superpave GYRATORY DENSIFICATION DATA}

\begin{tabular}{|c|c|c|c|c|c|c|c|c|c||}
\hline \multicolumn{10}{|c|}{$\begin{array}{c}\text { Mold Diameter, } \\
\text { mm }\end{array}$} \\
\hline
\end{tabular}


Table B.16 $\mathrm{N}_{(\max )}$ verification of SMA mix design No.3

\begin{tabular}{|l|c|c|}
\hline \multicolumn{1}{|c|}{ PARAMETER } & SPECIMEN 1 & SPECIMEN 2 \\
\hline A1: MASS OF COMPACTED SPECIMEN IN AIR & 5005 & 5055 \\
\hline A2: S.D.MASS IN AIR AFTER IMMERSSION IN H ${ }_{2} \mathrm{O}$ & 5065.3 & 5070.6 \\
\hline B1: MASS OF COMPACTED SPECIMEN IN WATER & 3070 & 3063.4 \\
\hline B2: VOLUME (= A2-B1) & 1995.3 & 2007.2 \\
\hline C: BULK REL. DENSITY (= A1/B2), Gmb Measured & 2.508 & 2.518 \\
\hline D: MAX. THEORITICAL DENSITY, Gmm & & 2.618 \\
\hline
\end{tabular}

\section{Superpave GYRATORY DENSIFICATION DATA}

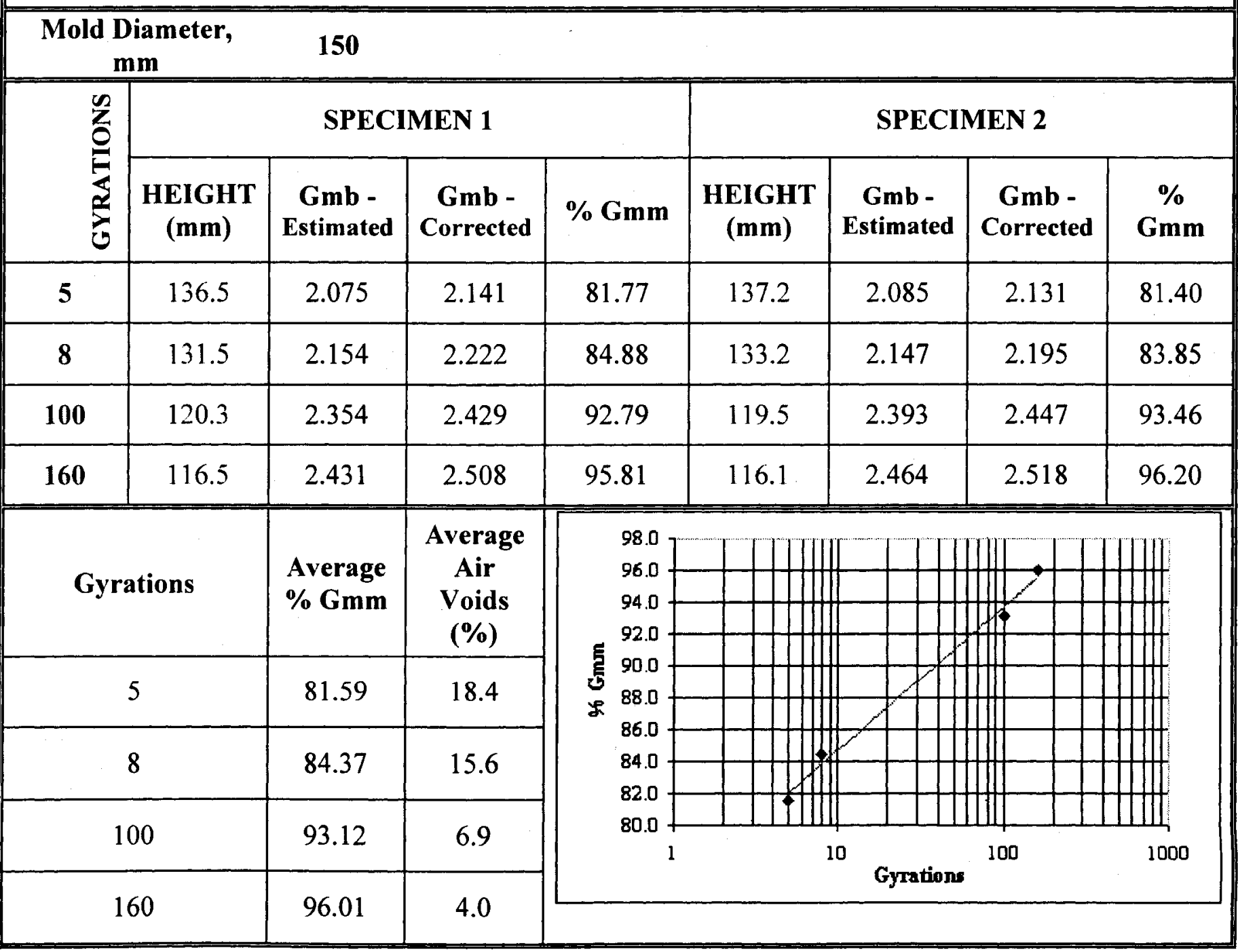


Table B.17 Superpave data for SMA mix design No.4

\begin{tabular}{|l|c|c|}
\hline \multicolumn{1}{|c|}{ PARAMETER } & SPECIMEN 1 & SPECIMEN 2 \\
\hline A1: MASS OF COMPACTED SPECIMEN IN AIR & 5021.2 & 5020 \\
\hline A2: S.D.MASS IN AIR AFTER IMMERSSION IN H ${ }_{2} \mathrm{O}$ & 5048.1 & 5046.5 \\
\hline B1: MASS OF COMPACTED SPECIMEN IN WATER & 3026.6 & 3022.1 \\
\hline B2: VOLUME (= A2-B1) & 2021.5 & 2024.4 \\
\hline C: BULK REL. DENSITY (= A1/B2), Gmb Measured & 2.484 & 2.480 \\
\hline D: MAX. THEORITICAL DENSITY, Gmm & & 2.640 \\
\hline
\end{tabular}

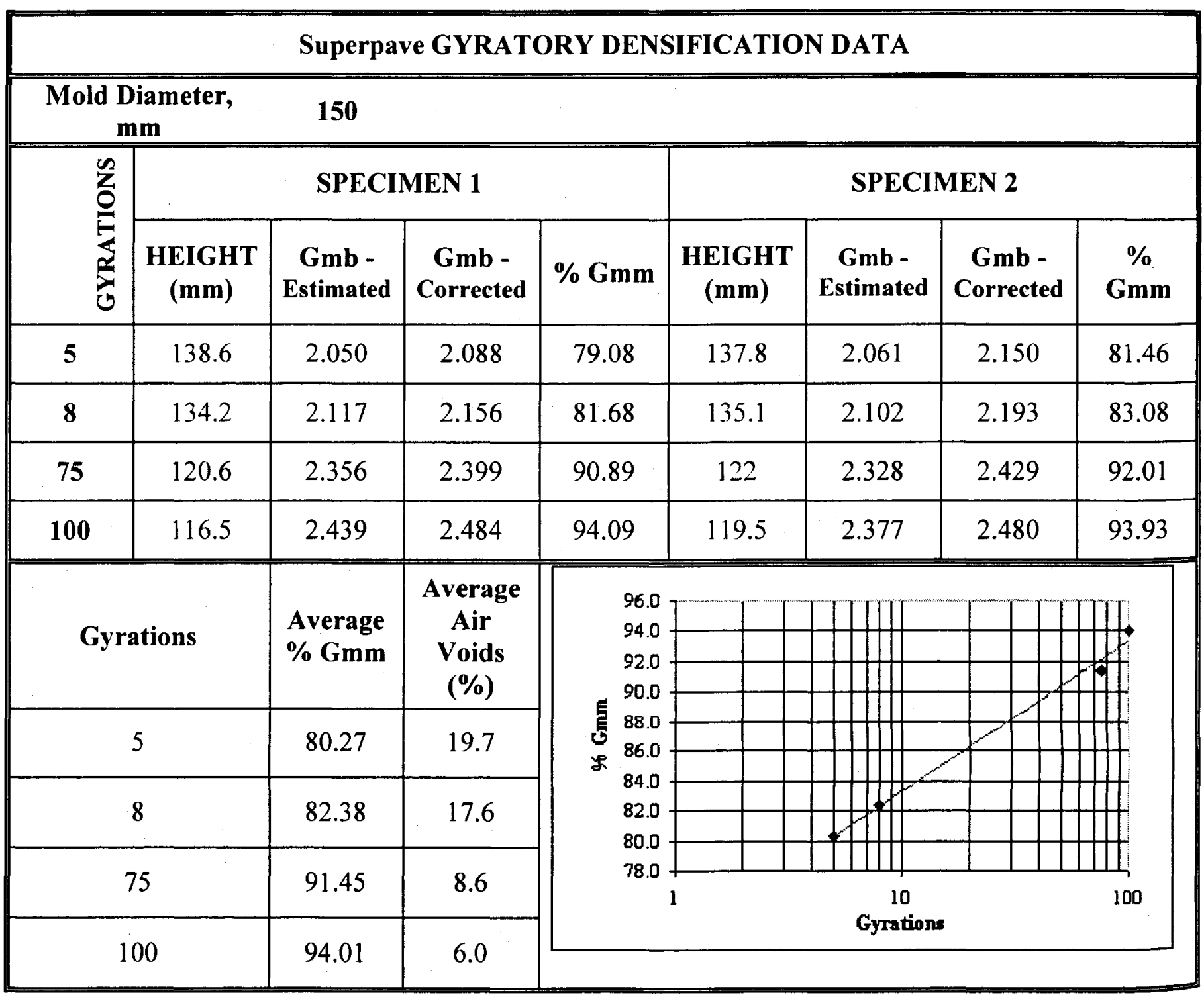


Table B.18 Superpave data for SMA mix design No.4

\begin{tabular}{|l|c|c|}
\hline \multicolumn{1}{|c|}{ PARAMETER } & SPECIMEN 1 & SPECIMEN 2 \\
\hline A1: MASS OF COMPACTED SPECIMEN IN AIR & 4995.5 & 4996.8 \\
\hline A2: S.D.MASS IN AIR AFTER IMMERSSION IN $\mathrm{H}_{2} \mathrm{O}$ & 5005.3 & 5008.7 \\
\hline B1: MASS OF COMPACTED SPECIMEN IN WATER & 3018 & 3020.5 \\
\hline B2: VOLUME (= A2-B1) & 1987.3 & 1988.2 \\
\hline C: BULK REL. DENSITY (= A1/B2), Gmb Measured & 2.514 & 2.513 \\
\hline D: MAX. THEORITICAL DENSITY, Gmm & & 2.617 \\
\hline
\end{tabular}

Superpave GYRATORY DENSIFICATION DATA

Mold Diameter, $\mathbf{m m} \quad 150$

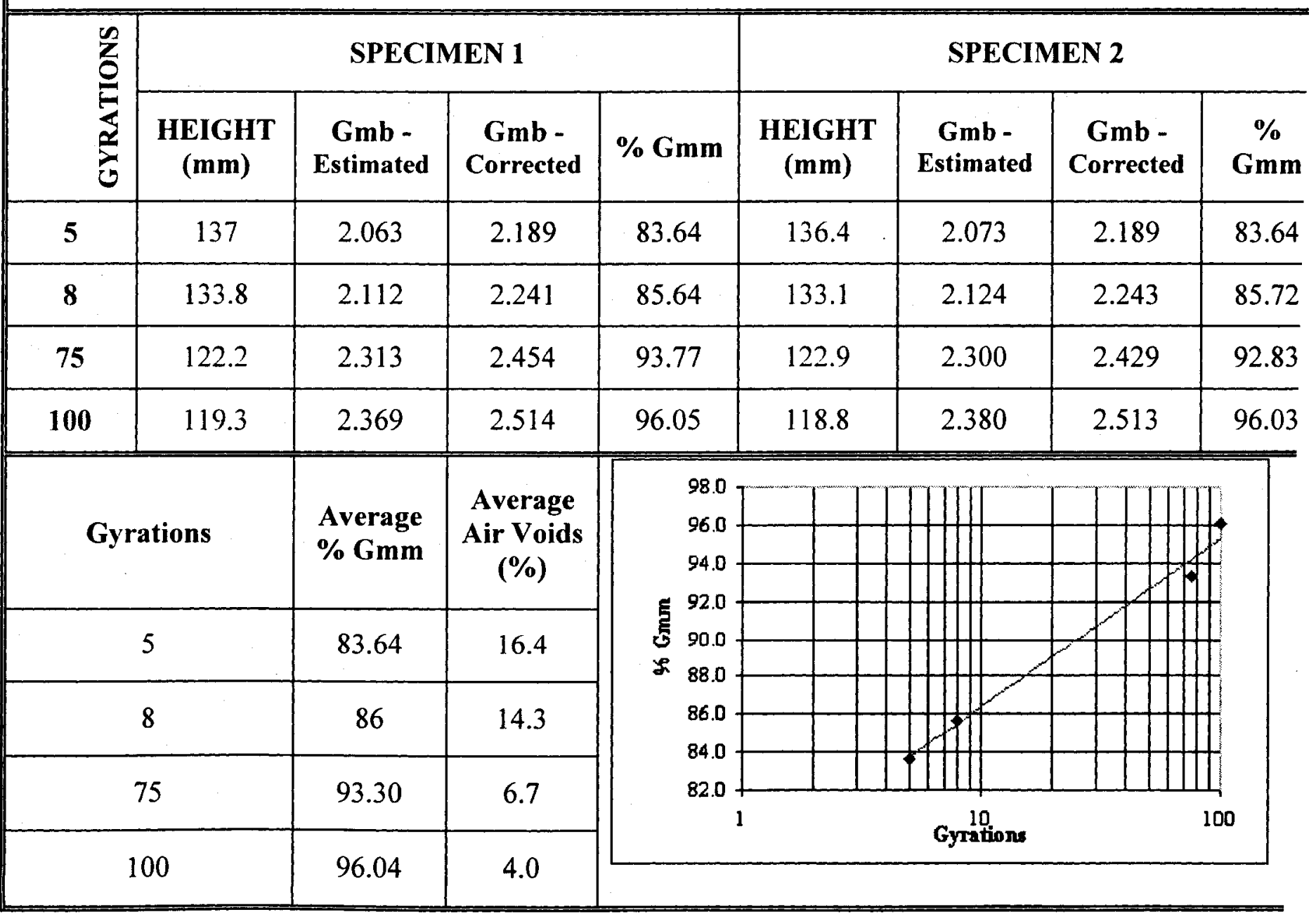


Table B.19 Superpave data for SMA mix design No.4

\begin{tabular}{|l|c|c|}
\hline \multicolumn{1}{|c|}{ PARAMETER } & SPECIMEN 1 & SPECIMEN 2 \\
\hline A1: MASS OF COMPACTED SPECIMEN IN AIR & 4991.5 & 4987.1 \\
\hline A2: S.D.MASS IN AIR AFTER IMMERSSION IN H $\mathrm{H}_{2} \mathrm{O}$ & 4998.7 & 4994.8 \\
\hline B1: MASS OF COMPACTED SPECIMEN IN WATER & 3013 & 3010.6 \\
\hline B2: VOLUME (= A2-B1) & 1985.7 & 1984.2 \\
\hline C: BULK REL. DENSITY (= A1/B2), Gmb Measured & 2.514 & 2.513 \\
\hline D: MAX. THEORITICAL DENSITY, Gmm & \multicolumn{2}{|c|}{2.599} \\
\hline
\end{tabular}

\section{Superpave GYRATORY DENSIFICATION DATA}

\begin{tabular}{|c|c|c|c|c|c|c|c|c|}
\hline \multicolumn{2}{|c|}{$\begin{array}{l}\text { Mold Diameter, } \\
\text { mm }\end{array}$} & \multicolumn{7}{|l|}{150} \\
\hline \multirow{2}{*}{ 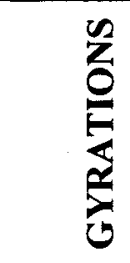 } & \multicolumn{4}{|c|}{ SPECIMEN 1} & \multicolumn{4}{|c|}{ SPECIMEN 2} \\
\hline & $\underset{(\mathrm{mm})}{\text { HEIGHT }}$ & $\begin{array}{c}\text { Gmb - } \\
\text { Estimated }\end{array}$ & $\begin{array}{c}\text { Gmb - } \\
\text { Corrected }\end{array}$ & $\% \mathrm{Gmm}$ & $\begin{array}{c}\text { HEIGHT } \\
(\mathbf{m m})\end{array}$ & $\begin{array}{c}\text { Gmb - } \\
\text { Estimated }\end{array}$ & $\begin{array}{c}\text { Gmb - } \\
\text { Corrected }\end{array}$ & $\begin{array}{c}\% \\
\text { Gmm }\end{array}$ \\
\hline 5 & 136.4 & 2.071 & 2.186 & 84.10 & 136 & 2.075 & 2.194 & 84.40 \\
\hline 8 & 133.2 & 2.120 & 2.238 & 86.12 & 132.6 & 2.128 & 2.250 & 86.57 \\
\hline 75 & 120.1 & 2.352 & 2.482 & 95.51 & 121 & 2.332 & 2.466 & 94.87 \\
\hline 100 & 118.6 & 2.381 & 2.514 & 96.72 & 118.7 & 2.377 & 2.513 & 96.71 \\
\hline \multicolumn{2}{|c|}{ Gyrations } & $\begin{array}{l}\text { Average } \\
\% \text { Gmm }\end{array}$ & $\begin{array}{c}\text { Average } \\
\text { Air } \\
\text { Voids } \\
\end{array}$ & $\left.\begin{array}{l}98.0 \\
96.0 \\
94.0 \\
9.0\end{array}\right]$ & & & & 4 \\
\hline \multirow{2}{*}{\multicolumn{2}{|c|}{5}} & & & 50 & & & & | \\
\hline & & 84.25 & 15.7 & $\begin{array}{ll}5 & 90.0- \\
2 & 880 .\end{array}$ & & & & † \\
\hline \multicolumn{2}{|c|}{8} & 86.34 & 13.7 & 86.0 & & & & tI \\
\hline \multicolumn{2}{|c|}{75} & 95.19 & 4.8 & \multirow[t]{2}{*}{1} & \multirow{2}{*}{\multicolumn{4}{|c|}{ Gyrations }} \\
\hline \multirow{2}{*}{\multicolumn{2}{|c|}{100}} & & & & & & & \\
\hline & & 96.71 & 3.3 & & & & & \\
\hline
\end{tabular}


Table B. $20 \mathrm{~N}_{(\max )}$ verification of SMA mix design No.4

\begin{tabular}{|l|c|c|}
\hline \multicolumn{1}{|c|}{ PARAMETER } & SPECIMEN 1 & SPECIMEN 2 \\
\hline A1: MASS OF COMPACTED SPECIMEN IN AIR & 5012.3 & 4998.6 \\
\hline A2: S.D.MASS IN AIR AFTER IMMERSSION IN H ${ }_{2} \mathrm{O}$ & 5021 & 5029.6 \\
\hline B1: MASS OF COMPACTED SPECIMEN IN WATER & 3030.6 & 3038.6 \\
\hline B2: VOLUME (= A2-B1) & 1990.4 & 1991 \\
\hline C: BULK REL. DENSITY (= A1/B2), Gmb Measured & 2.518 & 2.511 \\
\hline D: MAX. THEORITICAL DENSITY, Gmm & & 2.617 \\
\hline
\end{tabular}

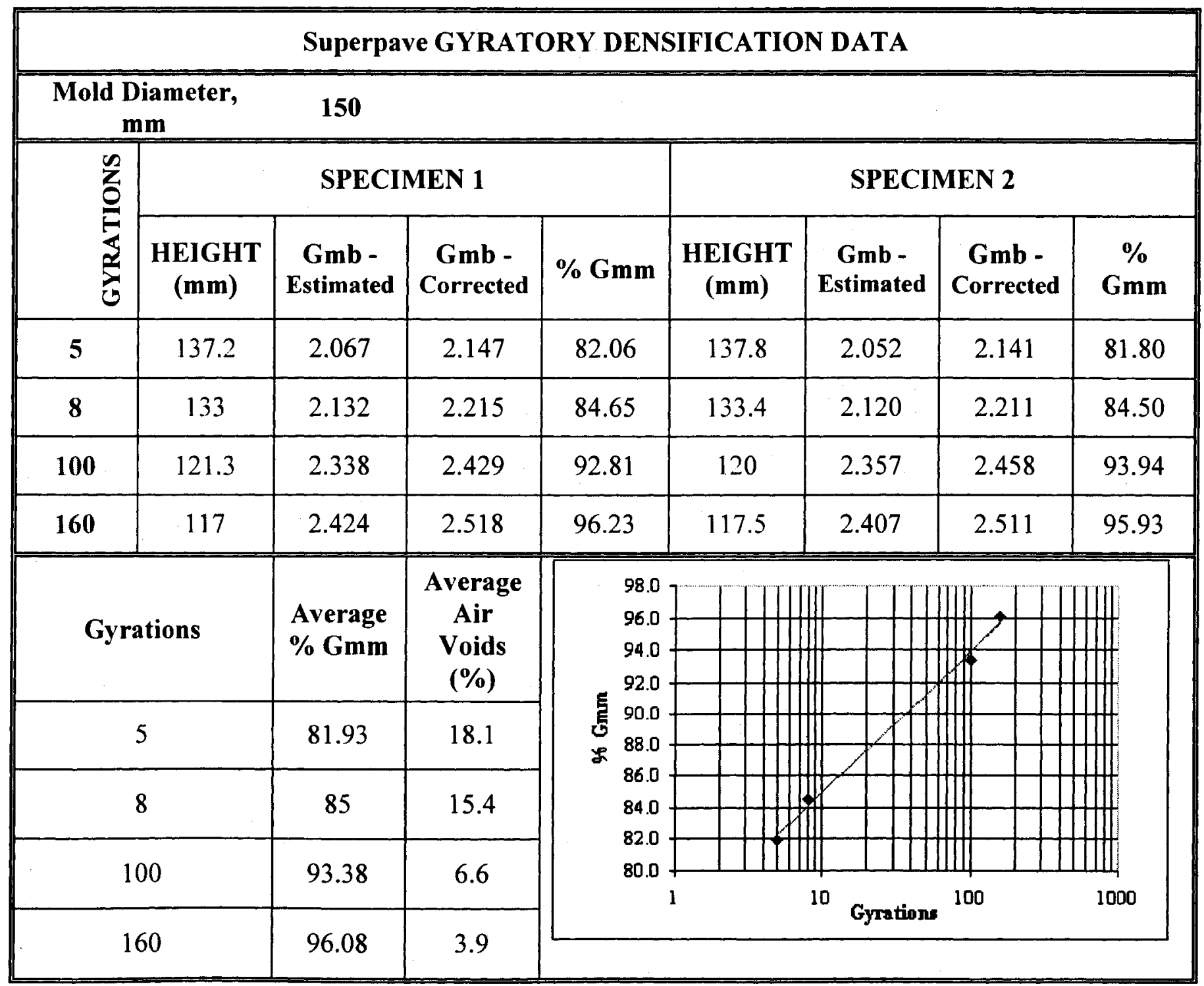


Table B.21 Superpave data for SMA mix design.No.5

\begin{tabular}{|l|c|c|}
\hline \multicolumn{1}{|c|}{ PARAMETER } & SPECIMEN 1 & SPECIMEN 2 \\
\hline A1: MASS OF COMPACTED SPECIMEN IN AIR & 5005.6 & 5010.7 \\
\hline A2: S.D.MASS IN AIR AFTER IMMERSSION IN H2O & 5035.6 & 5022.9 \\
\hline B1: MASS OF COMPACTED SPECIMEN IN WATER & 3018.9 & 2998 \\
\hline B2: VOLUME (= A2-B1) & 2016.7 & 2024.9 \\
\hline C: BULK REL. DENSITY (= A1/B2), Gmb Measured & 2.482 & 2.475 \\
\hline D: MAX. THEORITICAL DENSITY, Gmm & \multicolumn{2}{|c|}{2.618} \\
\hline
\end{tabular}

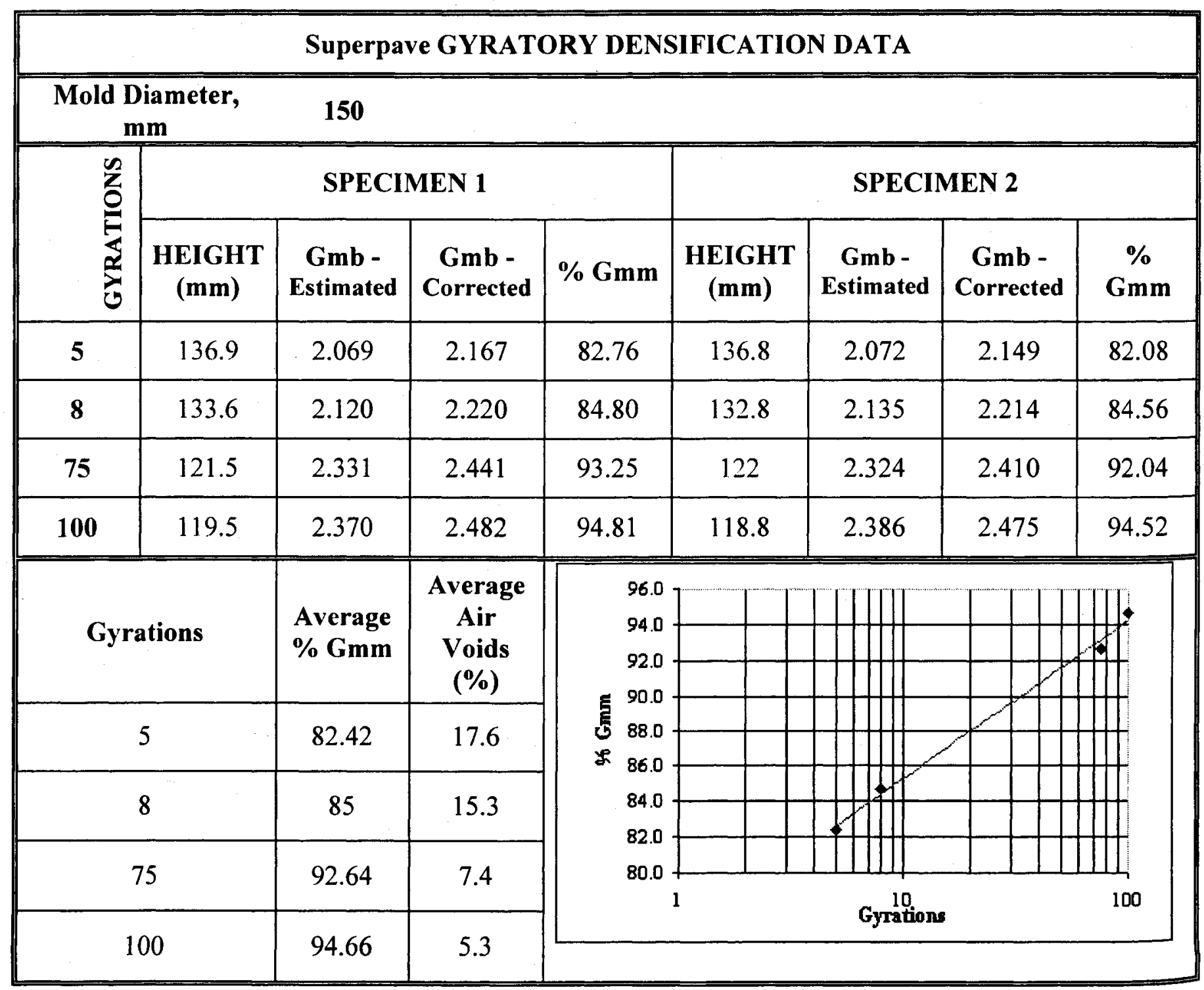


Table B.22 Superpave data for SMA mix design.No.5

\begin{tabular}{|l|c|c|}
\hline \multicolumn{1}{|c|}{ PARAMETER } & SPECIMEN 1 & SPECIMEN 2 \\
\hline A1: MASS OF COMPACTED SPECIMEN IN AIR & 4998.6 & 5010.6 \\
\hline A2: S.D.MASS IN AIR AFTER IMMERSSION IN H ${ }_{2} \mathrm{O}$ & 5017.9 & 5015.6 \\
\hline B1: MASS OF COMPACTED SPECIMEN IN WATER & 3018.5 & 3003.6 \\
\hline B2: VOLUME (= A2-B1) & 1999.4 & 2012 \\
\hline C: BULK REL. DENSITY (= A1/B2), Gmb Measured & 2.500 & 2.490 \\
\hline D: MAX. THEORITICAL DENSITY, Gmm & \multicolumn{2}{|c|}{2.600} \\
\hline
\end{tabular}

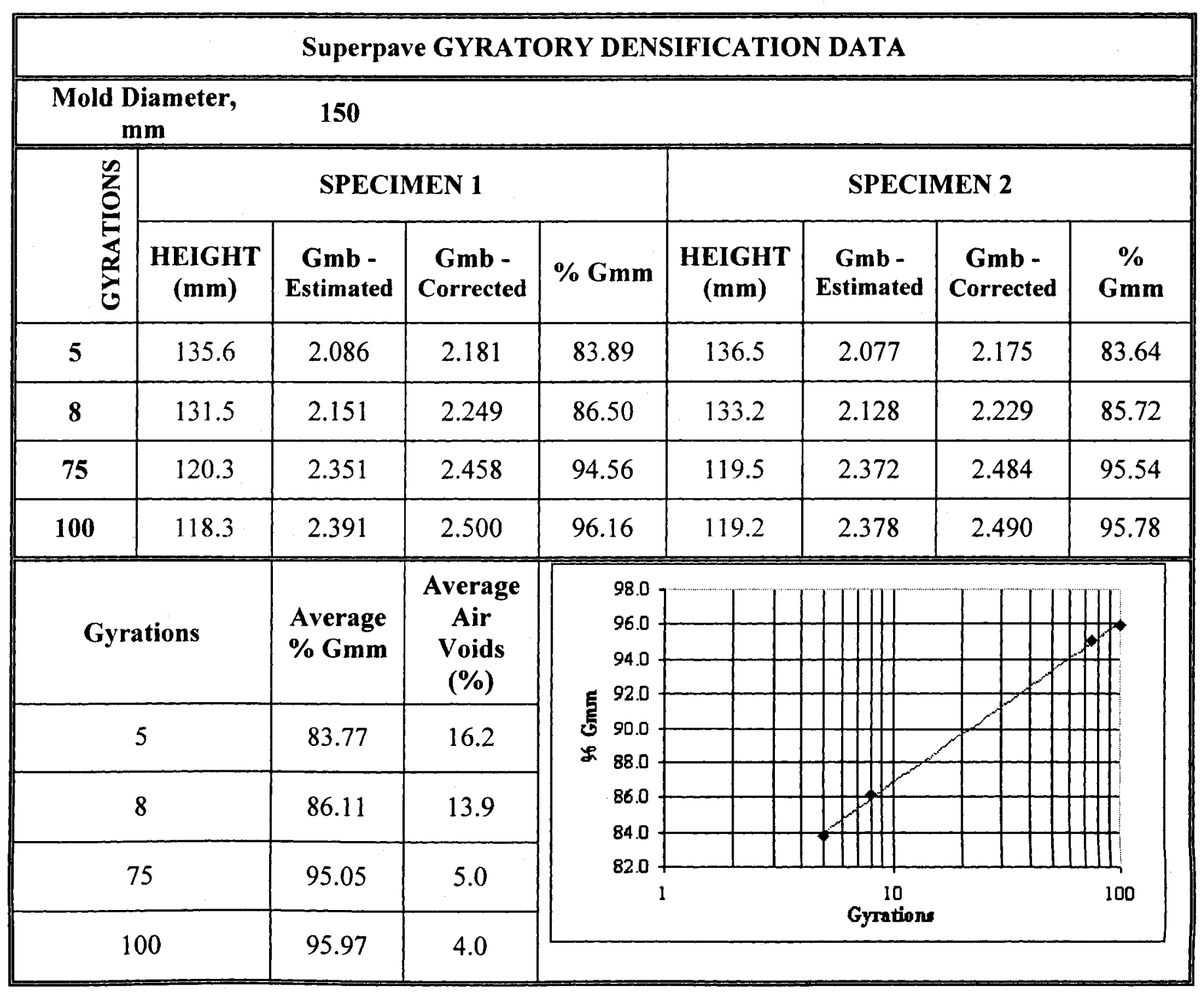


Table B.23 Superpave data for SMA mix design.No.5

\begin{tabular}{|l|c|c|}
\hline \multicolumn{1}{|c|}{ PARAMETER } & SPECIMEN 1 & SPECIMEN 2 \\
\hline A1: MASS OF COMPACTED SPECIMEN IN AIR & 5012.6 & 5010.9 \\
\hline A2: S.D.MASS IN AIR AFTER IMMERSSION IN H ${ }_{2} \mathrm{O}$ & 5024.6 & 5019.5 \\
\hline B1: MASS OF COMPACTED SPECIMEN IN WATER & 3025 & 3020 \\
\hline B2: VOLUME (= A2-B1) & 1999.6 & 1999.5 \\
\hline C: BULK REL. DENSITY (= A1/B2), Gmb Measured & 2.507 & 2.506 \\
\hline D: MAX. THEORITICAL DENSITY, Gmm & & 2.580 \\
\hline
\end{tabular}

\section{Superpave GYRATORY DENSIFICATION DATA}

\begin{tabular}{|c|c|c|c|c|c|c|c|c||c||}
\hline \hline $\begin{array}{c}\text { Mold Diameter, } \\
\text { mm }\end{array}$ \\
\hline \hline
\end{tabular}


Table B. $\left.24 \mathrm{~N}_{(\max }\right)$ verification for SMA mix design No. 5

\begin{tabular}{|l|c|c|}
\hline \multicolumn{1}{|c|}{ PARAMETER } & SPECIMEN 1 & SPECIMEN 2 \\
\hline A1: MASS OF COMPACTED SPECIMEN IN AIR & 5011.2 & 5002.6 \\
\hline A2: S.D.MASS IN AIR AFTER IMMERSSION IN H ${ }_{2} \mathrm{O}$ & 5025.9 & 5021.3 \\
\hline B1: MASS OF COMPACTED SPECIMEN IN WATER & 3030.2 & 3032.5 \\
\hline B2: VOLUME (= A2-B1) & 1995.7 & 1988.8 \\
\hline C: BULK REL. DENSITY (= A1/B2), Gmb Measured & 2.511 & 2.515 \\
\hline D: MAX. THEORITICAL DENSITY, Gmm & \multicolumn{2}{|c|}{2.614} \\
\hline
\end{tabular}

\begin{tabular}{|c|c|c|c|c|c|c|c|c|}
\hline \multicolumn{9}{|c|}{ Superpave GYRATORY DENSIFICATION DATA } \\
\hline \multicolumn{2}{|c|}{$\begin{array}{l}\text { Mold Diameter, } \\
\mathrm{mm}\end{array}$} & \multicolumn{7}{|l|}{150} \\
\hline \multirow{2}{*}{ 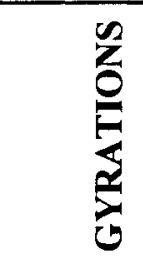 } & \multicolumn{4}{|c|}{ SPECIMEN 1} & \multicolumn{4}{|c|}{ SPECIMEN 2} \\
\hline & $\begin{array}{c}\text { HEIGHT } \\
(\mathbf{m m})\end{array}$ & $\underset{\text { Estimated }}{\text { Gmb - }}$ & $\begin{array}{c}\text { Gmb - } \\
\text { Corrected }\end{array}$ & $\%$ Gmm & $\begin{array}{c}\text { HEIGHT } \\
(\mathbf{m m})\end{array}$ & $\begin{array}{c}\text { Gmb - } \\
\text { Estimated }\end{array}$ & $\begin{array}{c}\text { Gmb - } \\
\text { Corrected }\end{array}$ & $\begin{array}{c}\% \\
\text { Gmm }\end{array}$ \\
\hline 5 & 137.9 & 2.056 & 2.105 & 80.53 & 136.5 & 2.074 & 2.119 & 81.07 \\
\hline 8 & 134.7 & 2.105 & 2.155 & 82.44 & 133 & 2.128 & 2.175 & 83.20 \\
\hline 100 & 119.1 & 2.381 & 2.437 & 93.24 & 120.9 & 2.341 & 2.393 & 91.53 \\
\hline 160 & 115.6 & 2.453 & 2.511 & 96.06 & 115 & 2.461 & 2.515 & 96.23 \\
\hline \multirow{3}{*}{\multicolumn{2}{|c|}{ Gyrations }} & \multirow{3}{*}{$\begin{array}{l}\text { Average } \\
\% \mathrm{Gmm}\end{array}$} & \multirow{3}{*}{$\begin{array}{c}\text { Average } \\
\text { Air } \\
\text { Voids } \\
(\%)\end{array}$} & \multirow{3}{*}{$\begin{array}{l}98.0 \\
96.0 \\
94.0 \\
92.0\end{array}$} & & & & IIII \\
\hline & & & & & & & $\angle$ & III \\
\hline & & & & & & & - & 卅 \\
\hline \multirow{2}{*}{\multicolumn{2}{|c|}{5}} & 80.80 & 19.2 & 88.0 & & 7 & & \# \\
\hline & & & & & & 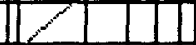 & 5 & 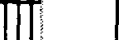 \\
\hline \multirow{2}{*}{\multicolumn{2}{|c|}{8}} & 82.82 & 17.2 & 82.0 & & & 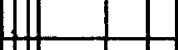 & III \\
\hline & & & & 80.0 & & & & III \\
\hline \multicolumn{2}{|c|}{100} & 92.38 & 7.6 & & & \multirow{2}{*}{\multicolumn{2}{|c|}{${ }^{0}$ Gyrations 100}} & 1000 \\
\hline \multicolumn{2}{|c|}{160} & 96.14 & 3.9 & & & & & \\
\hline
\end{tabular}




\section{Appendix C}

\section{Tensile Strength Ratio \& Draindown}


Table C.1 TSR result for SMA mix design No.1

\begin{tabular}{||l|c|c|c|c|c|c||}
\hline \multicolumn{7}{|c|}{ TENSILE STRENGTH RATIO CALCULATION SHEET } \\
\hline Sample Identification & 1 & 2 & 3 & 4 & 5 & 6 \\
\hline Diameter (mm) & 150 & 150 & 150 & 150 & 150 & 150 \\
\hline Thickness (mm) & 95 & 95 & 95 & 95 & 95 & 95 \\
\hline Dry Mass in Air (gm) & 3992.3 & 4000.4 & 3994.7 & 3995.8 & 3995.7 & 4006.2 \\
\hline SSD Mass (gm) & 4011.3 & 4017.7 & 4012.3 & 4014.2 & 4015 & 4022 \\
\hline Mass in Water (gm) & 2398 & 2405 & 2397.5 & 2397.4 & 2394.8 & 2400.3 \\
\hline Volume (cc) & 1613.3 & 1612.7 & 1614.8 & 1616.8 & 1620.2 & 1621.7 \\
\hline Bulk Specific Gravity & 2.475 & 2.481 & 2.474 & 2.471 & 2.466 & 2.470 \\
\hline Maximum Specific Gravity & 2.622 & 2.622 & 2.622 & 2.622 & 2.622 & 2.622 \\
\hline$\%$ Air Voids & 5.62 & 5.39 & 5.65 & 5.74 & 5.94 & 5.78 \\
\hline Volume of Air Voids & 90.68 & 86.99 & 91.27 & 92.85 & 96.29 & 93.78 \\
\hline Load (N) & 30517 & 31210 & 32015 & & & \\
\hline Saturated (min) & & & & & & \\
\hline Thickness (mm) & & & & 94.5 & 95.6 & 94.8 \\
\hline SSD Mass (gm) & & & & 4063 & 4060.3 & 4072.3 \\
\hline Volume of Absorbed water & & & & 67.2 & 64.6 & 66.1 \\
\hline$\%$ Saturation & & & & 72.38 & 67.09 & 70.48 \\
\hline Load (N) & & & & 27513 & 28210 & 29510 \\
\hline Dry Strength & 1364.04 & 1395.02 & 1431.00 & & & \\
\hline Wet Strength & & & & 1236.28 & 1253.01 & 1321.81 \\
\hline TSR (\%) & 90.63 & 89.82 & 92.37 & & & \\
\hline Average TSR (\%) & & & 90.94 & & \\
\hline
\end{tabular}

Table C.2 Drain down result for SMA Mix design No.1

\begin{tabular}{||l|c|c|c|}
\hline \multicolumn{4}{|c|}{ SMA Drain Down Test Report } \\
\hline Before Oven Treatment & Test No.1 & Test No.2 & \\
\hline Mass of Paper plate to the nearest 0.1g & 1023.50 & 1015.7 & \\
\hline After Oven treatment one hour & 1024.80 & 1016.8 & \\
\hline Mass of Paper plate to the nearest 0.1g & 1.30 & 1.1 & \\
\hline Drain down (\%) & 0.13 & 0.11 & \\
\hline Average Drain Down (\%) & \multicolumn{3}{|c|}{0.12} \\
\hline
\end{tabular}


Table C. 3 TSR Result for SMA Mix design No. 2

\begin{tabular}{||l|c|c|c|c|c|c||}
\hline \multicolumn{7}{|c|}{ TENSILE STRENGTH RATIO CALCULATION SHEET } \\
\hline Sample Identification & 1 & 2 & 3 & 4 & 5 & 6 \\
\hline Diameter (mm) & 150 & 150 & 150 & 150 & 150 & 150 \\
\hline Thickness (mm) & 95 & 95 & 95 & 95 & 95 & 95 \\
\hline Dry Mass in Air (gm) & 3980 & 3985 & 3994.7 & 3998.6 & 3981.6 & 4000 \\
\hline SSD Mass (gm) & 4012 & 4013.5 & 4022 & 4011.2 & 4016.5 & 4019.6 \\
\hline Mass in Water (gm) & 2400 & 2402 & 2401.6 & 2395.2 & 2405.6 & 2401.9 \\
\hline Volume (cc) & 1612 & 1611.5 & 1620.4 & 1616 & 1610.9 & 1617.7 \\
\hline Bulk Specific Gravity & 2.469 & 2.473 & 2.465 & 2.474 & 2.472 & 2.473 \\
\hline Maximum Specific Gravity & 2.622 & 2.622 & 2.622 & 2.622 & 2.622 & 2.622 \\
\hline \% Air Voids & 5.84 & 5.69 & 5.98 & 5.63 & 5.73 & 5.70 \\
\hline Volume of Air Voids & 94.07 & 91.67 & 96.87 & 90.98 & 92.36 & 92.15 \\
\hline Load (N) & 12513 & 12987 & 11989 & & & \\
\hline Saturated (min) & & & & & & \\
\hline Thickness (mm) & & & & 94.5 & 95.1 & 94.7 \\
\hline SSD Mass (gm) & & & & 4065 & 4048.7 & 4069.9 \\
\hline Volume of Absorbed water & & & & 66.4 & 67.1 & 69.9 \\
\hline \% Saturation & & & & 72.98 & 72.65 & 75.86 \\
\hline Load (N) & & & & 10529 & 10879 & 10240 \\
\hline Dry Strength & 559.30 & 580.49 & 535.88 & & & \\
\hline Wet Strength & & & & 473.11 & 485.76 & 459.15 \\
\hline TSR & 84.59 & 83.68 & 85.68 & & & \\
\hline Average TSR & 84.65 & & & & & \\
\hline
\end{tabular}

Table C.4 Draindown result for SMA Mix design No.2

\begin{tabular}{||l|c|c|c|}
\hline \multicolumn{4}{|c|}{ SMA Drain Down Test Report } \\
\hline Before Oven Treatment & Test No.1 & Test No.2 & \\
\hline Mass of Paper plate to the nearest 0.1g & 1023.50 & 1015.7 & \\
\hline After Oven treatment one hour & 1023.50 & 1015.7 & \\
\hline Mass of Paper plate to the nearest 0.1g & 0.00 & 0.00 & \\
\hline Drain down (\%) & 0.00 & 0.00 & \\
\hline Average Drain Down (\%) & \multicolumn{3}{|c|}{0.00} \\
\hline \hline
\end{tabular}


Table C.5 TSR SMA Mix design No.3

\begin{tabular}{||l|c|c|c|c|c|c||}
\hline \multicolumn{7}{|c|}{ TENSILE STRENGTH RATIO CALCULATION SHEET } \\
\hline Sample Identification & 1 & 2 & 3 & 4 & 5 & 6 \\
\hline Diameter (mm) & 150 & 150 & 150 & 150 & 150 & 150 \\
\hline Thickness (mm) & 95 & 95 & 95 & 95 & 95 & 95 \\
\hline Dry Mass in Air (gm) & 4012.1 & 3998.4 & 4002.5 & 3996.7 & 4002.2 & 4009.7 \\
\hline SSD Mass (gm) & 4030.5 & 4022.5 & 4031.8 & 4019.8 & 4028.6 & 4033.1 \\
\hline Mass in Water (gm) & 2401 & 2399 & 2410 & 2397.4 & 2405.6 & 2404.6 \\
\hline Volume (cc) & 1629.5 & 1623.5 & 1621.8 & 1622.4 & 1623 & 1628.5 \\
\hline Bulk Specific Gravity & 2.462 & 2.463 & 2.468 & 2.463 & 2.466 & 2.462 \\
\hline Maximum Specific Gravity & 2.618 & 2.618 & 2.618 & 2.618 & 2.618 & 2.618 \\
\hline$\%$ Air Voids & 5.95 & 5.93 & 5.73 & 5.90 & 5.81 & 5.95 \\
\hline Volume of Air Voids & 96.99 & 96.23 & 92.96 & 95.78 & 94.28 & 96.91 \\
\hline Load (N) & 13529 & 13125 & 13759 & & & \\
\hline Saturated (min) & & & & & & \\
\hline Thickness (mm) & & & & 95 & 94.9 & 94.8 \\
\hline SSD Mass (gm) & & & & 4069.1 & 4071.5 & 4079.8 \\
\hline Volume of Absorbed water & & & & 72.4 & 69.3 & 70.1 \\
\hline$\%$ Saturation & & & & 75.59 & 73.51 & 72.33 \\
\hline Load (N) & & & & 11348 & 11780 & 11647 \\
\hline Dry Strength & 604.716 & 586.658 & 614.996 & & & \\
\hline Wet Strength & & & 507.230 & 527.094 & 521.693 \\
\hline TSR & 83.88 & 89.85 & 84.83 & & & \\
\hline Average TSR & & & & & \\
\hline \hline
\end{tabular}

Table C.6 Draindown result for SMA Mix design No.3

\begin{tabular}{|c|c|c|}
\hline \multicolumn{3}{|c|}{ SMA Drain Down Test Report } \\
\hline Before Oven Treatment & Test No.1 & Test No.2 \\
\hline Mass of Paper plate to the nearest $0.1 \mathrm{~g}$ & 1023.50 & 1015.7 \\
\hline After Oven treatment one hour & 1023.50 & 1015.7 \\
\hline Mass of Paper plate to the nearest $0.1 \mathrm{~g}$ & 0.00 & 0.00 \\
\hline Drain down $(\%)$ & 0.00 & 0.00 \\
\hline Average Drain Down (\%) & \multicolumn{2}{|c|}{0.00} \\
\hline
\end{tabular}


Table C.7 TSR result for SMA Mix design No.4

\begin{tabular}{|l|c|c|c|c|c|c||}
\hline \multicolumn{7}{|c|}{ TENSILE STRENGTH RATIO CALCULATION SHEET } \\
\hline Sample Identification & 1 & 2 & 3 & 4 & 5 & 6 \\
\hline Diameter (mm) & 150 & 150 & 150 & 150 & 150 & 150 \\
\hline Thickness (mm) & 95 & 95 & 95 & 95 & 95 & 95 \\
\hline Dry Mass in Air (gm) & 4010 & 3998.7 & 4005 & 3990 & 3989.4 & 4001.6 \\
\hline SSD Mass (gm) & 4039 & 4022.6 & 4031 & 4011.9 & 4020.2 & 4023.5 \\
\hline Mass in Water (gm) & 2406.6 & 2400 & 2404.3 & 2388.4 & 2401.6 & 2399.5 \\
\hline Volume (cc) & 1632.4 & 1622.6 & 1626.7 & 1623.5 & 1618.6 & 1624 \\
\hline Bulk Specific Gravity & 2.457 & 2.464 & 2.462 & 2.458 & 2.465 & 2.464 \\
\hline Maximum Specific Gravity & 2.617 & 2.617 & 2.617 & 2.617 & 2.617 & 2.617 \\
\hline \% Air Voids & 6.13 & 5.83 & 5.92 & 6.09 & 5.82 & 5.84 \\
\hline Volume of Air Voids & 100.11 & 94.63 & 96.32 & 98.85 & 94.18 & 94.92 \\
\hline Load (N) & 10517 & 11512 & 10989 & & & \\
\hline Saturated (min) & & & & & & \\
\hline Thickness (mm) & & & & 94.9 & 95 & 94.7 \\
\hline SSD Mass (gm) & & & & 4065.2 & 4055.8 & 4068.5 \\
\hline Volume of Absorbed water & & & & 75.2 & 66.4 & 66.9 \\
\hline \% Saturation & & & & 76.07 & 70.50 & 70.48 \\
\hline Load (N) & & & & 8543 & 9425 & 8945 \\
\hline Dry Strength & 470.09 & 514.56 & 491.18 & & & \\
\hline Wet Strength & & & & 382.26 & 421.28 & 401.09 \\
\hline TSR & 81.32 & 81.87 & 81.66 & & & \\
\hline Average TSR & & & & & \\
\hline \hline
\end{tabular}

Table C.8 Draindown result for SMA Mix design No.4

\begin{tabular}{||l|c|c|c|}
\hline \multicolumn{4}{|c|}{ SMA Drain Down Test Report } \\
\hline Before Oven Treatment & Test No.1 & Test No.2 & \\
\hline Mass of Paper plate to the nearest 0.1g & 1023.50 & 1015.7 & \\
\hline After Oven treatment one hour & 1023.50 & 1015.7 & \\
\hline Mass of Paper plate to the nearest 0.1g & 0.00 & 0.00 & \\
\hline Drain down (\%) & 0.00 & 0.00 & \\
\hline Average Drain Down (\%) & \multicolumn{3}{|c|}{0.00} \\
\hline
\end{tabular}


Table C.9 TSR Result for SMA Mix design No.5

\begin{tabular}{||l|c|c|c|c|c|c||}
\hline \multicolumn{7}{|c|}{ TENSILE STRENGTH RATIO CALCULATION SHEET } \\
\hline Sample Identification & 1 & 2 & 3 & 4 & 5 & 6 \\
\hline Diameter (mm) & 150 & 150 & 150 & 150 & 150 & 150 \\
\hline Thickness (mm) & 95 & 95 & 95 & 95 & 95 & 95 \\
\hline Dry Mass in Air (gm) & 3980.7 & 3975.8 & 3986.2 & 3990.7 & 3984.6 & 3979.1 \\
\hline SSD Mass (gm) & 4010.1 & 4015.3 & 4005.8 & 4011.9 & 4009.1 & 4015.3 \\
\hline Mass in Water (gm) & 2395.6 & 2390.8 & 2380.5 & 2388.9 & 2385.2 & 2398.3 \\
\hline Volume (cc) & 1614.5 & 1624.5 & 1625.3 & 1623 & 1623.9 & 1617 \\
\hline Bulk Specific Gravity & 2.466 & 2.447 & 2.453 & 2.459 & 2.454 & 2.461 \\
\hline Maximum Specific Gravity & 2.622 & 2.622 & 2.622 & 2.622 & 2.622 & 2.622 \\
\hline$\%$ Air Voids & 5.97 & 6.66 & 6.46 & 6.22 & 6.42 & 6.15 \\
\hline Volume of Air Voids & 96.31 & 108.18 & 105.01 & 100.99 & 104.22 & 99.42 \\
\hline Load (N) & 25100 & 25890 & 24955 & & & \\
\hline Saturated (min) & & & & & & \\
\hline Thickness (mm) & & & & 95.1 & 94.9 & 95.2 \\
\hline SSD Mass (gm) & & & & 4066.6 & 4061.2 & 4055.6 \\
\hline Volume of Absorbed water & & & & 75.9 & 76.6 & 76.5 \\
\hline$\%$ Saturation & & & & 75.15 & 73.50 & 76.95 \\
\hline Load (N) & 1121.91 & 1157.22 & 1115.43 & & & \\
\hline Dry Strength & & & & 752.01 & 755.02 & 752.87 \\
\hline Wet Strength & 66.59 & & & & & \\
\hline TSR & & & & & & \\
\hline Average TSR & & & & & & \\
\hline
\end{tabular}

Table C.10 Drain down result for SMA Mix design No.5

\begin{tabular}{||l|c|c|}
\hline \multicolumn{3}{|c|}{ SMA Drain Down Test Report } \\
\hline Before Oven Treatment & Test No.1 & Test No.2 \\
\hline Mass of Paper plate to the nearest 0.1g & 219.80 & 223.2 \\
\hline After Oven treatment one hour & 219.80 & 223.2 \\
\hline Mass of Paper plate to the nearest 0.1g & 0.00 & 0.00 \\
\hline Drain down percentage & 0.00 & 0.00 \\
\hline Average Drain Down & \multicolumn{3}{|c|}{0.00} \\
\hline
\end{tabular}

